Hydrology of the

Price River Basin, Utah

with emphasis on

Selected Coal-Field Areas

United States Geological Survey

Water-Supply

Paper 2246

Prepared in cooperation with the U.S. Bureau of Land Management

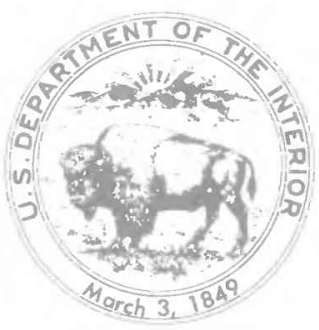




\title{
Hydrology of the \\ Price River Basin, Utah \\ with emphasis on \\ Selected Coal-Field Areas
}

\author{
By K. M. Waddell, J. E. Dodge, \\ D. W. Darby, and S. M. Theobald
}

Prepared in cooperation with the

U.S. Bureau of Land Management 


\title{
DEPARTMENT OF THE INTERIOR DONALD PAUL HODEL, Secretary
}

\author{
U.S GEOLOGICAL SURVEY \\ Dallas L. Peck, Director
}

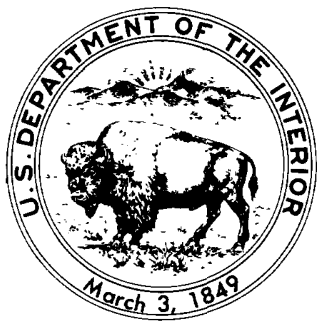

Library of Congress Cataloging in Publication Data

Hydrology of the Price River Basin, Utah with emphasis on selected coal-field areas.

(United States Geological Survey water-supply paper 2246)

"Prepared in cooperation with the U.S. Bureau of Land Management."

Supt. of Docs. no.: I 19.13:2246

1. Water, Underground-Utah-Price River Watershed. I. Waddell, K. M. (Kidd M.), 1937- . II. United States. Bureau of Land Management. III. Series. IV. Series: U.S. Geological Survey water-supply paper 2246.

GB1025.U8H93 1986

$551.49^{\prime} 09792^{\prime} 57$

83-600322

For sale by the Branch of Distribution

U.S. Geological Survey

604 South Pickett Street

Alexandria, VA 22304 


\title{
CONTENTS
}

\author{
Abstract 1 \\ Introduction 1 \\ Need for study 1 \\ Objectives and approach $\mathbf{3}$ \\ Previous studies $\mathbf{3}$ \\ Acknowledgments 3 \\ Physiography and drainage $\mathbf{3}$ \\ Precipitation 3 \\ Geologic description 4
}

Surface water $\mathbf{4}$

Streamflow and average discharge 4

Runoff and evapotranspiration 4

Flood characteristics 4

Quality of surface water 5

Chemical quality $\mathbf{5}$

Streams 5

Mud Creek drainage basin 6

Soldier Creek drainage basin 7

Trace metals 7

Scofield Reservoir 7

Sediment in streams and Scofield Reservoir

Bed material $\mathbf{1 3}$

Particle size 13

Mineralogy 14

Deposition in Scofield Reservoir 14

Thunderstorm runoff $\mathbf{1 9}$

Benthic invertebrates 21

Ground water $\mathbf{2 4}$

Discharge from springs $\mathbf{2 4}$

Beaver Creek drainage basin $\mathbf{2 4}$

Mud Creek drainage basin $\mathbf{2 6}$

Soldier Creek area $\mathbf{2 6}$

Discharge from mines $\mathbf{2 8}$

Ground water-surface water relationships

Recession curves $\mathbf{2 8}$

Chemical quality 29

Geochemical relationships $\mathbf{3 1}$

Trace metals $\mathbf{3 3}$

Hydrology of the Mud Creek drainage basin $\mathbf{3 5}$

Precipitation and streamflow 35

Ground water $\mathbf{3 5}$

Water levels $\mathbf{3 5}$

Discharge to streams $\mathbf{3 5}$

Hydrology of the Soldier Creek area $\mathbf{3 8}$

Precipitation and streamflow $\mathbf{3 8}$

Ground water $\mathbf{4 1}$

Hydraulic properties of the ground-water reservoir $\mathbf{4 1}$

Water levels $\mathbf{4 1}$

Recharge to the Flagstaff Limestone

Discharge to streams 
Detecting effects of mining on the hydrology $\mathbf{4 6}$

Interbasin diversions $\mathbf{4 6}$

Redistribution of flow $\mathbf{4 7}$

Additional studies $\mathbf{4 8}$

Summary 49

References cited $\mathbf{5 0}$

PLATE

1. Maps showing geology, average annual precipitation, concentration of dissolved solids in ground water, and data collection sites in the Price River basin, Utah (in pocket)

\section{FIGURES}

1. Map showing location of Price River basin 2

2. Map showing seepage-study sites and quality of ground and surface water in the Mud Creek drainage basin, 1979-80 8

3. Graph showing relationship between the concentration of dissolved solids and discharge for selected streams in the Price River basin, 1980 water year $\mathbf{1 0}$

4. Map showing location of water-quality and core-sampling sites in the Scofield Reservoir area 12

5. Photographs of bed material, and graphs showing particle-size distribution for sites on Fish, Mud, and Soldier Creeks, 197916

6-11. Graphs showing:

6. Mineralogic composition of bed material at sites in the Soldier Creek area and Mud Creek drainage basin, 1976 and $1979 \quad 18$

7. Relationship of relative lead-210 activity and depth of sediment in Scofield Reservoir, $1980 \quad \mathbf{2 0}$

8. Vertical distribution of coal in sediment cores from Scofield Reservoir, 198021

9. Relationship of concentration of suspended sediment and water discharge during thunderstorm runoff at gaging station on Soldier Creek (site S59), July 19, $1979 \quad 22$

10. Relationship of benthic-invertebrate diversity and particle size for selected sites, $1979 \quad \mathbf{2 2}$

11. Range of benthic-invertebrate diversity index at selected sites, 1979-80 23

12. Recession hydrographs of selected springs and a well in the Beaver and Mud Creek drainages and the Soldier Creek area, $1980 \quad \mathbf{2 6}$

13. Hydrographs of streams in the Soldier Creek area and separation of base flow from the Flagstaff Limestone and the Blackhhawk Formation, Castlegate Sandstone, and Price River and North Horn Formations 30

14. Graph showing relationship between the discharge of Soldier Creek and the concentration of dissolved chemical constituents in Soldier Creek and in ground water, 1979-80 32

15. Map showing geology, data-collection sites for ground water, and potentiometric surface for the Star Point Sandstone in the Mud Creek drainage basin, $1980 \quad 36$

16. Graph showing profile of Mud Creek and streamflow hydrographs for October 12, 1979, and September 5, $1980 \mathbf{3 8}$

17. Graph showing profile of Eccles Canyon and hydrographs of streamflow on October 11, 1979, and September 5, 1980 
18. Hydrographs showing decline of fluid level after perforating the casings of five wells in the Soldier Creek area $\mathbf{4 0}$

19. Generalized geologic section showing water levels in wells and a mine in the Soldier Creek area in the Book Cliffs, $1980 \mathbf{4 2}$

20-24. Graphs showing:

20. Profile of Pine Canyon and changes in streamflow on October 10, 1979, September 4, 1980, and October 11, 198044

21. Profile of Soldier Creek and changes in streamflow on October 10, 1979, and September 5, $1980 \mathbf{4 5}$

22. Ratio of discharge at selected sites to discharge at mouth of Mud Creek (site S36) on October 12, 1979, August 15, 1980, September 5, 1980, and October 15, $1980 \quad 47$

23. Ratio of discharge at selected sites to discharge at mouth of Eccles Canyon (site S29) on October 11, 1979, and September 5, $1980 \quad 48$

24. Ratio of discharge at selected sites to discharge at mouth of Soldier Creek (site S59) on August 2, 1979, October 11, 1979, and September 4, $1980 \quad 48$

\section{TABLES}

1. Published stream-gaging records and ranges of annual discharge, 1931-80 water years 5

2. Water budget for selected basins, 1971-80 water years 5

3. Compilation of selected basin characteristics and data used for estimating evapotranspiration in the Price River basin 6

4. Range of concentration of dissolved trace elements for selected streams, October 1, 1979-August 31, $1980 \quad \mathbf{1 1}$

5. Selected characteristics of springs, a well, and a mine that were monitored during $1980 \quad 25$

6. Discharge of water from coal mines $\mathbf{2 8}$

7. Recession characteristics for selected streams in the Book Cliffs, $1980 \mathbf{3 1}$

8. Summary of solubility indexes for ground water $\mathbf{3 3}$

9. Chemical analyses for dissolved metals in water from selected springs, mines, and a well in the Price River basin $\mathbf{3 4}$

10. Estimated ground-water and surface runoff from Coal, Soldier, and Dugout Creeks during the 1980 water year $\mathbf{3 8}$

11. Discharge of water from springs and seepage gains in Pine Canyon used to estimate recharge to the Flagstaff Limestone, 1980 water year $\mathbf{4 3}$ 


\section{Conversion Factors and Related Information}

For use of readers who prefer to use metric units, conversion factors for terms used in this report are listed below:

\begin{tabular}{lcl}
\hline \multicolumn{1}{c}{ Multiply } & By & \multicolumn{1}{c}{ To obtain } \\
\hline Acre & 0.004047 & Square kilometer \\
Acre-foot & 0.001233 & Cubic hectometer \\
Cubic foot & 0.02832 & Cubic meter \\
Cubic foot per second & 0.02832 & Cubic meter per second \\
Foot & 0.3048 & Meter \\
Foot per mile & 0.1894 & Meter per kilometer \\
Foot squared per day & 0.0929 & Square meter per day \\
Gallon & 3.785 & Liter \\
& 0.003785 & Cubic meter \\
Gallon per minute & 0.003785 & Cubic meter per minute \\
Inch & 25.40 & Millimeter \\
& 2.540 & Centimeter \\
Mile & 1.609 & Kilometer \\
Pound & 453.6 & Gram \\
Square foot & 0.0929 & Square meter \\
Square mile & 2.590 & Square kilometer \\
Ton, short & 0.9072 & Metric ton \\
& 0.9072 & Megagram \\
\hline
\end{tabular}

Chemical concentration and water temperature are given only in metric units. Chemical concentration is given in milligrams per liter or micrograms per liter. Milligrams per liter is a unit expressing the concentration of chemical constituents in solution as weight (milligrams) of solute per unit volume (liter) of water. One thousand micrograms per liter is equivalent to 1 milligram per liter. For concentrations less than 7.000 milligrams per liter, the numerical value is about the same as for concentrations in parts per million.

Chemical concentration in terms of ionic interacting values is given in milliequivalents per liter. Milliequivalents per liter is numerically equal to equivalents per million.

Water temperature is given in degrees Celsius $\left({ }^{\circ} \mathrm{C}\right)$, which can be converted to degrees Fahrenheit $\left({ }^{\circ} \mathrm{F}\right)$ by the following equation:

$$
{ }^{\circ} \mathrm{F}=1.8\left({ }^{\circ} \mathrm{C}\right)+32 .
$$

National Geodetic Vertical Datum of 1929 (NGVD of 1929): is a geodetic datum derived from a general adjustment of the first-order level nets of the United States and Canada. It was formerly called mean sea level. NGVD of 1929 is referred to as sea level in this report. 


\title{
Hydrology of the Price River Basin, Utah, with Emphasis on Selected Coal-Field Areas
}

\author{
By K.M. Waddell, J.E. Dodge, D.W. Darby, and S.M. Theobald
}

\begin{abstract}
Data obtained during a hydrologic study of the Price River basin, Utah, are used to describe seasonal variations of flow of springs, relation between ground water and surface water, hydraulic properties of the ground-water reservoir ground-water recharge and discharge, flood characteristics of streams, mineralogic composition and depositional rates of sediments, nutrient and inorganic loading in streams and Scofield Reservoir, and water budgets for selected basins. Additional study and monitoring are needed to detect possible hydrologic changes caused by coal mining.

Much of the ground-water discharge from the Star Point Sandstone in the Mesaverde Group in the Wasatch Plateau occurs along faults. In the Book Cliffs, where faulting is less extensive, most of the ground-water discharge is from the Flagstaff Limestone. The Flagstaff Limestone is greatly diffusive, has a small storage coefficient, and contains water which is perched.
\end{abstract}

Springs issuing from the Star Point Sandstone in the Mud Creek drainage (Wasatch Plateau) had recession indexes greater than 365 days per log cycle. Springs issuing at higher altitudes from the Colton Formation and the Flagstaff Limestone in the Soldier Creek area (Book Cliffs) have great seasonal variability, with recession indexes ranging from 24 to 115 days per log cycle. Estimated transmissivities in the Soldier Creek area ranged from 0.003 foot squared per day in the lower part of the Castlegate Sandstone to 0.07 foot squared per day in the Price River Formation.

Seepage from the Star Point Sandstone is the major contributor to base flow of the stream in Eccles Canyon (Wasatch Plateau). Gains of as much as 230 gallons per minute occurred near a fault zone which crosses Eccles Canyon at the junction with South Fork Canyon.

The potentiometric surface of water in the Blackhawk Formation in the Wasatch Plateau (Mud Creek drainage) and the Book Cliffs (Soldier Creek area) generallv is above the coal zones, and dewatering will be necessary in most places during mining. The total reported mine discharge during 1980 was about 2,800 acre-feet.

During the 1980 water year, ground-water discharge from the Flagstaff Limestone contributed about 4,400 acre-feet, or 41 percent of the combined streamflow of Coal, Soldier, and Dugout Creeks. Discharge from the Blackhawk and other formations contributed about 2,200 acrefeet, or 21 percent of the streamflow. The recharge to a 4,020-acre outcrop of the Flagstaff Limestone in the Soldier Creek area was determined from measurements of the discharge of springs and seepage gains in streams. The estimated recharge was 2 inches per year, or 12 percent of the April 1 snowpack, or 9 percent of the precipitation during 1980.
Benthic-diversity indexes at streams in the Book Cliffs and Wasatch Plateau are related to the size of the bed material. The Shannon-Weiner diversity index for five sites in the Mud Creek drainage ranged from 1.57 to 4.20 during four sampling periods in 1979-80. In the Soldier Creek drainage, the diversity index for four sampling sites ranged from 0.8 to 2.3 during three sampling periods in 1979-80.

Sediment deposition in Scofield Reservoir during 1943-79 was estimated to be 3,000 acre-feet but most of the coal deposition in the reservoir occurred prior to about 1950. An anaerobic zone develops in the reservoir during the summer, but water in the reservoir completely mixes during late summer or early fall.

\section{INTRODUCTION}

\section{Need for study}

Underground coal mining is increasing in the Price River basin in east central Utah (fig. 1) in response to the national demand for energy fuels. Several companies are now developing new mines or expanding current operations in both the Wasatch Plateau and Book Cliffs and coal production in the basin is expected to double from the current rate of about 5.3 million tons per year (1980) within the next 10 years (Gordon Whitney, U.S. Geological Survey, oral commun., May 15, 1981). In Utah, coal production is expected to increase form the current rate of 13.5 million tons per year (1980) to between 19 and 24 million tons per year by 1990 (U.S. Geological Survey, 1979). An increase in population undoubtedly will be associated with this increased production. Underground mining in part of the study area is expected to affect the quality of the water and existing groundwater and streamflow conditions, which in turn may affect pre-existing water rights on springs and streams.

The U.S. Geological survey in cooperation with the U.S. Bureau of Land Management conducted a study from October 1978 to September 1980 to assess the hydrology of the Price River basin with emphasis on coal-field areas. Because of the size of the basin (about $1,900 \mathrm{mi}^{2}$ ), two areas were studied in more detail than the remainder of the basin. Those areas were the Mud Creek drainage upstream from Scofield Reservoir in the Wasatch Plateau and the Soldier Creek area in the Book Cliffs. 


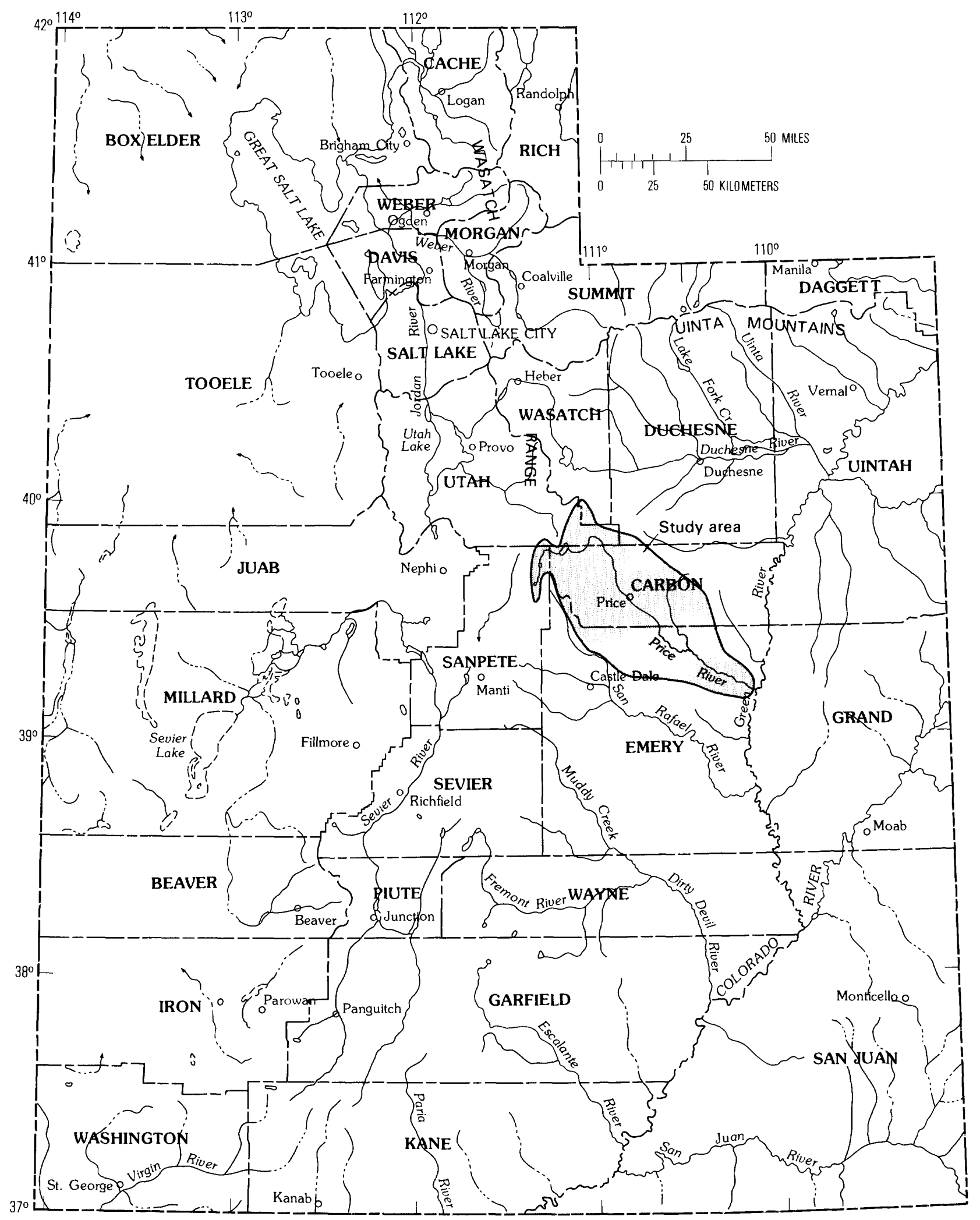

Figure 1. Location of Price River basin. 


\section{Objectives and Approach}

The objectives of the study were to : (1) describe the hydrology of the basin and selected coal-field areas, (2) establish relationships between hydrologic properties and characteristics that can be used as a basis for distinguishing between natural and man-caused effects, and (3) determine monitoring programs and additional studies that might be needed to document the effects of coal mining.

Data collection during 1978-80 included:

1. Measuring of base flow of selected stream reaches;

2. Inventorying springs, including measurements of discharge, temperature, and specific conductance, and determination of geologic source;

3. Monitoring of discharges of selected springs following the snowmelt period;

4. Sampling of ground and surface water for chemical analyses:

5. Inventorying wells and measuring water levels;

6. Collecting water-quality and bathymetric data in Scofield Reservoir to determine nutrient balance and sediment deposition;

7. Dating of sediment cores from Scofield Reservoir using lead-210 and cesium- 137 isotopes to determine rates of sediment deposition:

8. Determining distribution of particle size in streambed sediments using photogrammetric techniques;

9. Determining mineralogy of streambed sediments; and

10. Calculating diversity of benthic invertebrates.

This report contains information about data sites referred to in the text; all data collected during 1978-80 are given in a separate report by Waddell and others (1982).

\section{Previous Studies}

Several previous hydrologic studies included all or parts of the Price River basin. Cordova (1963) studied the ground-water resources of a part of the headwaters area and included a description of aquifers. Mundorff (1972) investigated the water quality of streams in the Price River basin, including seasonal variations. Waddell and others (1981) conducted a reconnaissance of the hydrology of the Wasatch Plateau-Book Cliffs coal-field areas and compiled data bases for several hydrologic and climatic properties and characteristics, and determined hydrologic-monitoring needs. Lines and Plantz (1981) presented data for selected streams that were collected as part of the U.S. Geological Survey's coal-hydrology monitoring program that began in 1978.

\section{Acknowledgments}

Appreciation is extended to property owners and coal companies for allowing access to their land and mines and for supplying valuable hydrologic data. Special thanks is extended to Paul Anderson of Eureka Energy Co. for supplying considerable hydrologic data as well as assisting with field operations, including testing of a Eureka Energy Co. well. Treavor Whiteside of Valley Camp Coal Co. arranged for an escort into the Valley Camp mines and assisted with locating property owners. Jack and George Otani assisted with installation of equipment and location of springs and provided records of spring discharge.

\section{Physiography and Drainage}

The Price River basin includes about 1,900 square miles of valley and mountainous areas in east-central Utah (plate 1.) The coal fields lie within the mountainous areas, the drainage of which includes about 800 square miles of the basin. The drainage divide of the Book Cliffs forms the northern and eastern boundaries, and the divide of the Wasatch Plateau forms the western boundary of the study area. The canyon of the Price River is a physiographic break between the Wasatch Plateau and the Book Cliffs.

The largest stream in the study area is the Price River, and its major headwater tributary is Fish Creek. The Price River proper begins downstream from Scofield Reservoir. The largest stream in the Book Cliffs is Willow Creek, which has a drainage area of 81 square miles.

The Wasatch Plateau ranges from about 9,000 to 12,000 feet above sea level and is approximately 4,000 to 7,000 feet above the lowlands to the east and west. The Book Cliffs range from about 7,000 to 10,000 feet above sea level and are about 2,000 to 5,000 feet above the lowlands to the south and west.

\section{Precipitation}

The maximum average annual precipitation in the study area exceeds 30 inches at the higher altitudes of the Wasatch Plateau as compared to a maximum of about 20 inches in the Book Cliffs (plate 1). The precipitation varies across the study area, generally reflecting variation in altitude. In the Wasatch Plateau, about 70 percent of the precipitation falls during October-April, whereas in the Book Cliffs about 60 percent falls during the same period. 
During the $1979-80$ water years ${ }^{1}$, when most of the data for this study were obtained, precipitation was greater than normal. Comparison of precipitation between two long-term stations, Hiawatha in the Wasatch Plateau and Sunnyside in the Book Cliffs, indicates that during water year 1979, precipitation was about 25 percent greater than normal at Hiawatha and about 15 percent greater than normal at Sunnyside. During water year 1980 , precipitation was about 35 percent greater than normal at Hiawatha and 45 percent greater than normal at Sunnyside.

\section{Geologic Description}

The consolidated-rock formations that crop out in the study area are of Triassic(?) to Tertiary age (plate 1). The exposed rocks include limestone, sandstone, mudstone, siltstone, shale, conglomerate, and coal. The principal coal-producing formations are of Cretaceous age, and the Blackhawk Formation of the Mesaverde Group contains the most important coal deposit in Utah. The Blackhawk is composed of sandstone, shale, and coal. Coal beds as thick as 20 feet are found locally in the lower part of the formation. The North Horn Formation and Flagstaff Limestone of Tertiary and Cretaceous age and younger formations that overlie the Mesaverde Group do not contain coal. However, they yield large quantities of freshwater through numerous springs and seeps that flow into the headwaters of streams at the higher altitude of the Wasatch Plateau and Book Cliffs.

\section{SURFACE WATER}

\section{Streamflow and Average Discharge}

Streamflow records for varying times have been obtained since the 1931 water year at 28 stations on 17 streams (table 1 ) in the Price River basin. Nine of these stations were installed during 1978-79 as part of the U.S. Geological Survey's coal-hydrology monitoring program (Lines and Plantz, 1981). During the 1980 water year, as part of this study, continuous-streamflow data were collected on Pondtown Creek (site S4) and the Price River near Scofield (site S37.) (See table 1 and fig.1.)

The extreme annual discharges for the period of record for each station are included in table 1 . The minimum annual discharge for many of the stations occurred during the 1977 water year, and the maximum occurred at many stations during the 1980 water year.

'A water year extends from October 1 to September 30 and is designated by the year in which it ends.
Streamflow in the study area was about or greater than average at most stations during the 1979-80 water years. The flow of Fish Creek in the Wasatch Plateau (site S2) was about 97 percent of the 1971-80 average during 1979 and about 170 percent of the 1971-80 average during 1980. The flow of Willow creek in the Book Cliffs (site S37.3) was about 250 percent of the 1971-80 average during 1979 and about 196 percent of the average during 1980.

\section{Runoff and Evapotranspiration}

Water budgets for four subbasins in the Wasatch Plateau and Book Cliffs were compiled for 1971-80 water years (table 2). The volume of Precipitation that fell on each drainage basin was computed from a map of Utah showing normal annual precipitation for 1931-60 (U.S. Weather Bureau, 1963). Although the average streamflow was computed for a different period, comparison of the precipitation records at two (climatic) sites for 1971-80 and 1931-60 indicated that there was so significant difference in the averages for the two periods.

By assuming that the change in ground-water storage $(\Delta S)$ and the underflow (or subsurface flow) $(U)$ at the gaging station of each drainage basin both are negligible, the net loss by evapotranspiration $(E T)$ can be computed from the equation $E T=P-R \pm \Delta S-U$. where $P$ is the mean annual precipitation over the basin and $R$ is the gaged streamflow at the gaging station. Evapotranspiration from the four basins ranged from 16 to 21 inches and averaged 19 inches per year.

\section{Flood Characteristics}

The U.S. Office of Surface Mining, Reclamation, and Enforcement has established regulations that require culverts, diversion structures, settling ponds, and other structures associated with mining activities be designed for floods of particular magnitude. Attempts were made to determine flood characteristics for selected stream sites in the study area from empirical relationships among drainage area, mean annual precipitation, basin slope, and rainfall intensity.

The standard errors of the predictive equations developed in this study were not within acceptable limits. A separate study that was conducted to determine flood characteristics in Utah included equations that can be used for sites in the Price River basin (Thomas and Lindskov, 1983). Basin characteristics used as independent variables in the equations developed by Thomas and Lindskov were tabulated for selected sites in the Price River basin (table 3). Thus, by using these equations, one may compute specific flood characteris- 
Table 1. Published stream-gaging records and ranges of annual discharge, 1931-80 water years

Site No.: See figure 1 for location.

Data source: 1, 1931-80, U.S. Geological Survey annual reports on stream measurements issued as Water-Supply Papers, Surface Water Supply of the United States, Colorado River Basin: 2, 1961-64, U.S. Geological Survey annual reports of Surface-Water Records of Utah: 3, 1965-74, U.S. Geological Survey annual reports of Water-Resources Data for Utah, Part 1, Surface -Water Records; 4, 1975-80, U.S. Geological Survey annual reports of Water-Resources Data for Utah.

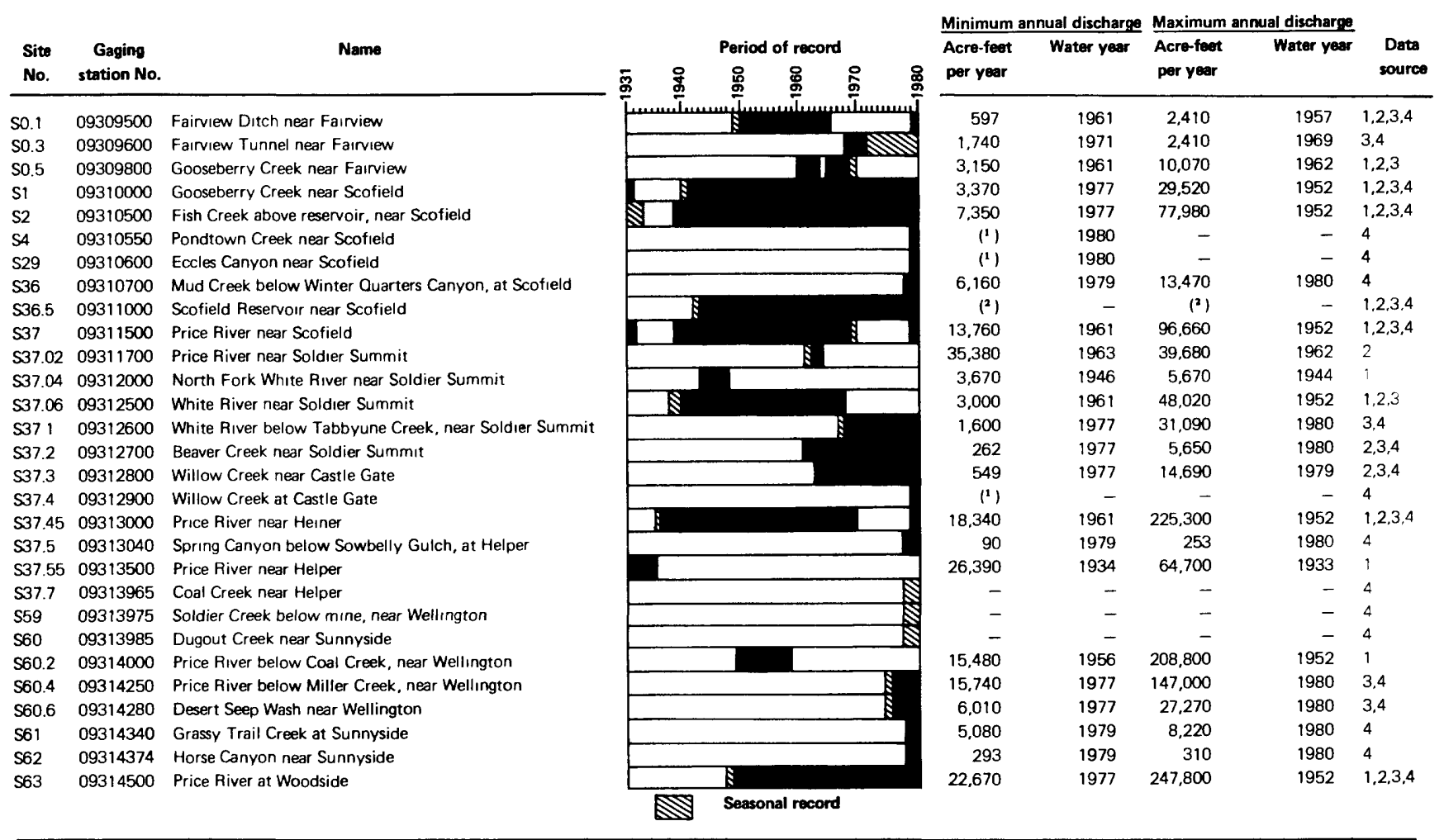

1 Only 1 year of record available.

2 Reservorr contents.

Table 2. Water budget for selected basins, 1971-80 water years

Site No.: See figure 1 for location.

Evapotranspiration: Computed from relationship; evapotranspiration is equal to average annual precipitation minus average annual streamflow.

\begin{tabular}{|c|c|c|c|c|c|c|}
\hline \multirow{2}{*}{$\begin{array}{l}\text { Site } \\
\text { No. }\end{array}$} & \multirow[b]{2}{*}{ Stream } & \multirow{2}{*}{$\begin{array}{c}\text { Drainage } \\
\text { area } \\
\text { (acres) }\end{array}$} & \multirow{2}{*}{$\begin{array}{c}\text { Average } \\
\text { annual } \\
\text { precipitation } \\
\text { (inches) }\end{array}$} & \multicolumn{2}{|c|}{$\begin{array}{c}\text { Average annual } \\
\text { streamflow }\end{array}$} & \multirow[b]{2}{*}{$\begin{array}{l}\text { Evapotranspiration } \\
\text { (inches) }\end{array}$} \\
\hline & & & & Acre-feet & Inches & \\
\hline S2 & Fish Creek & 38,500 & 32 & 36.430 & 11 & 21 \\
\hline$S 371$ & White River & 48,400 & 22 & 20,100 & 5 & 17 \\
\hline$\$ 372$ & Beaver Creek & 16,700 & 23 & 2,860 & 2 & 21 \\
\hline \multirow[t]{2}{*}{$\$ 373$} & Willow Creek & 40,200 & 18 & 5,900 & 2 & 16 \\
\hline & & & & & & Average 19 \\
\hline
\end{tabular}

tics for the sites given in table 3. Most of the selected sites are either near the base of the Blackhawk Formation or in an area of active or planned coal mining (fig. 1).

\section{Quality of Surface Water}

\section{Chemical Quality \\ Streams}

Considerable data for defining the chemical quality of water have been collected on streams in the Price River basin since 1969. Mundorff (1972) described the inorganic chemistry of the water in relation to geology and the effects of water use, including irrigation. Waddell and others (1981) prepared maps showing the range of dissolved solids and inorganic chemical composition as related to the geology. Lines and Plantz (1981) presented a summary of water-quality data for stream sites that began operation in 1978 as part of the U.S.Geological Survey's coal-hydrology monitoring program. Their data included inorganic, organic, and biologic constituents. Ponce and Hawkins (1978) studied the mechanics of salt pickup from overland flow on the Mancos Shale.

In this study, emphasis was placed on nutrients and inorganic constituents, including trace metals and major ions. The inorganic data were collected primarily 
Table 3. Compilation of selected basin characteristics and data used for estimating evapotranspiration in the Price River basin. Site No.: See figure 1 for location.

\begin{tabular}{|c|c|c|c|c|c|c|c|c|c|}
\hline \multirow[b]{2}{*}{$\begin{array}{l}\text { Site } \\
\text { No. }\end{array}$} & \multirow[b]{2}{*}{$\begin{array}{c}\text { Gaging } \\
\text { station } \\
\text { No. }\end{array}$} & \multirow[b]{2}{*}{ Stream } & \multirow[b]{2}{*}{$\begin{array}{c}\text { Drainage } \\
\text { area } \\
\text { (square } \\
\text { miles) }\end{array}$} & \multirow[b]{2}{*}{$\begin{array}{l}\text { Stream } \\
\text { length } \\
\text { (miles) }\end{array}$} & \multirow[b]{2}{*}{$\begin{array}{l}\text { Mean } \\
\text { altitude } \\
\text { (feet) }\end{array}$} & \multirow[b]{2}{*}{$\begin{array}{l}\text { Slope } \\
\text { (feet } \\
\text { per mile) }\end{array}$} & \multicolumn{3}{|c|}{ Precipitation in inches } \\
\hline & & & & & & & $\begin{array}{c}\text { Average }^{1} \\
\text { October- } \\
\text { April } \\
1931-60\end{array}$ & $\begin{array}{c}\text { Intensity }{ }^{2} \\
\text { 24-hour, } \\
\text { 2-year } \\
\text { recurrence }\end{array}$ & $\begin{array}{c}\text { Average } \\
\text { annual } \\
1931-60\end{array}$ \\
\hline S0.5 & 09309800 & Gooseberry Creek & 7.9 & 3.48 & 8,920 & 223 & 22 & 1.8 & 31 \\
\hline S2 & 09310500 & Fish Creek & 60.1 & 14.1 & 8,700 & 85 & 22 & 1.7 & 32 \\
\hline S4 & 09310550 & Pondtown Creek & 11.6 & 9.8 & 8,550 & 142 & 21 & 1.6 & 28 \\
\hline S29 & 09310600 & Eccles Canyon & 5.5 & 3.7 & 9,050 & 322 & 21 & 1.7 & 28 \\
\hline S36 & 09310700 & Mud Creek & 29.1 & 10.8 & 9,000 & 123 & 20 & 1.7 & 28 \\
\hline S37.1 & 09312600 & White River & 75.6 & 20 & 8,050 & 56 & 16 & 1.4 & 22 \\
\hline S37.2 & 09312700 & Beaver Creek & 26.1 & 16.3 & 8,750 & 92 & 15 & 1.4 & 23 \\
\hline S37.3 & 09312800 & Willow Creek & 62.8 & 10.14 & 8,000 & 173 & 11 & 1.4 & 18 \\
\hline S37.4 & 09312900 & do. & 80.6 & 15.80 & 7,950 & 120 & 10 & 1.3 & 18 \\
\hline S37.5 & 09313040 & Spring Canyon & 23.0 & 9.3 & 7,800 & 214 & 12 & 1.3 & 19 \\
\hline S37.6 & - & $\begin{array}{l}\text { North Fork } \\
\text { Gordon Creek }\end{array}$ & 11.2 & 6.9 & 8,500 & 331 & 16 & 1.3 & 22 \\
\hline \$37.7 & 09313965 & Coal Creek & 25.3 & 8.8 & 7,700 & 152 & 9.1 & 1.3 & 16 \\
\hline S59 & 09313975 & Soldier Creek & 17.7 & 6.8 & 7,650 & 157 & 9.0 & 1.3 & 16 \\
\hline S60 & 09313985 & Dugout Creek & 5.7 & 3.26 & 8,020 & 381 & 11 & 1.3 & 18 \\
\hline S61 & 09314340 & Grassy Trail Creek & 40.1 & 13.6 & 8,450 & 205 & 10 & 1.4 & 17 \\
\hline S62 & 09314374 & Horse Canyon & 12.5 & 7.6 & 7,620 & 287 & 8.1 & 1.3 & 15 \\
\hline
\end{tabular}

1 U.S. Weather Bureau (1963)

2 Miller and others (1973)

to aid in understanding the ground water-surface water relationships and the seasonal variation of quality of streams in selected coal-field areas. Samples were collected at seepage-study sites in the Mud and Soldier Creek drainages as well as the gaging stations on Pondtown and Fish Creeks and the Price River downstream from Scofield Reservoir.
Mud Creek Drainage Basin

The low flows of Mud Creek are derived principally from ground water from the Star Point Sandstone and Blackhawk Formations, and high flows are composed of runoff from the same formations. Eccles Canyon is the principal tributary, but Winter Quarters and Boarding- 
house Canyons (fig. 2) also contribute appreciable quantities of inflow. During the 1980 water year, the concentration of dissolved solids at the gaging station in Eccles Canyon (site S29, fig. 2) ranged from 137 milligrams per liter during high flow to 325 milligrams per liter during low flow (fig. 3), and the discharge-weighted average was 220 milligrams per liter.

The principal chemical constituents in the water for all discharges were calcium and bicarbonate. During October 1979 and September 1980, the concentration of dissolved solids at seepage sites in Eccles Canyon ranged from 257 milligrams per liter at the most upstream site (S20) to 280 milligrams per liter at the most downstream site (S30). Calcium and bicarbonate were the principal constituents in the water at all sites. The small range in the concentration of dissolved solids at sites along Eccles Canyon probably was due to the low flow being sustained by inflow from a single aquifer-the Star Point Sandstone.

Large concentrations of nutrients were found in the water at the gaging station in Eccles Canyon (site S29) during the 1980 water year. The largest concentration of both suspended and dissolved nitrogen and phosphorus was on May 22, 1980, during the snowmeltrunoff period. Suspended nitrogen plus dissolved nitrogen were 21 milligrams per liter whereas dissolved nitrogen was only 3.4 milligrams per liter. Suspended phosphorus plus dissolved phosphorus were 4.3 milligrams per liter whereas dissolved phosphorus was only 0.04 milligram per liter. The unusually large concentrations of suspended nutrients during the 1980 water year are believed to be caused by flushing of residual debris associated with the deforestation of planned mining areas.

During the 1980 water year, the concentration of dissolved solids at the gaging station near the mouth of Mud Creek (site S36) ranged from 150 milligrams per liter during high flow to 390 milligrams per liter during low flow (fig. 3), and the discharge-weighted average was 216 milligrams per liter. The principal chemical constituents during all flows were calcium and bicarbonate. The concentration of dissolved solids at the seepage-study sites ranged from 225 milligrams per liter at the most upstream site (S5) to 299 milligrams per liter at the gaging station (S36). The concentrations of nutrients in water in Mud Creek were lower than concentrations in Eccles Canyon, but peak concentrations occurred in May, about the same time as observed in Eccles Canyon. The loads of dissolved nitrogen and phosphorus were computed for the gaging stations in Eccles Canyon and Mud Creek. The computations indicate that about 50 percent of the dissolved load of nitrogen and about 25 percent of the dissolved load of phosphorus discharging from Mud Creek was contributed by Eccles Canyon.
Soldier Creek Drainage Basin

During the 1980 water year, the concentration of dissolved solids at the gaging station on Soldier Creek (site S59, plate 1) ranged from 277 milligrams per liter during high flow to 696 milligrams per liter during low flow. The principal chemical constituents in the water during low flow were sodium, magnesium, sulfate, and bicarbonate; and during high flow they were calcium and bicarbonate.

During 1979-80 water years, the sites concentration of dissolved solids at the seepage-study sites ranged from 520 milligrams per liter (estimated from specific conductance) at the most upstream site (S38) to 692 milligrams per liter at the gaging station (S59). The principal chemical constituents at the upstream site (S38) were sodium, magnesium, and bicarbonate: at the gaging station ( $\mathbf{S} 59$ ), sodium. magnesium. and sulfate.

The concentration of dissolved solids in Pine Creek, the principal tributary of Soldier Creek, ranged from 324 milligrams per liter at the most upstream site (S43) to 353 milligrams per liter at the most downstream site (S52). The principal chemical constituents were magnesium, calcium, and bicarbonate.

\section{Trace Metals}

Analyses for trace metals were made for samples collected in Fish, Pondtown, Eccles, Mud, and Soldier Creeks (table 4). Many of the trace metals shown in table 4 are found in coal wastes; therefore, the analyses were made to determine if mine discharge was affecting the concentration of trace elements in water at the gaged sites. Because of the small number of samples collected from streams and mine discharge, the effects of coal mining cannot be assessed quantitatively. However, the concentrations of trace metals-such as arsenic, lead, and mercury-did not exceed the mandatory maximum contaminant levels set by the U.S. Environmental Protection Agency (1977, p.5).

Waddell and others (1981, p. 33) reported that the concentration of total metals in water from the Utah No. 2 Mine (fig. 2) was several times greater than that of the dissolved metals, and they indicated the danger of accumulation of suspended metals in anaerobic zones. such as in the bottom of Scofield Reservoir. In this study, total metals were not determined in samples from streams, but they were determined for the bottom sediments and water in Scofield Reservoir. (See section on Scofield Reservoir.)

\section{Scofield Reservoir}

Water-quality data were collected at Scofield Reservoir during September and October 1979 and August 1980. In situ measurements of specific conductance, 


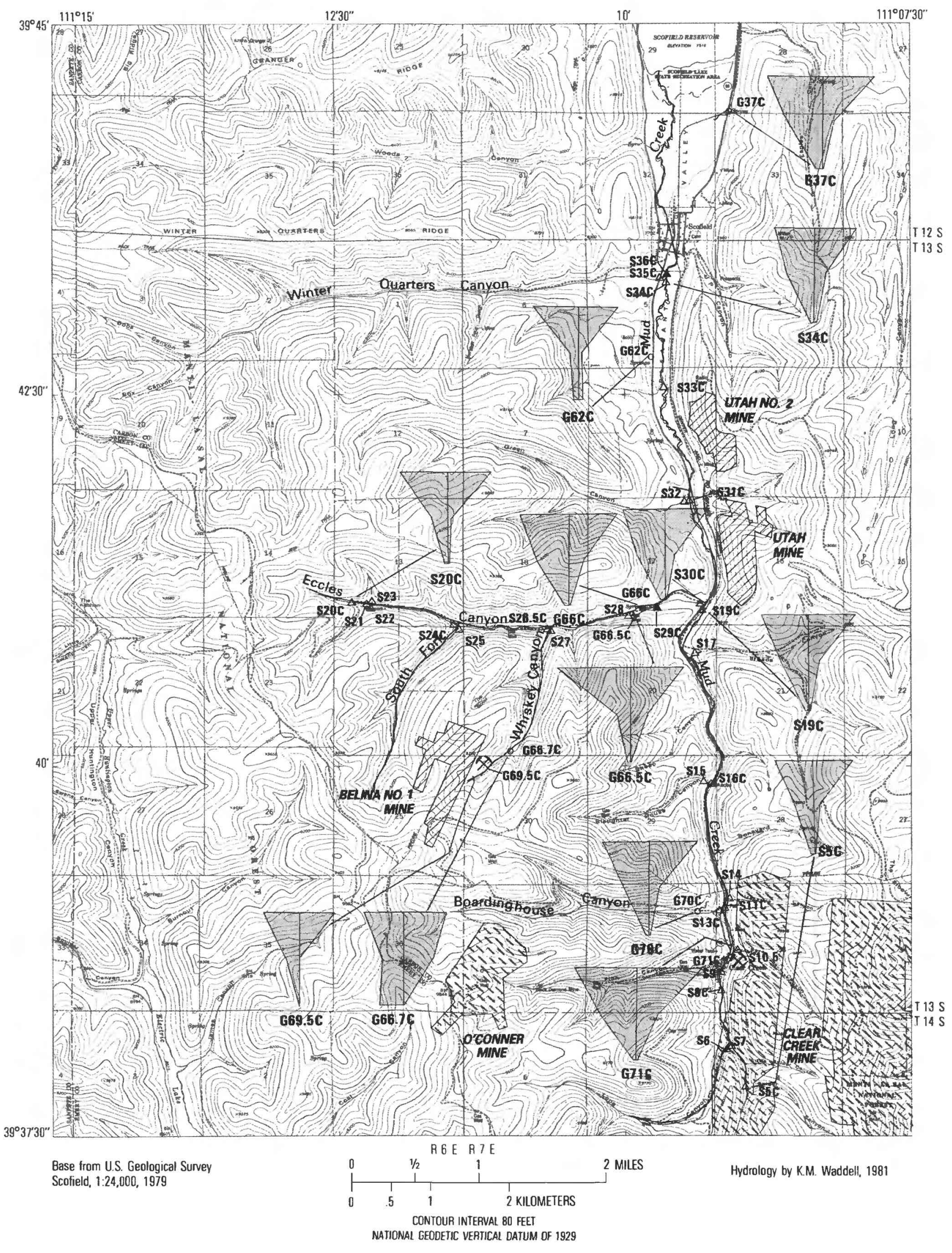




\section{EXPLANATION}

HYDROLOGIC DATA SITE AND NUMBER-G preceding number indicates a ground-water site; $S$ preceding number indicates a surface-water site; $C$ after number indicates chemical analysis available (Waddell and others; 1982 , table 8 or 11 )

$\triangle \quad$ S17 SEEPAGE - STUDY SITE

O G37C SPRING

$\circ$ G66.7 WELL

- g37C gaging station

父 G71C MINE PORTAL

ACTIVE COAL MINE

INACTIVE COAL MINE

WATER-QUALITY DIAGRAM (FROM STIFF, 1951)
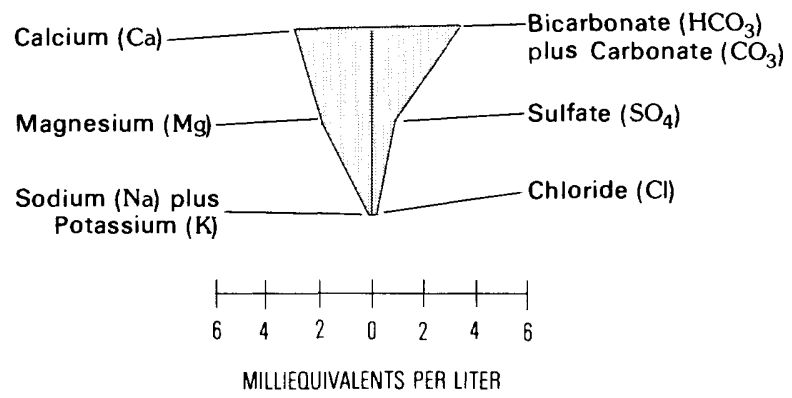

Figure 2. (above and facing page) Seepage-study sites and quality of ground and surface water in the Mud Creek drainage basin, 1979-80.

temperature, $\mathrm{pH}$, and dissolved oxygen were made at 19 sites, and chemical analyses for the major inorganic ions, trace metals, and nutrients were made at 9 of the sites (fig. 4). The purpose of the sampling was to determine: (1) If anaerobic conditions occurred seasonally in the reservoir. (2) sources and quantity of nutrient loading, and ( 3 ) concentration and distribution of trace metals in the reservoir. Only a summary of the results is included in this report.

The three perennial streams that flow into Scofield Reservoir are Fish, Mud, and Pondtown Creeks. The largest stream is Fish Creek, which during the 1971-80 water years had an average annual discharge of about 36.430 acre-feet. During the 1980 water year, Fish Creek had a discharge of 61,690 acre-feet, Mud Creek 13,470 acre-feet, and Pondtown Creek 5,380 acre-feet. The drainage of Mud Creek is in an area with a history of underground mining, and recently mining has accelerated. Little mining has occurred in the drainage of Pondtown Creek.

Storage of water in Scofield Reservoir began in 1926. The usable storage capacity was increased in 1945 when a rockfill dam was constructed about 800 feet downstream from the original dam. In 1945, the usable capacity of the reservoir was 65,780 acre-feet, and dead storage was 8,000 acre-feet. Scofield Reservoir regulates the flow of the Price River. The reservoir provides water for irrigation in the vicinity of the city of Price, and it also provides flood control and recreational facilities.

During September-October 1979, the reservoir water was well mixed. Temperature, specific conductance, concentration of dissolved oxygen, and $\mathrm{pH}$ were homogeneous vertically and areally throughout the reservoir. Temperature ranged from about $13^{\circ}$ to $15^{\circ}$ Celsius, and the concentration of dissolved solids, as estimated from specific conductance, ranged from about 140 to 180 milligrams per liter and averaged about 170 milligrams per liter. The water was well oxygenated, with the concentrations of dissolved oxygen ranging from about 8 to 12 milligrams per liter. The $\mathrm{pH}$ ranged from about 8.6 to 8.9 . The homogeneity of the chemical constituents and physical properties, as well as the turbidity and suspension of algae, indicated that the water in the reservoir was mixing because of autumn turnover.

During August 1980, the reservoir was stratified. A well mixed layer of water with almost constant temperature existed above an altitude of about 7.585 feet above sea level. The average depth below the lake surface of thickness of this zone was about 25 feet. Such a zone in a reservoir is defined as the epilimnion (Hutchinson, 1957, p. 427). A poorly mixed zone, or metalimnion, occurred in the reservoir at depths below the altitude of about 7,585 feet. The average thickness of the metalimnion was about 10 feet, and it was confined to the deeper parts of the reservoir. At the lower part of the metalimnion, below the altitude of about 7,577 feet, was a zone of water that was depleted of dissolved oxygen (anaerobic). The thickness of the anaerobic zone was about 2 feet.

Stratification in the reservoir also was evident for specific conductance and $\mathrm{pH}$. Above an altitude of about 7,585 feet, the concentration of dissolved solids (as estimated from specific conductance) ranged from about 165 to 170 milligrams per liter; below an altitude of 7,585 feet, the concentration ranged from about 170 to 180 milligrams per liter. The $\mathrm{pH}$ ranged from about 8.5 to 8.9 above an altitude of 7,585 feet and from about 7.6 to 8.5 below 7,585 feet.

Dissolved and suspended nutrients were determined for 23 samples collected from the reservoir during 1979 and 1980. Dissolved and suspended nitrogen were separated into the inorganic and organic phases. Inorganic nitrogen includes nitrate, nitrite, and ammonia converted to an equivalent concentration of nitrogen as $\mathrm{N}$. 

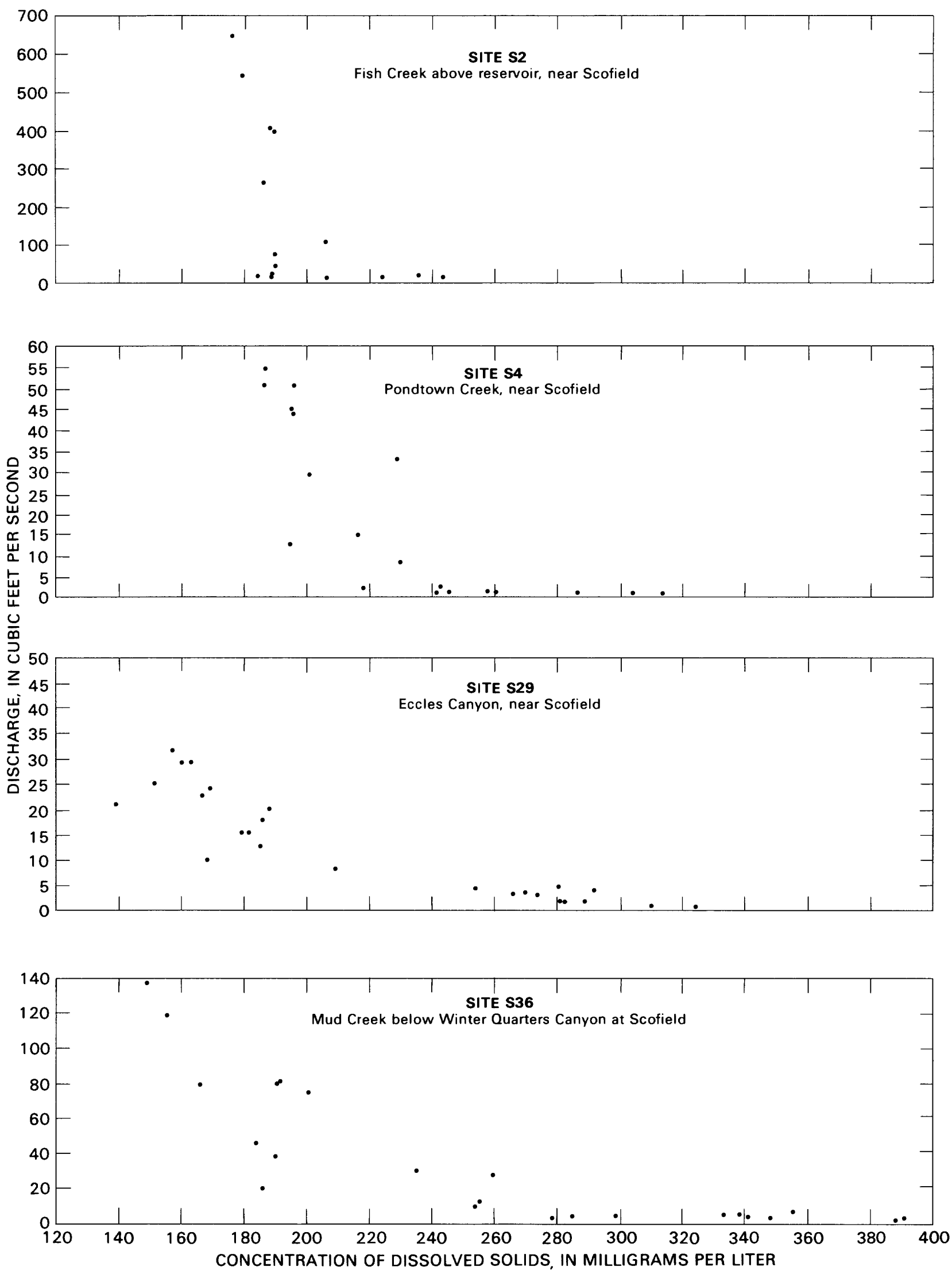

Figure 3. Relationship between the concentration of dissolved solids and discharge for selected streams in the Price River basin, 1980 water year. 
Table 4. Range of concentration of dissolved trace elements for selected streams, October 1, 1979-August 31, 1980 Site No.: See figure 1 for location. All concentrations in micrograms per liter.

\begin{tabular}{|c|c|c|c|c|c|c|c|c|c|c|}
\hline $\begin{array}{l}\text { Site } \\
\text { No. }\end{array}$ & Stream & & Arsenic & Boron & Copper & Iron & Lead & Mercury & Selenium & Zinc \\
\hline \multirow[t]{3}{*}{ S2 } & Fish Creek & Maximum & $<1$ & 30 & $<10$ & 160 & 13 & $<0.1$ & $<1$ & 10 \\
\hline & & Minimum & $<1$ & $<5$ & $<1$ & 10 & $<1$ & $<.1$ & $<1$ & $<3$ \\
\hline & & $\begin{array}{l}\text { Number of } \\
\text { measurements }\end{array}$ & 6 & 6 & 6 & 5 & 6 & 5 & 7 & 7 \\
\hline \multirow[t]{3}{*}{ S4 } & Pondtown Creek & Maximum & $<1$ & 40 & $<10$ & 450 & 21 & $<.1$ & $<1$ & 440 \\
\hline & & Minimum & $<1$ & 6 & $<1$ & 10 & $<1$ & $<.1$ & $<1$ & $<3$ \\
\hline & & $\begin{array}{l}\text { Number of } \\
\text { measurements }\end{array}$ & 8 & 8 & 7 & 7 & 7 & 6 & 8 & 8 \\
\hline \multirow[t]{3}{*}{ s29 } & Eccles Canyon & Maximum & $<1$ & 40 & 9 & 50 & 5 & $<.1$ & $<1$ & 180 \\
\hline & & Minimum & $<1$ & $<5$ & $<1$ & 10 & $<1$ & $<.1$ & $<1$ & $<3$ \\
\hline & & $\begin{array}{l}\text { Number of } \\
\text { measurements }\end{array}$ & 9 & 9 & 5 & 9 & 8 & 6 & 9 & 9 \\
\hline \multirow[t]{3}{*}{ S36 } & Mud Creek & Maximum & 2 & 60 & $<10$ & 30 & 28 & $<.1$ & $<1$ & 10 \\
\hline & & Minimum & $<1$ & 10 & $<1$ & 10 & $<1$ & $<.1$ & $<1$ & $<3$ \\
\hline & & $\begin{array}{l}\text { Number of } \\
\text { measurements }\end{array}$ & 9 & 9 & 6 & 8 & 9 & 4 & 9 & 9 \\
\hline \multirow[t]{3}{*}{ S37 } & Price River & Maximum & 1 & 30 & $<10$ & 20 & 19 & $<.1$ & $<1$ & 20 \\
\hline & & Minimum & $<1$ & 4 & $<1$ & $<10$ & $<1$ & $<.1$ & $<1$ & $<3$ \\
\hline & & $\begin{array}{l}\text { Number of } \\
\text { measurements }\end{array}$ & 6 & 6 & 6 & 5 & 6 & 4 & 6 & 6 \\
\hline \multirow[t]{8}{*}{ S59 } & Soldier Creek & Maximum & 3 & 280 & 2 & 20 & 3 & $<.1$ & 3 & 20 \\
\hline & & Minimum & $<1$ & 40 & $<1$ & $<10$ & $<1$ & $<.1$ & $<1$ & $<3$ \\
\hline & & $\begin{array}{l}\text { Number of } \\
\text { measurements }\end{array}$ & 7 & 7 & 2 & 7 & 7 & 2 & 7 & 7 \\
\hline & \multicolumn{10}{|c|}{ Recommended maximum limits } \\
\hline & \multicolumn{10}{|c|}{ Domestic water supply ${ }^{1}$} \\
\hline & & & 50 & - & - & - & 50 & 2.0 & 10 & - \\
\hline & \multicolumn{10}{|c|}{ Freshwater aquatic life 2} \\
\hline & & & 50 & - & $(3)$ & 1,000 & (3) & .05 & $(3)$ & $(3)$ \\
\hline
\end{tabular}

1 U.S. Environmental Protection Agency, 1976, p. 5.

2 U.S. Environmental Protection Agency, 1978, p. 14-245.

3 Limit is dependent on type of aquatic species as well as other chemical constituents and physical properties of the water.

Most of the dissolved nitrogen was in the organic form. The maximum concentration of dissolved inorganic nitrogen during 1979 was 0.12 milligram per liter, and during 1980 the maximum was 0.47 milligram per liter as shown in the table below:

\begin{tabular}{|c|c|c|c|c|c|c|c|c|}
\hline & \multicolumn{4}{|c|}{$\begin{array}{l}\text { Dissolved nitrogen as } \mathrm{N} \\
\text { (milligrams per liter) }\end{array}$} & \multicolumn{4}{|c|}{$\begin{array}{l}\text { Suspended nitrogen as } \mathrm{N} \\
\text { (milligrams per liter) }\end{array}$} \\
\hline & \multicolumn{2}{|c|}{$\begin{array}{c}\text { Inorganic } \\
\text { (nitrate }+ \text { nitrite }+ \text { ammonia }) \\
\end{array}$} & \multicolumn{2}{|c|}{ Organic } & \multicolumn{2}{|c|}{$\begin{array}{c}\text { Inorganic } \\
\text { (nitrate }+ \text { nitrite }+ \text { ammonia) } \\
\end{array}$} & \multicolumn{2}{|c|}{ Organic } \\
\hline & Minimum & Maximum & Minimum & Maximum & Minimum & Maximum & Minimum & Maximum \\
\hline 1979 & 0.01 & 0.12 & 0.42 & 0.81 & 0.12 & 1.44 & $<0.01$ & 1.37 \\
\hline 1980 & .05 & .47 & .38 & .63 & $<.01$ & .01 & $<.01$ & 3.62 \\
\hline
\end{tabular}




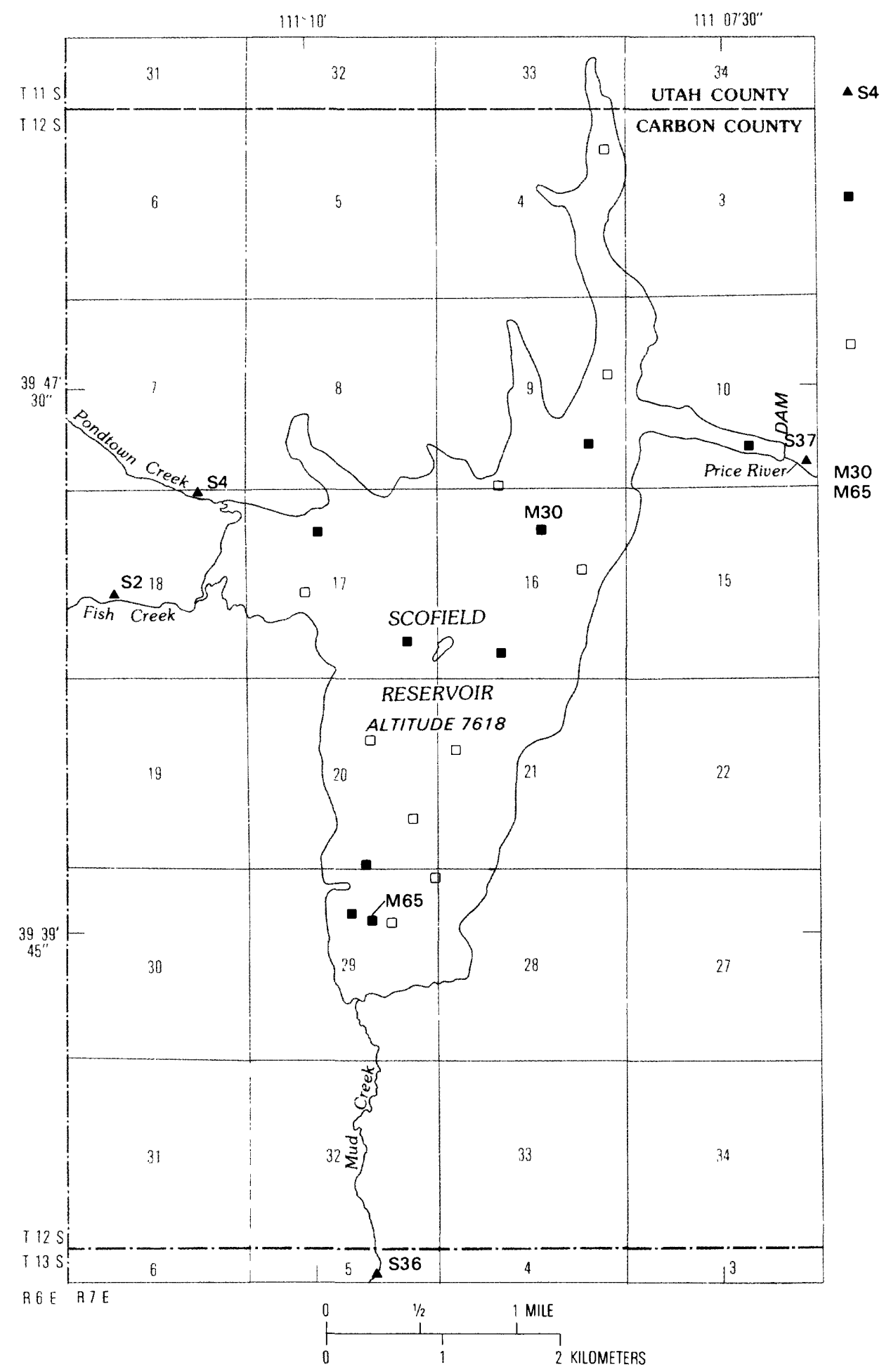

EXPLANATION

GAGING STATION AND CHEMICAL-QUALITY SAMPLING SITE ON STREAM-Data available in Waddell and others (1982, Tables 9 and $11-13$ )

CHEMICAL-OUALITY SAMPLING SITE AND ONSITE MEASUREMENT OF TEMPERATURE, $\mathrm{PH}$. SPECIFIC CONDUCTANCE, AND DISSOLVED OXYGEN - Data available in Waddell and others (1982, Tables 18-20)

ONSITE MEASUREMENT OF TEMPERATURE, $\mathrm{pH}$, SPECIFIC CONDUCTANCE, AND DISSOLVED OXYGEN - Data available in Waddell and others (1982, Table 20)

SITES WHERE CORE SAM PLES OF LAKE-BOTTOM SEDIMENTS WERE COLLECTED

Figure 4. Location of water-quality and core-sampling sites in the Scofield Reservoir area.

Most of the dissolved inorganic nitrogen was in the form of ammonia, and it was in the lower part of the metalimnetic layer where anaerobic conditions existed. The concentration of dissolved organic nitrogen ranged from 0.38 to 0.81 milligram per liter during 1979 and 1980 , and the maximum concentration was at the 1-foot depth at site M5 near the dam in 1979.

Suspended inorganic nitrogen ranged from 0.12 to 1.44 milligrams per liter during 1979 but was equal to or less than 0.01 milligram per liter during 1980. Most 
of the suspended inorganic nitrogen was in the form of ammonia, and the largest concentration was at a depth of 1 foot at site M20, which is about three-fourths of a mile upstream from the dam. Suspended organic nitrogen varied from less than 0.01 to 3.62 milligrams per liter, and the largest concentration was at a depth of 1 foot at site M65, which is near the inflow of Mud Creek. The concentration of total phosphorus, which includes dissolved and suspended phosphorus, ranged from 0.01 to 0.11 milligram per liter.

The concentration of dissolved arsenic, chromium, lead, and selenium did not exceed the recommended maximum contaminant levels set by the U.S. Environmental Protection Agency (1977, p. 5). Reducing conditions in the anaerobic zone resulted in increased concentrations of iron and manganese. During August 1980, in the anaerobic zone at site M5, the concentration of iron was 60 micrograms per liter and that of manganese was 750 micrograms per liter. At most sites and depths during 1979 and 1980, however, the concentration of dissolved iron was less than about 30 micrograms per liter and that of dissolved manganese was less than about 100 micrograms per liter.

\section{Sediment in Streams and Scofield Reservoir}

Although most of the planned coal mining in the study area is to be underground, that does not preclude the possibilities of accelerated erosion or changes in the sediment characteristics of streams. The coal spoils associated with past mining have affected the sediment characteristics of previously mined areas such as Spring Canyon Creek near Helper. Mundorff (1972, p. 37) described the effects of past mining: "The characteristics of the sediment transported by Spring Canyon Creek at Helper*** were unique among the streams observed in the Price River basin. During some periods, the transported sediment is principally coal particles that range up to an inch in diameter***. On August 29, 1969 , a sample obtained at a water discharge of $0.6 \mathrm{cfs}$ had a suspended-sediment concentration of $2,260 \mathrm{mg} / \mathrm{L}$; approximately 90 percent of the sediment was coal. Thus, the creek was contributing coal at the rate of about 3 tons per day to the Price River. On November 6,1969 , the water discharge was $1 \mathrm{cfs}$, the suspendedsediment concentration was $502 \mathrm{mg} / \mathrm{L}$ and about 95 percent of the sediment was coal. Appreciable amounts of coal were not observed in Grassy Trail Creek, Willow Creek, or other streams in areas of coal mining."

Forested areas surrounding the portals of underground mines were cleared to aid in the prevention of forest fires. For example, in Eccles Canyon (tributary of Mud Creek ), 27.3 acres of forested land were cleared during 1980. This included land cleared for roads as well as land cleared to aid in the prevention of forest fires (Allan Owen, Coastal States Energy Co., oral commun., May 7, 1980).

Waddell and others (1981, p1. 6) show the estimated sediment yields for the Wasatch Plateau and Book Cliffs area, which includes the Price River basin. The sediment yields were based largely on the geology of the study area.

During the $1978-80$ water years, sediment characteristics were studied using the following techniques: (1) Determination of particle size of bed material in selected sections of streams upstream and downstream from active and potential coal-mining areas by photogrammetry, using a Zeiss ${ }^{1}$ analyzer and photographs of the streambed. (2) determination of the mineralogy of the streambed sediments, (3) determination of the volume of sediment deposition in Scofield Reservoir through comparison of bathymetric profiles, (4) determination of sedimentaccumulation rates using lead-210 and cesium-137 radiochemical-dating techniques, and (5) sampling of thunderstorm runoff.

Except for the drainage upstream from Scofield Reservoir, no attempts were made during this study to determine sediment yields. A large percentage of sediment yields generally occur during infrequent but intense thunderstorms, and the sediment data collected were not adequate to determine sediment yields. Sediment concentration and discharge during snowmelt runoff usually is greater than during low flows in streams, but the concentrations are usually much less than the concentrations during thunderstorm runoff for a given discharge (Mundorff, 1972, p. 36).

\section{Bed Material}

Particle Size

During 1979, particle-size data were collected at 13 sites (fig. 1). The size data were used to help explain the distribution of benthic invertebrates. Lium (1974) determined that the density of insects increased with rock diameters from 22 to 64 millimeters, and then decreased as rock diameters increased to 256 millimeters.

Photographs of bed material were taken from the right, middle, and left sides of the stream at sites where benthic invertebrates were collected. Where the streams were too narrow, photographs were taken at selected sites diagonally across the stream. The photographic technique was used because of the difficulty of collecting representative samples for particle-size analysis in the mountainous areas where a typical section may range from bedrock at one point to clays, sands, and pebbles at another point in the same section (Guy, 1969, p. 48).

'The use of brand names in this report is for identification only and does not constitute endorsement by the U.S. Geological Survey. 
The distribution of particles for selected sites on streams is shown in figure 5 , together with photographs of sections 1-square foot in area. Although three photographs were taken at each site, several were not suitable for interpretation. Thus, at most sites the particle-size distribution for only one or two sections were determined.

The procedure does not provide accurate data unless the streams are clear and water depths are less than approximately 0.2 foot. A 35 -millimeter SLR camera with a polarizing filter was used, but only about one-half of the photographs were suitable for interpretation. The quality of the photographs probably could have been enhanced in some streams by temporary diversion of water around the section being photographed.

All the streams that were sampled had particles that exceeded 19 millimeters in diameter. Because 19 millimeters was the largest particle size that was contained in all samples, it was used as a base by which to test the relationship between diversity index and particle size. The percentage of total cross-sectional area with average particle sizes of bed material greater than 19 millimeters was compiled for each of the stream sites and were plotted in figure 10 to show the relationship to the benthic-invertebrate diversities. (See section on benthic invertebrates.) At all sites in the Soldier Creek drainage of the Book Cliffs (except site S42), the percentage of particles greater than 19 millimeters was less than for streams in the Wasatch Plateau. This probably is due primarily to the greater velocities of streams in the Wasatch Plateau.

Mineralogy

Waddell and others (1981, p. 32) suggested a qualitative procedure for documenting the mineralogy of existing sediments in coal-mining areas so that changes related to mining could be detected with future studies. Following that procedure, bed-material samples were collected during water year 1979 at 13 stream sites in the study area. Mineralogic analyses were performed by M.J. Sweeney, Salt Lake City, Utah, using methods suggested by Schultz (1964). The results of the analyses are presented in Waddell and others (1982). The samples were split and then analyzed in sizes less than 0.476 millimeter and less than 0.062 millimeter. The size less than 0.476 millimeter was comparable to the particle size that was analyzed for samples collected in 1976 by Waddell and others (1978, table 14).

The Flagstaff Limestone and Colton Formation of Eocene and Paleocene age underlie most of the drainage of the headwaters of Soldier Creek, and the principal rock types exposed are limestone, dolomite, and sandstone. The North Horn Formation of Paleocene and Cretaceous age, and the Price River Formation. Castlegate
Sandstone, and Blackhawk Formation of Cretaceous age underlie the downstream part of the drainage, and the principal rock types exposed are sandstone and shale. Waddell and others $(1981$, p. 32$)$ indicated that in the Soldier Creek drainage there was a general downstream trend of decreasing calcite content and increasing claymineral content in bed material. Those trends reflect the geologic transition downstream as the rock types change from predominantly limestone and dolomite to sandstone and shale.

Four sites that were sampled in 1976 were resampled in 1979 to determine if there were consistency in the mineralogic character of bed material at a given site. (See figure 6.) For particle sizes less than 0.476 millimeter, the percentage composition of the major minerals at the upstream and downstream sites (S42 and S59) on Soldier Creek are similar. The percentage composition of minerals at the intermediate sites, site S57 on Soldier Creek and site S51 at the mouth of Pine Canyon, however, were considerably different, with calcite and dolomite and quartz showing the largest changes. It should be noted. however, that site $\mathrm{S} 57$ is downstream from Pine Canyon; and during 1976 and 1979, the mineralogic composition was similar at sites S57 and S51. Apparently the composition at site $\mathrm{S} 57$ is affected by the same factors that affect the bed material of Pine Canyon. The large percentages of calcite and dolomite that were observed near the mouth of Pine Canyon at site S51 and at Soldier Creek at site S57 during 1976 may be due to chemical changes that are occurring in the water along the reach of Solider Creek downstream from Pine Canyon. In 1979, it was noted that the rocks and smaller particulates along this reach were cemented to the streambed by carbonate precipitates.

The Blackhawk Formation and the Star Point Sandstone of Cretaceous age underlie most of the drainage of Mud Creek. The Blackhawk is predominant in the headwaters, and the Star Point is predominant in the downstream reaches of Mud Creek and its principal tributary, Eccles Canyon.

Five samples were collected in the Mud Creek drainage during 1979, three on Mud Creek and two in Eccles Canyon. No previous data were available to use for comparative purposes. The most obvious trend in the mineralogy of bed material on Mud Creek was the downstream decrease in the percentage of quartz (fig. 6), particularly for particle sizes less than 0.062 millimeter. However, the percentage composition of the other minerals does not have consistent trends along the reach.

\section{Deposition in Scofield Reservoir}

A bathymetric survey was conducted and cores of bottom sediments were collected from Scofield Reservoir 
during 1979-80. The purpose of the survey was to provide: (1) A basis for estimating the total sediment yield from inflowing streams since an earlier survey made in 1943 by the U.S. Bureau of Reclamation, and (2) more detailed bathymetric measurements at selected cross sections so that future deposition can be evaluated more accurately.

The total accumulation of sediments that were deposited in Scofield Reservoir during 1943-79 was computed by comparing the 1943 and 1979 bathymetric surveys. The wet volume of sediments that accumulated during 1943-79 was computed to be 3.000 acre-feet. Using the ratio of 60 pounds of dry sediment per cubic foot of wet sediment, as determined from laboratory analysis of core samples, the dry weight of sediment was determined to be 3.9 million tons. For the approximately 113 square miles of drainage area upstream from the reservoir (using a specific weight of 80 pounds per cubic foot of dry sediment), this is equivalent to an average sediment yield of about 960 tons per square mile per year, or about 0.5 acre-foot per square mile per year.

An estimate of the rate of sediment accumulation and deposition also was made by determining the age of sediments for two cores (sites M30 and M65 in fig. 4) collected in the reservoir. The age of the sediments was determined by use of the radioisotope lead-210, which has a half-life of about 21.4 years. It is a decay product of gaseous radon-222. Much of the lead-210 is removed from the atmosphere by rain and eventually becomes attached to soils, some of which are eroded and deposited in lakes. The older, deeper sediments have less lead- 210 activity than the surface sediments. After plotting the activity of lead-210 for different depths of sediment, the age of the sediments was determined from the curve showing the relation between lead-210 activity and depth of sediment (fig. 7). For example, it requires 21.4 years for one-half the lead-210 to decay. So by choosing two points on the curve such that the lead- 210 activity of one point is one-half the activity of the other point, the corresponding depth of sediment that was deposited during 21.4 years can be determined on the vertical scale. The rate of sediment deposition is then calculated by dividing the depth of sediment deposition by 21.4 years.

The rate of accumulation for the two (wet) cores ranged from 0.18 to 0.60 centimeter per year and averaged about 0.31 centimeter per year (fig. 7 ). The standard error of the mean of the six measurements was 0.02 centimeter per year; and for a 90-percent probability level, the confidence interval of the sample mean is $0.31 \pm 0.04$ centimeter per year. There is, therefore, a 90-percent probability that the average for the two samples is somewhere between 0.27 and 0.35 centimeter per year. By converting the average rate of accumulation of wet sediment to an average rate of dry sediment and estimating the reservoir area in which the sediment was deposited, the average sediment yield from the drainage basin was estimated as 0.2 acre-foot per square mile per year. This is $2 \frac{1}{2}$ times less than the rate of 0.5 acre-foot per square mile per year computed from the bathymetric surveys, but it is in the same range as the yield of 0.10 to 0.20 acre-foot per square mile per year that is indicated on the U.S. Department of Agriculture (1973) map for the drainage area upstream from Scofield Reservoir.

The bathymetric survey and radiochemical-dating techniques both have errors associated with the computed sediment yields. The 1943 bathymetric map had 5-foot contour intervals. whereas the 1979 map had 1-foot contour intervals. Future bathymetric surveys should yield accurate sedimentation rates provided that the cross sections ( \pm 0.5 -foot depth) used in 1979 are duplicated with equivalent accuracy. Also, cores from only two sites were used for radiochemical dating during 1980 , and the samples were sliced in 7.5- to 10-centimeter sections. Radiochemical dating would provide more satisfactory results if samples were collected at a larger number of sites and if the core were divided into smaller increments, perhaps 1 to 5 centimeters. Samples need to be collected near the inflow of Fish Creek, at site M5 near the dam, as well as at sites M30 and M65. Also, the homogeneity of the samples needs to be determined.

The distribution of metals and coal was determined in the cores from sites M30 and M65 (fig. 4). The vertical distribution of coal in the sediment and the approximate time of deposition are shown in figure 8 . The core from site M65, which is near the inflow of Mud Creek, had considerable coal distributed throughout; but most of the deposition was prior to about 1950 . The core from site M30, which is near the outflow of the reservoir, had much smaller coal content; but as at site M65, most of the coal deposition occurred prior to about 1950. The core from site M30 has much less coal probably because the site is far from major inflow points, and sediments deposited at this site are a composite from the three major inflowing streams.

The distribution of arsenic. mercury, cobalt, copper. iron, lead, manganese, nickel, and zinc were determined for the silicate, nonsilicate, and nondetrital sediment phases using procedures described by Skei and Paus (1978, p. 240-241). Several of these metals are potentially toxic pollutants, and the effect of metal-enriched sediments on benthic organisms and fish has been noted by several investigators, including Bryan and Hummerstone (1973) and Ayling (1974).

The analyses indicate that the greatest concentrations of most metals in each of the three phases generally occurred near the top surface of the sediments. This was especially true of iron, manganese, lead, and zinc but not so pronounced in the other metals, including arsenic and mercury. The accumulation of metals in the surface 


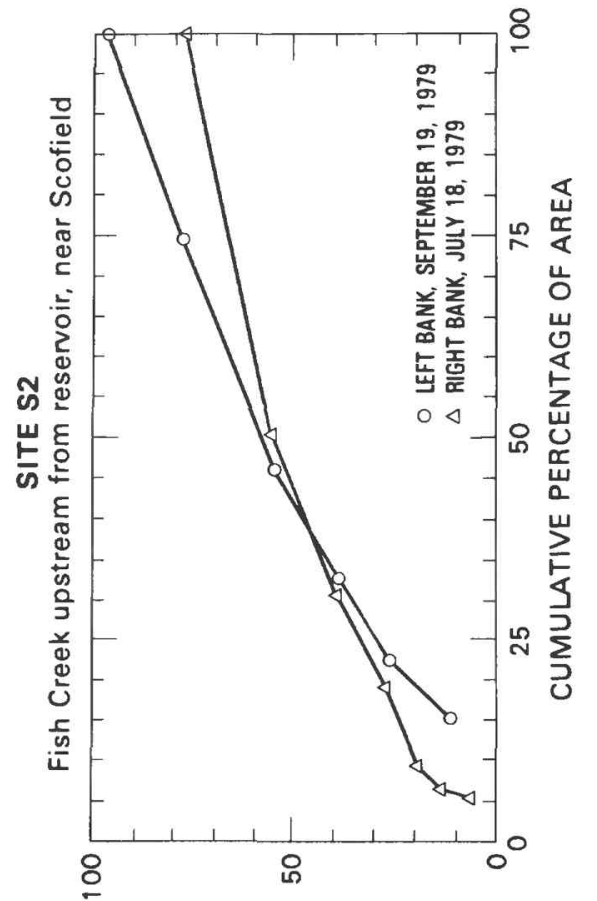

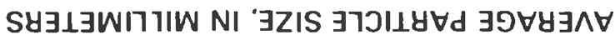
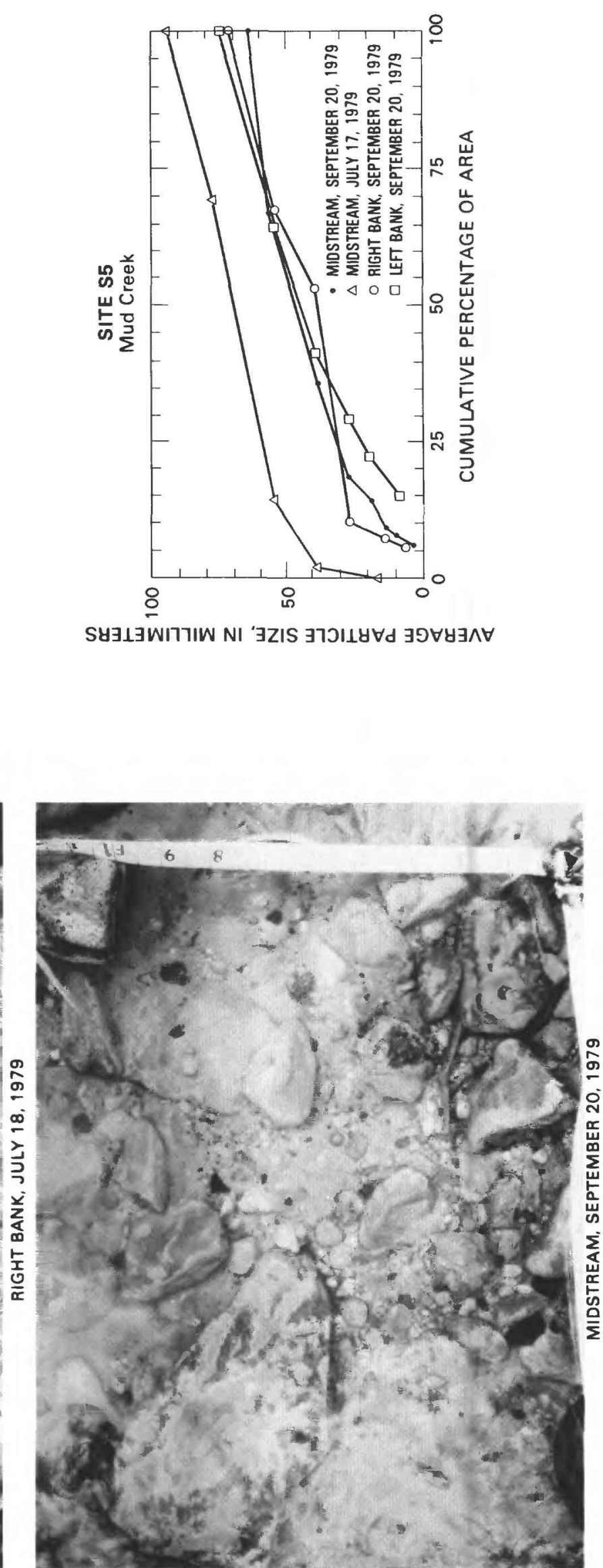


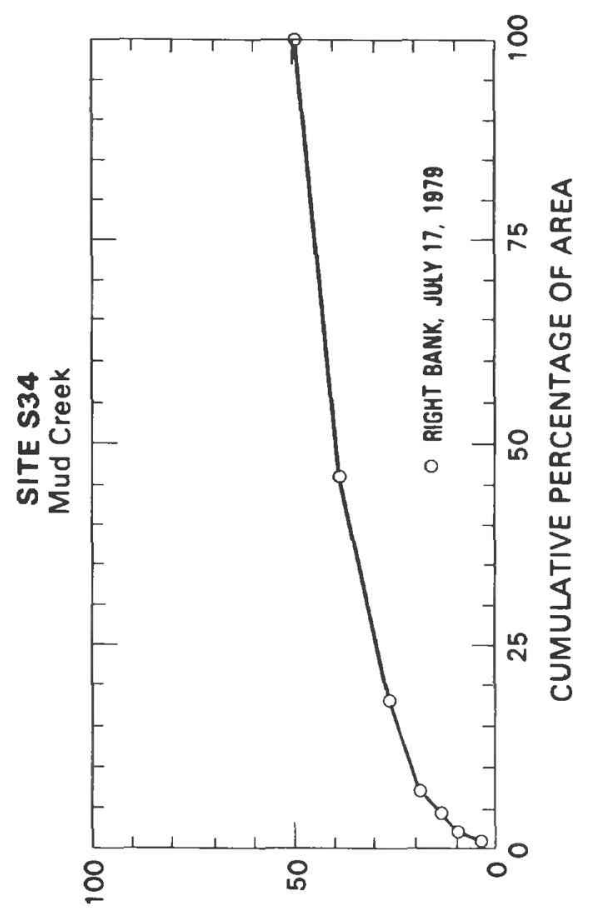

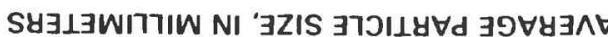

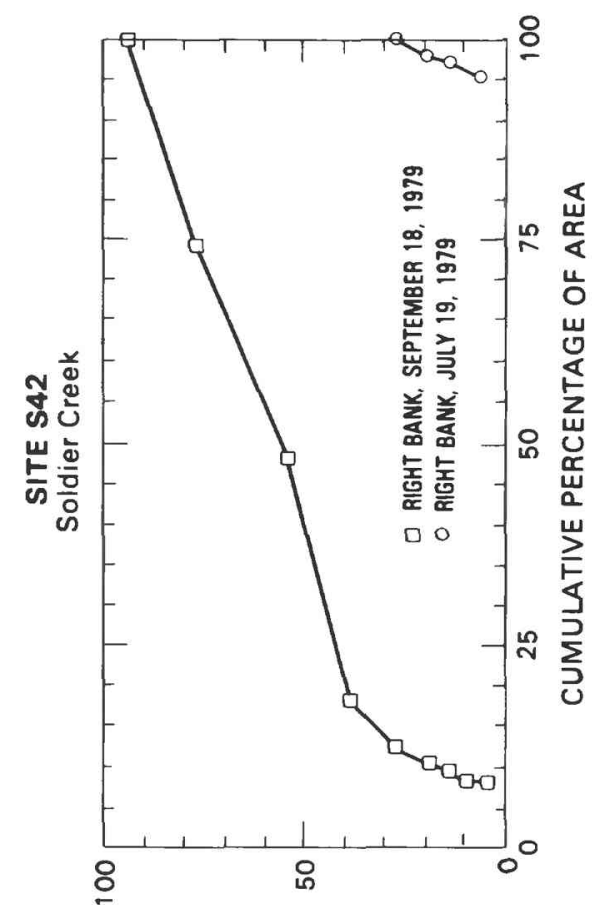

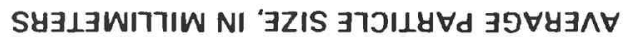
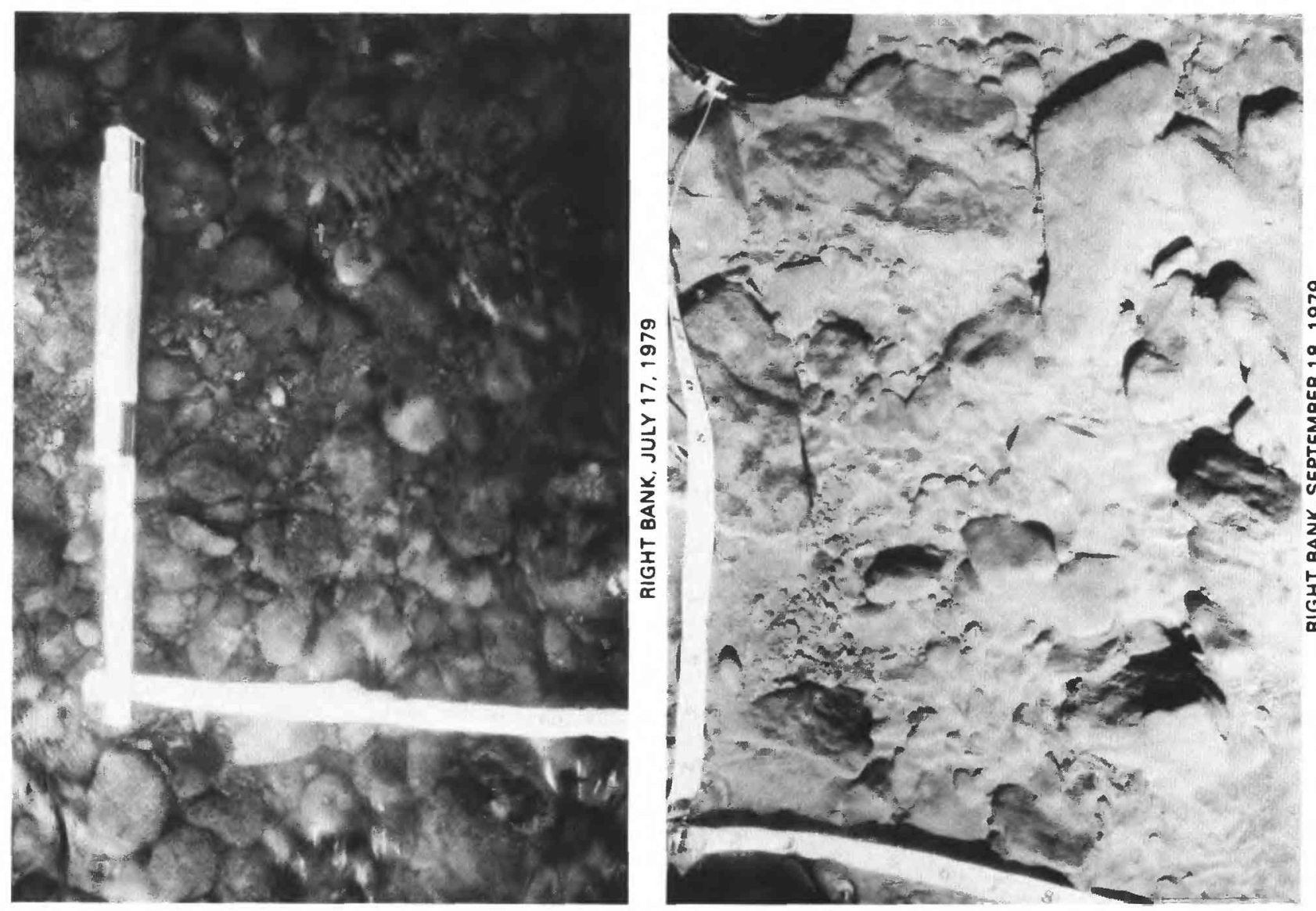

Surface Water

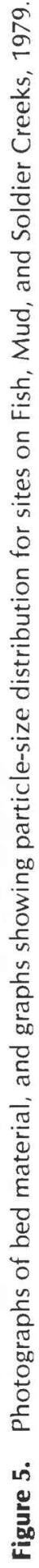




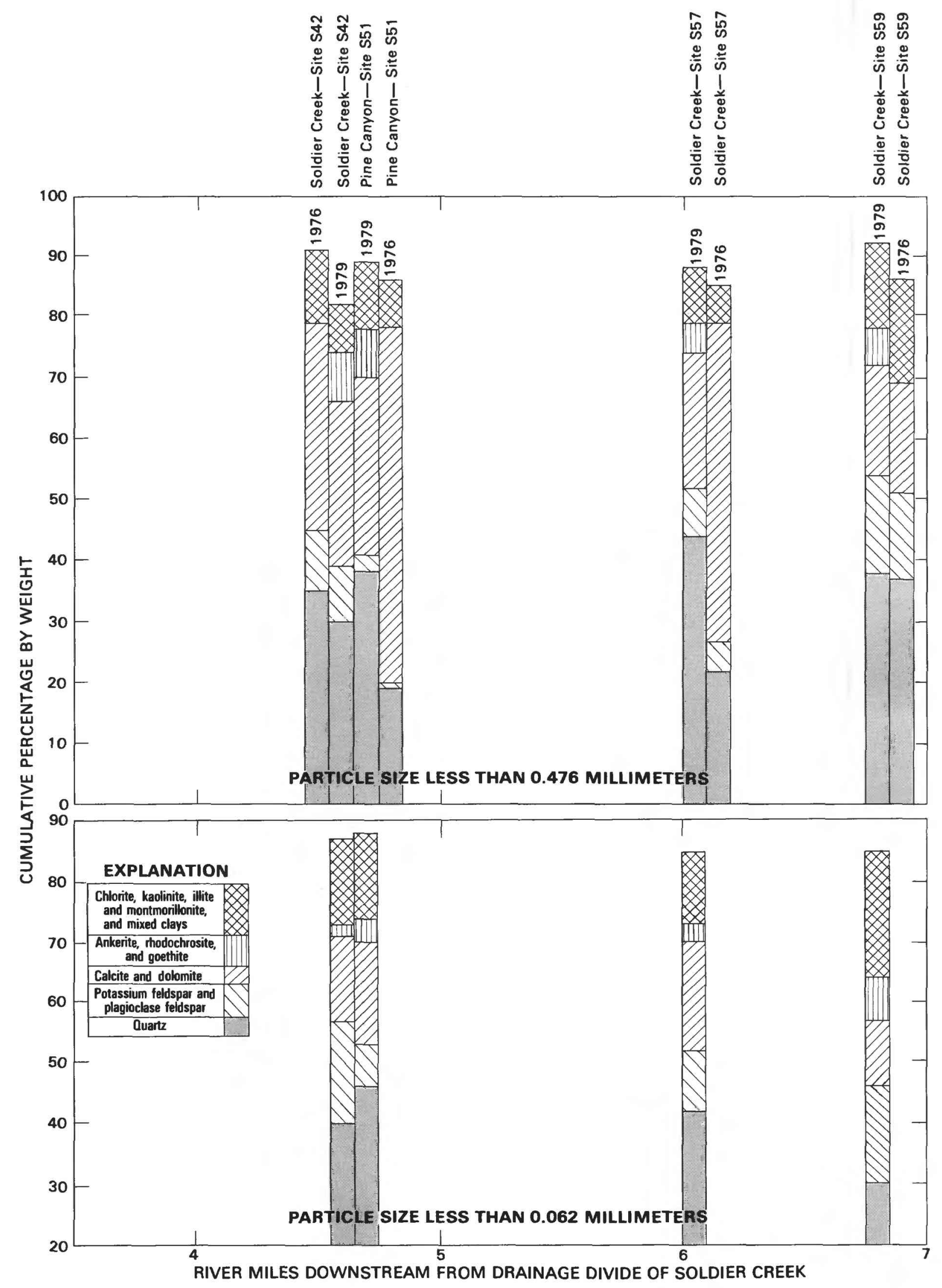




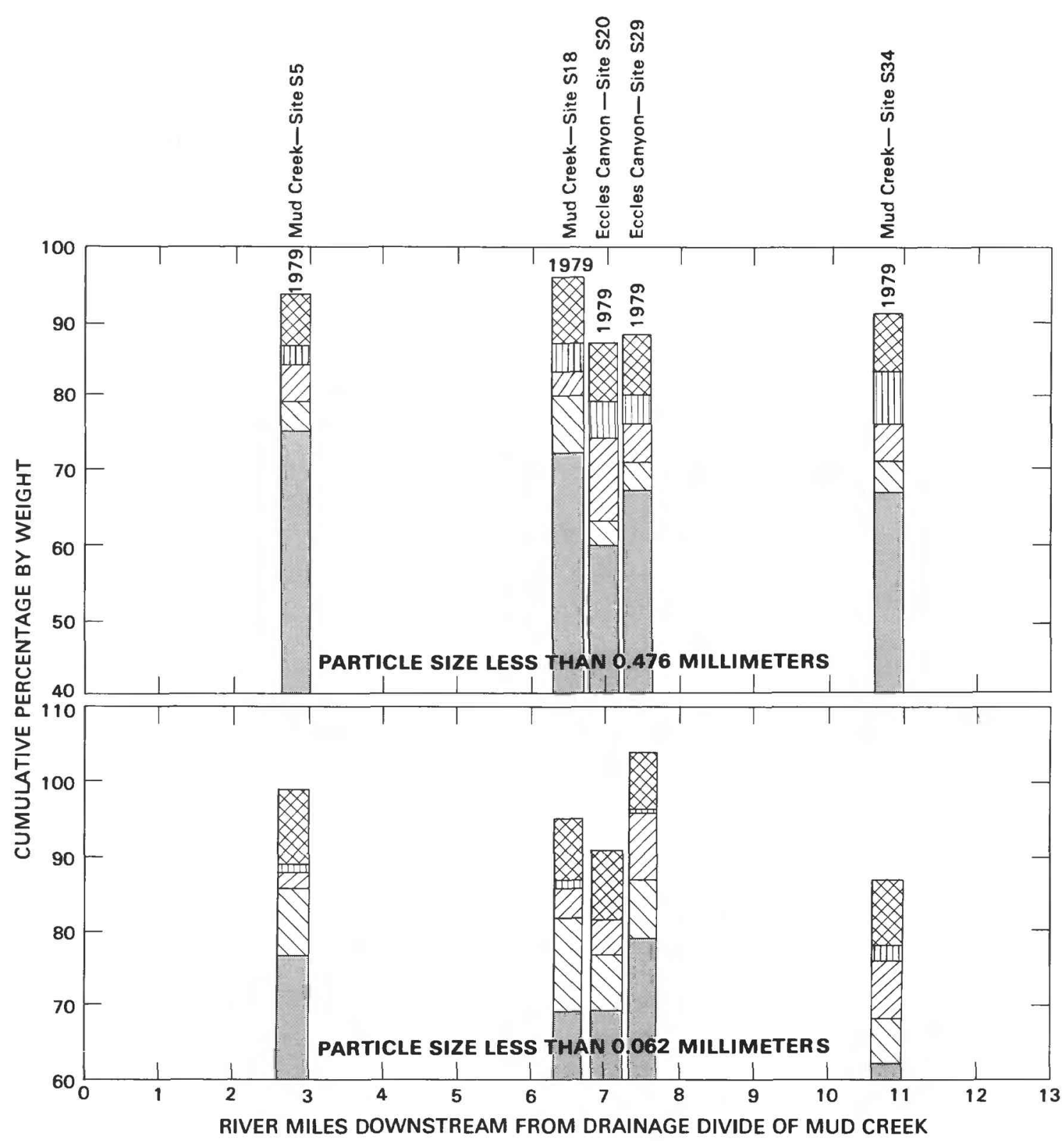

Figure 6. (above and facing page) Mineralogic composition of bed material at sites in the Soldier Creek area and Mud Creek drainage basin, 1976 and 1979.

layer probably is due to the occurrence of reducing conditions at depth within the sediments and the more oxidizing environment near the sediment-water interface. Several of the metals, such as iron and manganese, are more soluble in a reducing environment. After the metals are dissolved, they may redeposit near the watersediment interface, where oxidizing conditions are more likely to occur.

\section{Thunderstorm runoff}

The runoff from a thunderstorm on July 19, 1979 as sampled at the gaging station at the mouth of Solider
Creek in the Book Cliffs (site S59). Concentrations of suspended sediment and the two discharge peaks resulting from the storm are shown in figure 9. The first peak is due to runoff from Pine Canyon, a major tributary of Soldier Creek, and the second peak is due to the runoff from upper Soldier Creek. The greatest concentration of sediment was during the second peak, even though the first peak had a greater discharge. The peak discharge during this storm was about 17 cubic feet per second, and the maximum measured concentration of suspended sediment was 37,000 milligrams per liter. In contrast, a sample collected during snowmelt runoff on May 14, 1980, at a discharge of about 50 cubic feet per 


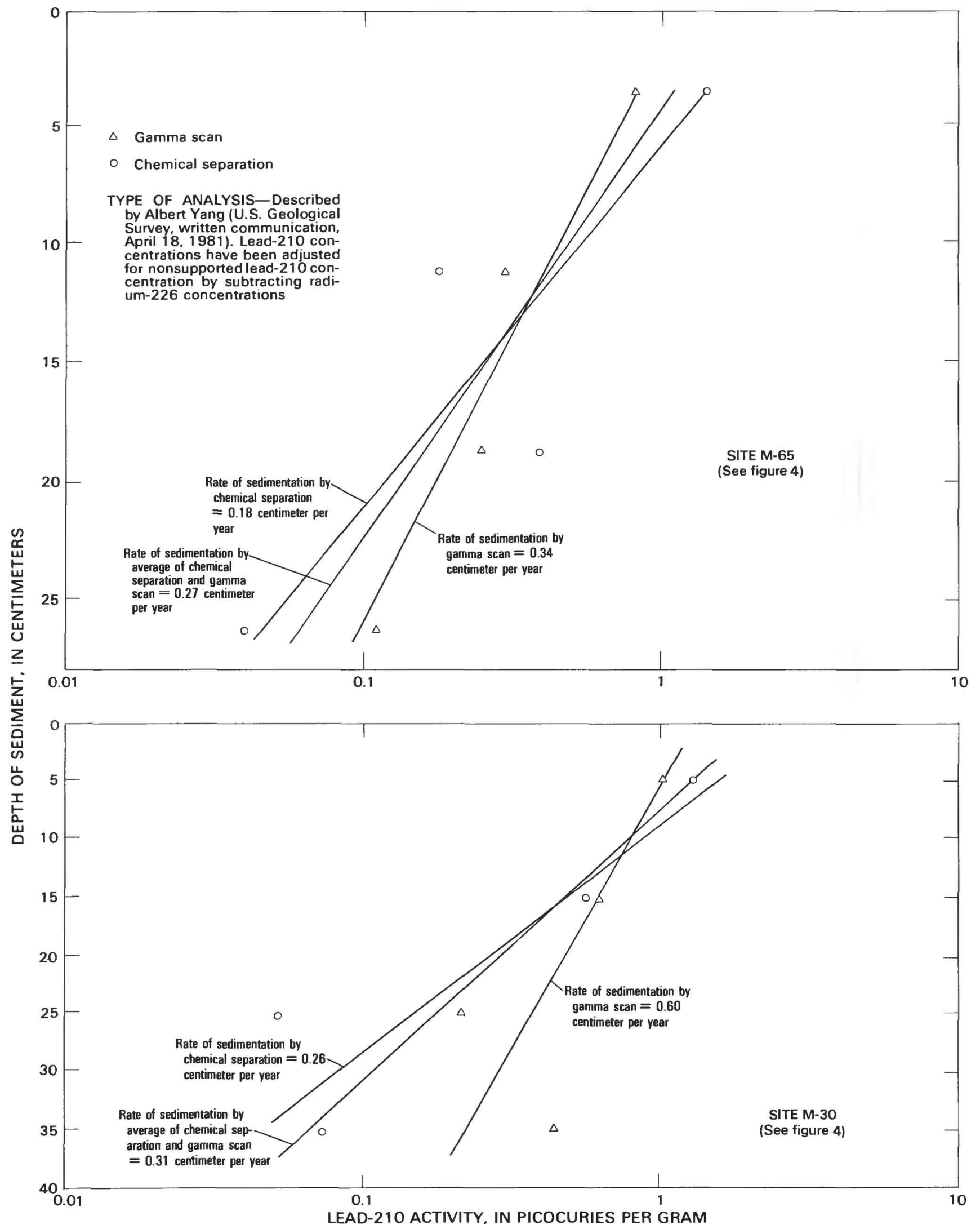

Figure 7. Relationship of relative lead-210 activity and depth of sediment in Scofield Reservoir, 1980. 


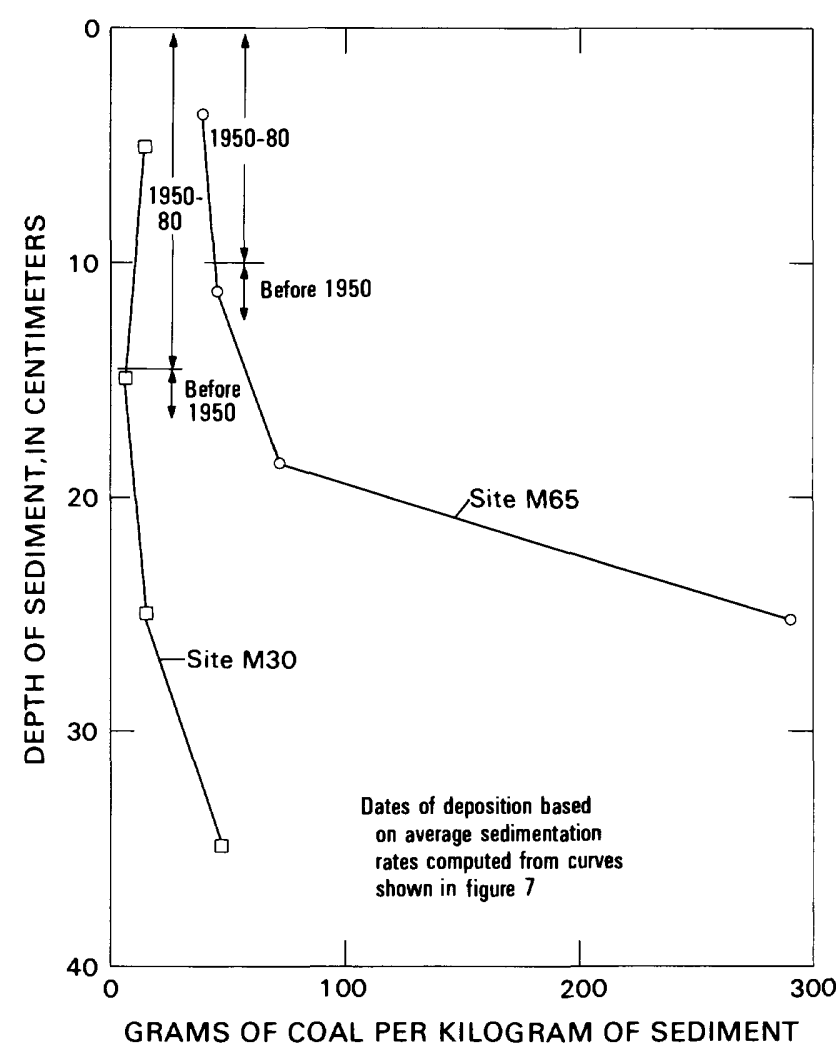

Figure 8. Vertical distribution of coal in sediment cores from Scofield Reservoir, 1980.

second had a suspended-sediment concentration of 650 milligrams per liter.

Thunderstorms created by moisture moving north from the Gulf of Mexico occur frequently in the Book Cliffs during late summer. On September 10, 1980, a peak flow of 90 cubic feet per second was recorded for a storm at the gage on Soldier Creek (site S59). Although a sample was not obtained, the concentrations of suspended sediment from such a storm probably would exceed that of the smaller storm sampled during July 1979. Because of the areal and temporal differences that may occur in thunderstorm activity over the Book Cliffs area, no attempt was made to compute sediment-yield rates from the data available only for the storm of July 1979.

\section{Benthic Invertebrates}

Nine sites on five streams in the Wasatch Plateau were sampled for benthic invertebrates during 1979-80. Benthic invertebrates, which live on the streambed material, include worms, mollusks, crustaceans, and juvenile forms (larvae, pupae, and nymphs) of aquatic insects. Four sites on Gooseberry, Fish, and Pondtown Creeks were sampled to serve as a control on natural seasonal variations in benthic-invertebrate population, so that changes related to mining in the Mud Creek drainage could be evaluated. A listing of collected species of benthic invertebrates is given by Waddell and others (1982, table 14), and diversity indexes are discussed in the following pages.

The diversity indexes ${ }^{1}$ for benthic invertebrates collected during the 1979 water year are shown in figure 10 , together with data for the percentage of streambed with particle size greater than 19 millimeters. In the Soldier Creek drainage (Book Cliffs), where the area with particle sizes greater than 19 millimeters ranged from 0 to 40 percent, benthic diversities were much smaller than at most sites in the Wasatch Plateau where the corresponding range was from about 40 to 100 percent. The results could change, however, if sediment analyses were available for all three sampling sections in each stream. For most of the sites, only one or two sediment analyses are available.

In the Mud Creek drainage area, three sites were sampled on Mud Creek and two sites in Eccles Canyon. Each site was sampled in July and September 1979, and July and October 1980. The samples showed a large seasonal fluctuation of Ephemeroptera (mayflies), Plecoptera (stoneflies), and Trichoptera (caddisflies), which are indicators of nonpolluted water. Also, there were a variety of Haplotaxida (annelid worms), Acari (water mites), Heterodonta (clams, mussels), and Copepoda (crustaceans). The diversity indexes at the five sites ranged from 1.57 to 4.20 during the four sampling periods. (fig. 11). There is a consistent downstream, as well as seasonal trend in the diversity index for the sites on Mud Creek, as well as Eccles Canyon. At the upstream sites on Mud Creek, which are upstream from Eccles Canyon, the diversity index decreased between sites S5 and S18 during sampling periods in July 1979 and July 1980. Then during the September 1979 and October 1980 sampling periods, the diversity indexes increased from site S5 to site S18. At the most downstream site on Mud Creek (S34), which is downstream from Eccles Canyon, the diversity index was greater than at site S18 during all four sampling periods.

The diversity index also decreased during all four sampling periods at both sites in Eccles Canyon. The decrease may be related to construction associated with

'Diversity, or the evenness of distribution of aquatic organisms, gives some indication of the environmental condition of the stream (the quality of water and the types of material in the streambed). Diversity was computed for each sample by phylogenetic order using the Shannon-Weiner approximation:

$$
\text { Diversity index }=-\Sigma P_{i} \log _{2} P_{i} \text {, }
$$

where $P_{i}$ is the probability of occurrence of the ${ }_{i}$ th order. The probability $\left(P_{i}\right)$ is equal to $N_{i} / N_{s}$, where $N_{i}$ is the number of individuals in each order and $N_{S}$ is the total number of individuals in all orders (Lium. 1974, p. 382). 


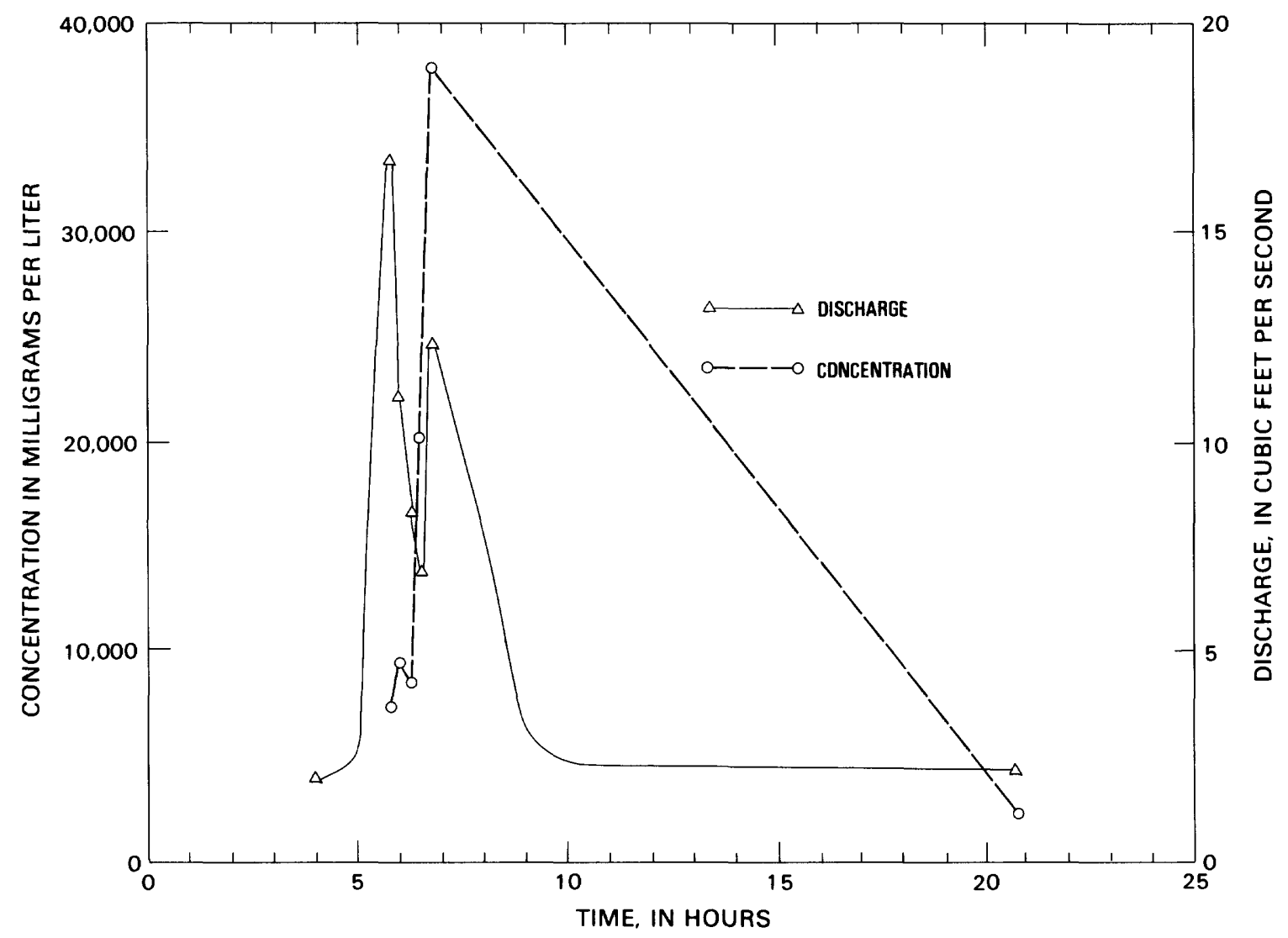

Figure 9. Relationship of concentration of suspended sediment and water discharge during thunderstorm runoff at gaging station on Soldier Creek (site S59), July 19, 1979.

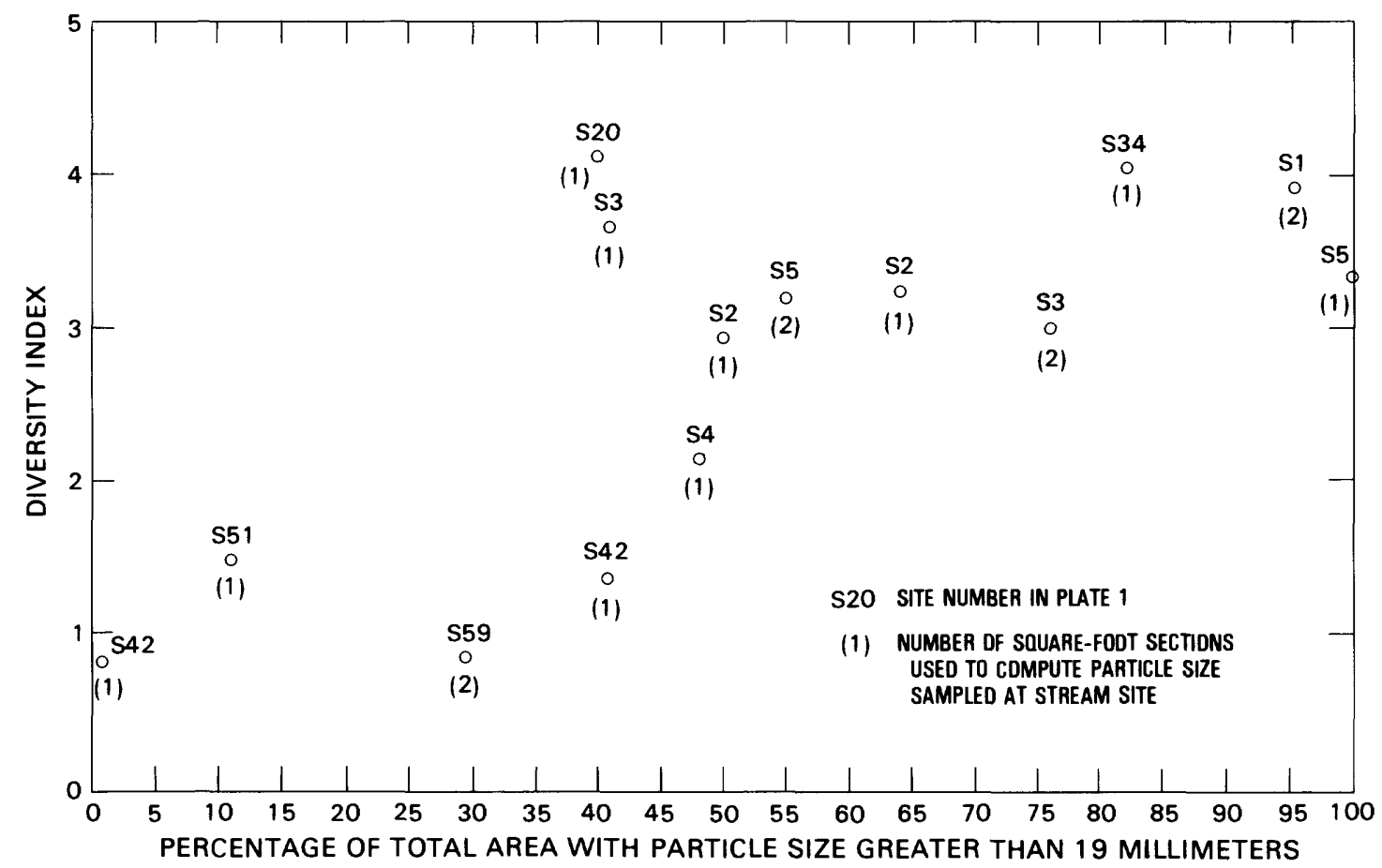

Figure 10. Relationship of benthic-invertebrate diversity and particle size for selected sites, 1979. 


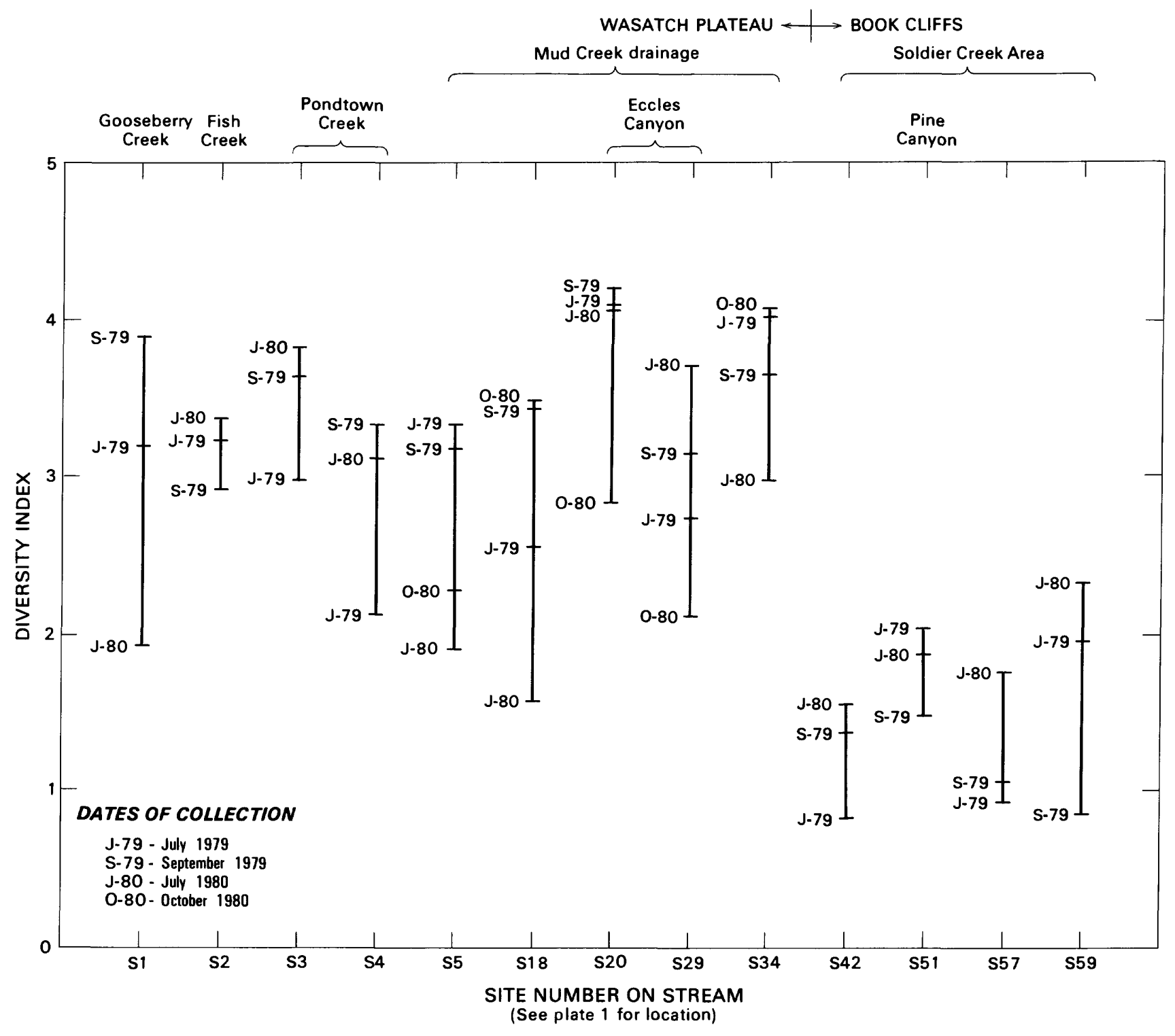

Figure 11. Range of benthic-invertebrate diversity index at selected sites, 1979-80.

clearing of the canyon and disturbance of the stream channel downstream from site S20. Hundreds of feet of stream channel were replaced by culverts in the upper part of Eccles Canyon. The culverts were placed either in or alongside the original channel and then covered with fill. This construction activity may have caused sufficient change in the sediment characteristics of the stream to temporarily affect the benthic-diversity index. The downstream decrease in diversity in Eccles Canyon observed in 1979 and 1980 is not believed to be associated with seasonal trends, because during 1979 at most of the sites on Mud Creek and in adjacent drainages, including Gooseberry and Pondtown Creeks, the diversity indexes increased between July and September.
The diversity index of benthic invertebrates at four sites on Gooseberry, Fish, and Pondtown Creeks during 1979 ranged from 2.1 to 3.9 (fig. 11). The reason for the increased diversity index at most of these streams between July and September probably is due to the warming of stream temperatures through the summer, which is conducive to egg hatching and the seasonal reproductive cycles of most benthic invertebrates. In the Soldier Creek drainage, four sites were sampled in July and September 1979 and July 1980. The samples generally showed one dominant species of Ephemeroptera (mayflies), Plecoptera (stoneflies), and Trichoptera (caddisflies), and a few Haplotaxida (annelid worms), Acari (water mites), Heterodonta (clams, mussels), and 
Copepoda (crustaceans). The diversity indexes at the four sites ranged from 0.8 to 2.3 during the three sampling periods. The generally small diversity indexes are believed to be related to the small particle size of the sediments and to the carbonate precipitates, which cement the bed material.

During July 1979, the diversity index increased from 0.82 at the most upstream site (S42) to 1.96 at the most downstream site (S59). Then during September 1979, the downstream trend was reversed as the diversity index decreased from 1.36 at the upstream site (S42) to 0.85 at the downstream site (S59). During July 1980, the diversity index decreased downstream similar to the trend during July 1979.

The precipitation of carbonates may cause the downstream trend to reverse between summer and fall. During the spring runoff each year, a new benthic environment in Soldier Creek is created by movement of sediments. Then during the following low-flow period in the late summer and fall, the sediments are cemented together again by precipitation of carbonates, thus decreasing the available habitat and consequently the benthic diversity.

Pine Canyon, which is a major tributary of Soldier Creek, had a similar seasonal trend in diversity index at site S51. The largest diversity indexes of 2.04 and 1.87 were determined during the July sampling periods of 1979 and 1980, and the smallest diversity index was determined during September 1979.

\section{GROUND WATER}

\section{Discharge From Springs}

Springs and seeps in the study area primarily are associated with faulting or contacts between zones or beds of differing permeability. Springs contribute considerable quantities of inflow directly to streams from point sources, and also there is usually a large quantity of seepage to stream reaches where springs issue along the valley wall above the stream channel.

In the Wasatch Plateau, where faulting is extensive, many large springs discharge from fractured rocks bounding faults. Most of the springs discharge from the Mesaverde Group and the Flagstaff Limestone.

In the Book Cliffs, many springs issue near the contact of the Flagstaff Limestone and the underlying North Horn Formation. Water moving down through the Flagstaff is forced out to the surface by the clay, mudstone, and shale layers that impede downward percolation into the North Horn. The Flagstaff produces most of the ground-water runoff from a perched system, which has only a small volume of storage. This is demonstrated by springs at which the discharge is greater than 100 gallons per minute immediately following snowmelt but decreases to less than 15 gallons per minute by fall.

The discharge of springs varies in response to natural recharge as well as to man's activities that affect the ground-water system. Thus, it is necessary to define the natural cycles of discharge of springs prior to the introduction of man's activities in order to distinguish between natural or man-caused fluctuations. During June-September 1980, beginning near the end of the snowmelt period, about two or three measurements of discharge and specific conductance were made each month at 33 springs, a flowing well, and outflow from an abandoned mine (table 5). Most of the springs were concentrated in the Beaver and Mud Creek drainages and the Soldier Creek area, and they were selected to represent a range of altitudes as well as geologic variations. The locations of the springs are shown in plate 1 .

The slope of the recession curve of the discharge of each spring provides a relative index of seasonal variability of discharge. The slope of the recession was computed in a manner similar to that for streams (see section on ground water-surface water relationships), on the basis of the number of days required for the discharge of the spring to decrease through one log cycle. The steeper the recession curve, the smaller the number of days per log cycle and the greater the seasonal variability of the spring discharge. The recession of some springs had two separate, but distinctly different, slopes. When two slopes occurred, the initial slope following snowmelt was labeled S1 and the subsequent slope S2 (table 5).

Two primary variables that control the discharge of springs are the transmissivity and storage properties of the source aquifer. A convenient term for combining the effects of transmissivity and storage properties of an aquifer is the hydraulic diffusivity: $D=T / S$, where $T$ is the transmissivity, $S$ is the storage coefficient, and $D$ is the hydraulic diffusivity of the aquifer.

Hydraulic diffusivity is used in this report to discuss the relative hydraulic characteristics of aquifers in the Beaver Creek and Mud Creek drainages and the Soldier Creek area. Even though neither $T$ nor $S$ is known in most of the study area, the response of the discharge of springs to snowmelt provides an estimate of the hydraulic diffusivity. Generally, the greater the seasonal variability, as indicated by the smaller values of $S 1$ or S2, the greater the value for hydraulic diffusivity.

\section{Beaver Creek Drainage Basin}

The discharges of six springs and a flowing well (first 7 entries in table 5) varied from less than 0.01 to 181 gallons per minute. The slopes of recession curves for the springs at higher altitudes are steep, which is indicative of a large seasonal variability (fig. 12). Spring G45, 
Table 5. Selected characteristics of springs, a well, and a mine that were monitored during 1980

Site No.: See plate 1 for location. All sites are springs except G71 which is a mine and G73 which is a flowing well.

Geologic unit: ALVM, Alluvium: CLTN, Colton Formation: FLGF, Flagstaff Limestone: NRHR. North Horn Formation, PCRV, Price River Formation: CSLG. Castlegate Sandstone: BCKK. Blackhawk Formation; SRPN, Star Point Sandstone.

Slope of Recession: When two distinct slopes occurred in the recession curves the initial slope is S1 and the subsequent slope is S2.

Range of discharge and specific conductance: Represents range that occurred during June-September 1980.

Number of measurements: Represents number of discharge and specific conductance measurements.

\begin{tabular}{|c|c|c|c|c|c|c|}
\hline \multirow[t]{2}{*}{$\begin{array}{l}\text { Site } \\
\text { No. }\end{array}$} & \multirow[t]{2}{*}{$\begin{array}{l}\text { Altitude } \\
\text { (feet above } \\
\text { sea level) }\end{array}$} & \multirow[t]{2}{*}{$\begin{array}{c}\text { Geologic } \\
\text { unit }\end{array}$} & $\begin{array}{l}\text { Slope of recession } \\
\text { (days per log cycle) }\end{array}$ & $\begin{array}{l}\text { Range of discharge } \\
\text { (gallons per minute) }\end{array}$ & $\begin{array}{c}\text { Range of specific } \\
\text { conductance } \\
\text { (micromhos per cent- } \\
\text { meter at } 25^{\circ} \mathrm{C} \text { ) } \\
\end{array}$ & \multirow[t]{2}{*}{$\begin{array}{l}\text { Number of } \\
\text { measurements }\end{array}$} \\
\hline & & & S2 & Minimum Maximum & Minimum Maximum & \\
\hline
\end{tabular}

\begin{tabular}{|c|c|c|c|c|c|c|c|c|c|}
\hline G45 & 8,660 & CSLG & 14 & - & $<0.01$ & 21 & 406 & 522 & 5 \\
\hline G44 & 8,590 & PCRV & 60 & 210 & 1.9 & 21 & 483 & 528 & 8 \\
\hline G65 & 8,550 & BCKK & 89 & 130 & 16 & 130 & 461 & 478 & 8 \\
\hline G76 & 8,315 & CSLG & 55 & 316 & 1.0 & 18 & 397 & 497 & 8 \\
\hline G46 & 8,240 & PCRV & 108 & $>365$ & 10 & 34 & 393 & 472 & 8 \\
\hline G48 & 8,230 & PCRV & 172 & - & 59 & 181 & 471 & 534 & 8 \\
\hline G73 & 8,160 & CSLG & $>365$ & - & 50 & 65 & 481 & 498 & 8 \\
\hline
\end{tabular}

Mud Creek drainage basin

\begin{tabular}{|c|c|c|c|c|c|c|c|c|c|}
\hline G71 & 8,320 & BCKK & $>365$ & - & 197 & 282 & 656 & 707 & (1) \\
\hline G66 & 8,060 & SRPN & $>365$ & - & 90 & 107 & 563 & 590 & 14 \\
\hline G64 & 7,840 & BCKK & $>365$ & - & 1.6 & 1.8 & 443 & 479 & 10 \\
\hline G62 & 7,760 & ALVM & $>365$ & -- & 2.6 & 3.0 & 399 & 449 & 9 \\
\hline G41 & 7,690 & ALVM & $>365$ & - & 15 & 26 & 523 & 546 & 8 \\
\hline G37 & 7,675 & ALVM & $>365$ & - & 189 & 296 & 625 & 695 & 10 \\
\hline \multicolumn{10}{|c|}{ Soldier Creek area } \\
\hline G96 & 8,360 & CLTN & 24 & $>365$ & 6.3 & 103 & 550 & 657 & 9 \\
\hline G91 & 8,120 & FLGF & 42 & 105 & 3.3 & 125 & 497 & 587 & 8 \\
\hline G92 & 8,090 & FLGF & 78 & 209 & 7.1 & 89 & 468 & 546 & 9 \\
\hline G95 2 & 7,990 & FLGF & 44 & 205 & 15 & 242 & - & - & 8 \\
\hline G95 & 7,990 & FLGF & 79 & 295 & 15 & 97 & 566 & 619 & 8 \\
\hline G97 & 7,940 & FLGF & 43 & 352 & 1.6 & 89 & 499 & 625 & 8 \\
\hline G90 & 7,900 & FLGF & 53 & - & 0 & 112 & 673 & 689 & 6 \\
\hline $\mathrm{G} 94^{3}$ & 7,870 & FLGF & 70 & 265 & 13 & 332 & - & - & 8 \\
\hline G94 & 7,870 & FLGF & 115 & 251 & 13 & 76 & 577 & 612 & 8 \\
\hline G93 & 7,740 & FLGF & 73 & 263 & 13 & 249 & 502 & 549 & 8 \\
\hline G88 & 7,520 & FLGF & 37 & - & 0 & 3.9 & 513 & 612 & 5 \\
\hline G89 & 6980 & NRHR & $>365$ & - & 4.1 & 6.3 & 1,060 & 1,100 & 10 \\
\hline G100 & 6,950 & BCKK & 116 & $>365$ & 5.5 & 13 & 1,000 & 1,050 & 12 \\
\hline
\end{tabular}

1 Continuous record.

2 Represents combined flow from site 95 and stream seepage upstream from site 95.

3 Represents combined flow from site 94 and stream seepage upstream from site 94 .

which discharges from the Castlegate Sandstone, is at the highest altitude of the springs monitored in the Beaver Creek drainage basin. It had a recession index of only 14 days, and the discharge varied from less than 0.01 to 21 gallons per minute (fig. 12). Spring G76 issues from the Castlegate Sandstone at a lower altitude than spring G45. and it has a smaller variability of flow. Well G73, which is an uncontrolled, flowing well about 160 feet deep, is the lowest of the discharge points monitored in the Castlegate Sandstone. The well had a reces- 
sion index greater than 365 days, and the discharge ranged from 50 to 65 gallons per minute. The decrease in variability of discharge with decreasing altitude indicates that the aquifer has a greater hydraulic diffusivity at higher altitudes. This indicates that the hydraulic diffusivity of the Castlegate Sandstone aquifer decreases with decrease in altitude, probably due to an increase in the storage coefficient rather than a decrease in the transmissivity. The variability of discharge from springs G44, G46, and G48, which issue from the Price River Formation, also is indicative of increasing storage coefficient with decrease of altitude.

\section{Mud Creek Drainage Basin}

The discharges of five springs and an abandoned mine were monitored during 1980 in the Mud Creek drainage basin. All the springs that were monitored issue along or near the floor of Pleasant Valley and are associated with the Pleasant Valley fault. The discharges of the springs and the mine ranged from 1.6 to 296 gallons per minute (table 5). The slope indexes, S1 and S2, of the recession curves were greater than 365 days per log cycle, thus indicative of small seasonal variability. Peak discharges of two of the larger springs and of the mine occurred between June and August (fig. 12).

Spring G66, locally known as Iron Spring, discharges at an altitude of 8,060 feet from the Star Point Sandstone near the intersection of Eccles Canyon and the Pleasant Valley fault. The water level in well G66.5, which is completed in the Star Point Sandstone and is less than 500 feet from the spring, was 8,039 feet above sea level during October 1980. The similarity of altitudes indicates that the spring is issuing from a point near the top of the saturated zone in the Star Point Sandstone. The large discharges and small seasonal variability of springs issuing along the Pleasant Valley fault indicate that the Star Point Sandstone has a large storage capacity and a relatively large transmissivity.

\section{Soldier Creek Area}

The discharges of 11 springs in the Soldier Creek area were monitored during 1980. Eight of the springs issue from the Flagstaff Limestone and the other three issue from the Colton, North Horn, and Blackhawk Formations, respectively. The discharges of the springs issuing from the Colton Formation and Flagstaff Limestone ranged from 0 to 332 gallons per minute, and the discharges of the springs issuing from the North Horn and Blackhawk Formations ranged from 4.1 to 13 gallons per minute.

The discharges of most springs issuing from the Colton Formation and Flagstaff Limestone have a large
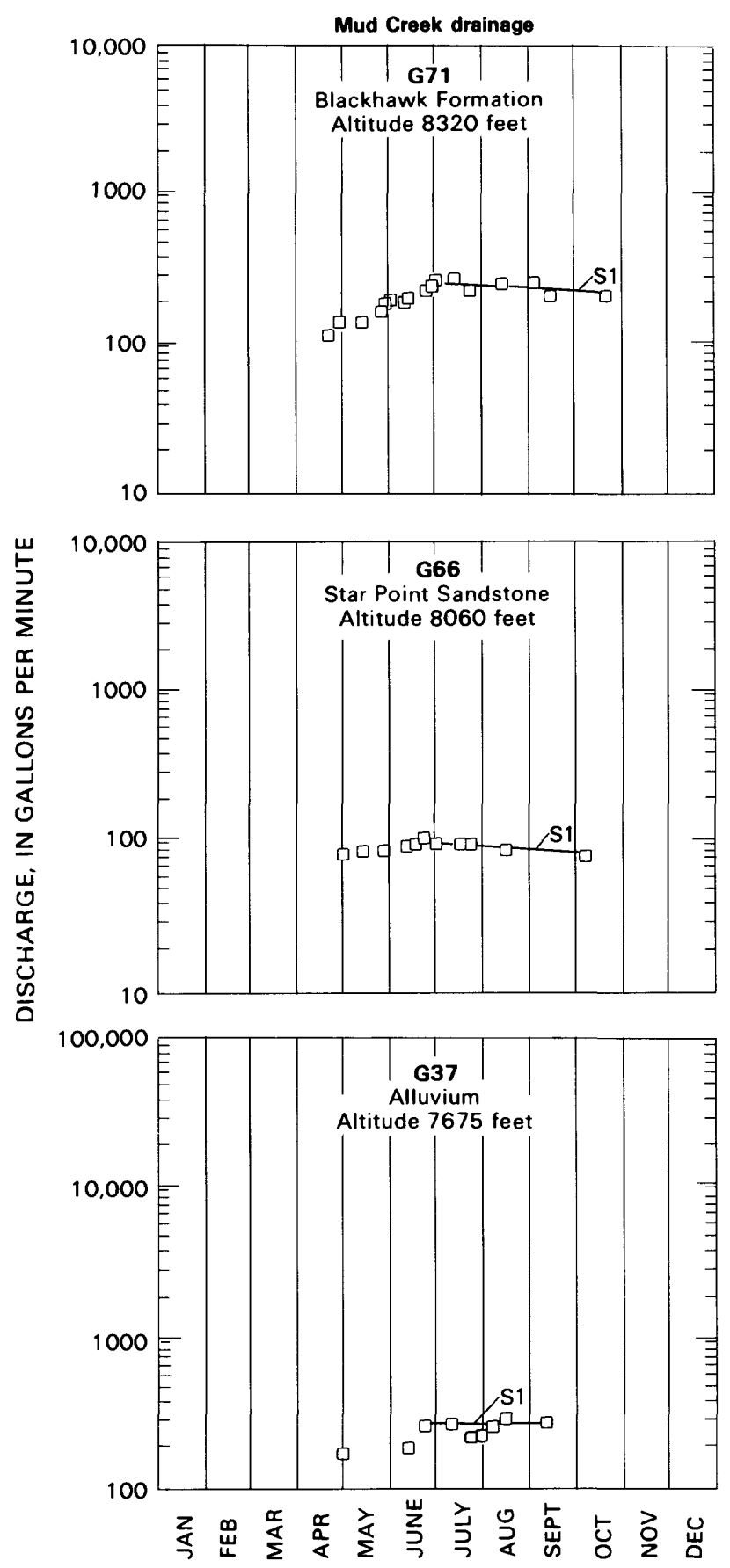

Figure 12. (above and facing page) Recession hydrographs of selected springs and a well in the Mud Creek and Beaver Creek drainages and the Soldier Creek area, 1980.

seasonal fluctuation, whereas the discharges of springs issuing from the Blackhawk and North Horn Formations have a smaller seasonal response to snowmelt. Spring G90, which issues from the Flagstaff Limestone, had a discharge of 112 gallons per minute on June 5, 1980, but the spring was dry on September 11, 1980. In comparison, spring G89, which issues from the North Horn Formation, 

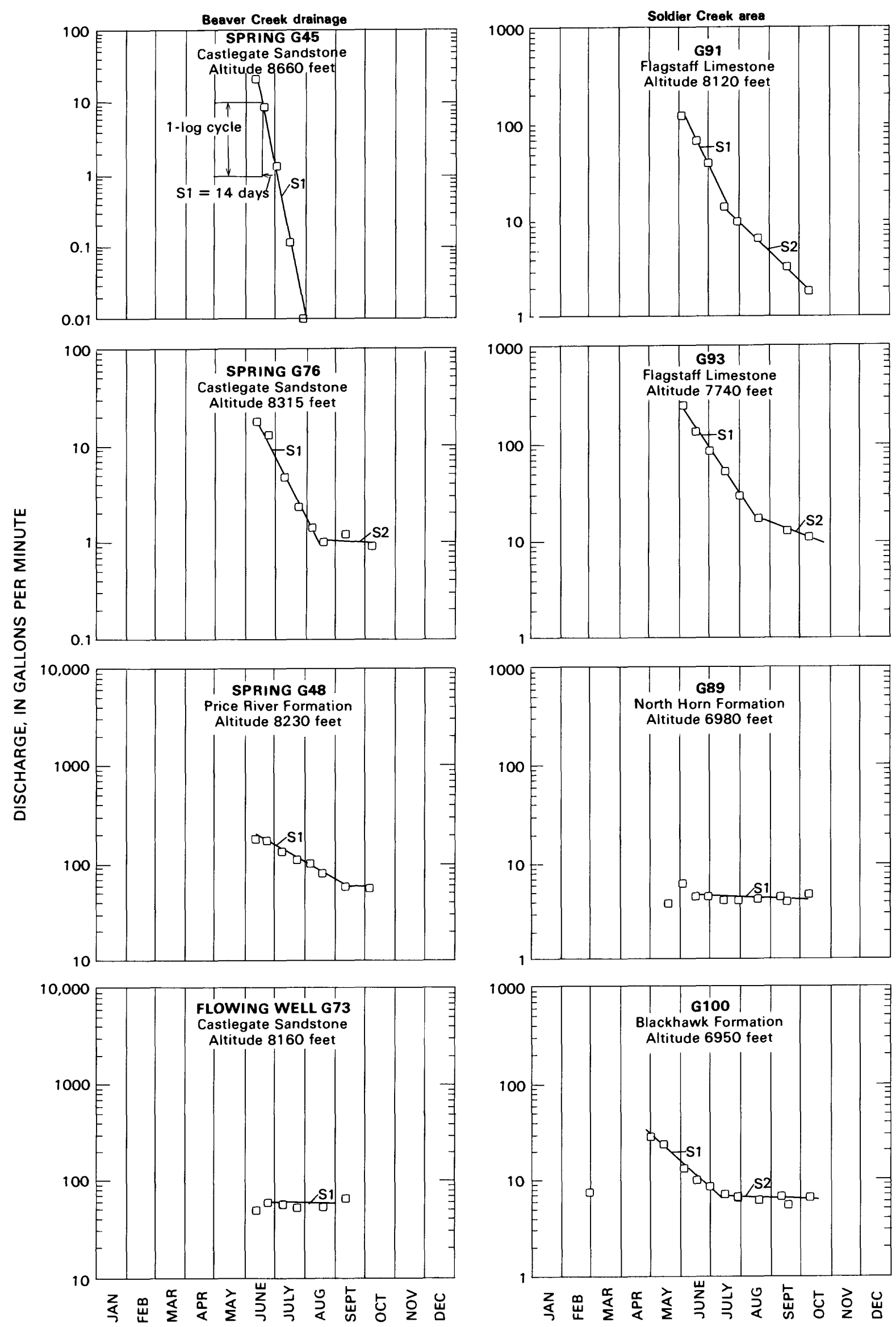
had a discharge of 6.3 gallons per minute on June 5, 1980 , and 4.1 gallons per minute on September 11, 1980. The slopes of the recession curves for discharge generally increase directly with altitude, indicating that the springs at the higher altitudes have a greater seasonal variability. The initial slopes of the recession curves ( 1 1, table 5 ) for springs issuing from the Colton Formation and the Flagstaff Limestone ranged from 24 to 115 days per log cycle. The corresponding initial slopes of the recession curves for the two springs issuing at lower altitudes from the Blackhawk and North Horn Formations varied from 116 to greater than 365 days per $\log$ cycle. The initially large discharge from springs issuing from the Flagstaff Limestone after snowmelt and the large seasonal variability of the discharge are indicative of a cavernous limestone aquifer that has great hydraulic diffusivity and a small storage coefficient.

Springs G89 and G100 issue from the North Horn and Blackhawk Formations, respectively, at altitudes either below or within the range of the potentiometric surface in the Blackhawk. The potentiometric surface at two wells and a mine completed in the Blackhawk ranged from 6,896 to 7,035 feet above sea level. Springs G89 and G100 had the smallest recession indexes of all the springs in the Soldier Creek area. These small recession indexes may occur because both springs probably are sustained by water from the Blackhawk and storage in the Blackhawk does not change in response to seasonal snowmelt as rapidly as storage in the Flagstaff Limestone.

\section{Discharge From Mines}

Mine discharges, as reported from mining-company records, are compiled in table 6. Except for the Clear Creek Mine, all records were estimated from infrequent measurements. The discharge from the Clear Creek Mine was continuously monitored by the U.S. Geological Survey during the 1980 water year. The estimated total discharge from mines in the study area during 1980 was about 2,800 acre-feet.

Table 6. Discharge of water from coal mines

Name of mine: See plate 1 for location.

Discharge: All discharges obtained from records of mining companies, except for Clear Creek Mine where the discharge was continuously monitored by the U.S. Geological Survey.

\begin{tabular}{lccl}
\hline Name of mine & Period of discharge & $\begin{array}{c}\text { Discharge } \\
\text { (acre-feet) }\end{array}$ & Receiving stream \\
\hline Belına No 1 & 1 1-80 to $7-2480$ & 0 & Eccles Canyon \\
Clear Creek & 72580 to $12-3180$ & 55 & Mud Creek \\
Soldıer Creek & $10-1-79$ to $9-30-80$ & 300 & Soldrer Creek \\
Sunnyside & $12-1-80$ to $12-31-80$ & 15 & Grassy Trail Creek \\
Plateau & $1-1-80$ to $12-31-80$ & 1.000 & Mud Water Creek \\
King & $1-1-80$ to $12-31-80$ & 75 & Cedar Creek \\
Horse Canyon & $1-180$ to $12-31-80$ & 1.100 & Horse Canyon \\
Braztah & $1-1-80$ to $12-31-80$ & 230 & (1) \\
\hline
\end{tabular}

'Entıre discharge used withın mine.

\section{Ground Water-Surface Water Relationships}

The base flow in an uncontrolled stream usually is ground water that is discharged to the stream. The volume of water so discharged largely is dependent on the capacity of an aquifer to store and transmit water, the gradient between the aquifer and the stream, the volume of recharge to the aquifer, and the hydraulic connection of the aquifer to the stream. In the Soldier Creek drainage, the Flagstaff Limestone, which has a large hydraulic diffusivity, sustains most of the streamflow during the summer months following snowmelt, but is thereafter rapidly depleted of water. In contrast, the Blackhawk Formation has a small hydraulic diffusivity and sustains the base flow of Soldier Creek during the fall and winter months.

\section{Recession Curves}

Streamflow begins to recede after snowmelt or other periods of recharge. The relationship of the recession curve to the hydraulic characteristics of an unconfined aquifer has been studied by many investigators. Rorabaugh $(1960,1964)$ and Rorabaugh and Simons (1966) developed equations which relate the slope of the recession curve to the transmissivity and storage coefficient of the aquifer,

where

$$
\frac{T}{a^{2} S}=\frac{0.933}{t / \log \text { cycle }}
$$

$T$ is the transmissivity of the aquifer, in feet squared per day,

$a$ is the average distance to the hydrologic divide, in feet.

$S$ is the storage coefficient of the aquifer (dimensionless), and

$t$ is the time required for the discharge to recede through one log cycle, in days.

Equation 1 is an approximate solution to a more complicated function, being valid only when sufficient time has elapsed after the period of recharge for the recession curve to become a straight line in a semilog plot.

In the development of the original equation, Rorabaugh (1960, p. 315) assumed that the drainage basin is underlain by a homogeneous isotropic aquifer, distance from stream to ground-water boundaries are equal throughout the basin, the initial ground-water level is everywhere horizontal and at stream level, and the aquifer is fully penetrated by the stream. These conditions are seldom met in most hydrologic systems, but the numerical value of the ratio $T / \mathrm{a}^{2} S$ can be used as a basin characteristic (Rorabaugh and Simons, 1966, p. 12) to describe geohydrologic conditions using streamflow 
records (Trainer and Watkins, 1974). The slopes of the recession curves (days per log cycle, which is equivalent to the indexes of S1 or S2 in table 5 that were computed for springs) for streams in the Price River basin provide a characteristic that may be used for identifying impacts of mining on the natural ground water-surface water relationships.

Climatic conditions during 1980 were suitable for study of the recession characteristics of streams, especially in the Book Cliffs. Snowmelt in the Book Cliffs began about mid-April, and by the middle of May most of the snowpack had melted. The summer was dry, and streamflow recessions were not interrupted by any recharge until about the middle of August.

Little is known about hydraulic characteristics of aquifers in the Price River basin. Seepage studies and monitoring of the flow of springs indicate that water is being discharged to streams in some areas by more than one aquifer and that the hydraulic characteristics of the aquifers are considerably different. The flow of Soldier Creek was gaged at site S59 near the base of the Blackhawk Formation, and the flow of 11 springs issuing from the Flagstaff Limestone and Blackhawk Formation were monitored from early June until October. A semilog plot of the discharge of Soldier Creek at the gaging station indicates that the discharge began to follow a straight line about the first of June. The relationship of the recession index of Soldier Creek to that of the discharge of the springs was studied by two different procedures.

The first procedure consisted of making a semilog plot of the composite flows of the springs issuing from the Flagstaff Limestone and comparing it with the hydrograph of the flow in Soldier Creek. As show in figure 13, the curves for the springflow and the flow of Soldier Creek are almost parallel. The recession index for both flows is about 65 days per log cycle.

The second procedure involved separation of the hydrograph for Soldier Creek into ground-water components. Water-quality relationships were used to separate the contribution of the Flagstaff Limestone from that of the Blackhawk Formation, Castlegate Sandstone, and Price River and North Horn Formations. (See section on Hydrology of Soldier Creek area.) As indicated in figure 13, the discharge from the Flagstaff is the major source of streamflow during the late spring and early summer. At about the middle of August, the recession curve for Soldier Creek changes abruptly in slope. At that time, the discharge from the Flagstaff has receded to a point where the flow from the Blackhawk Formation, Castlegate Sandstone, and Price River and North Horn Formations has become a large enough percentage of the total flow so that it begins to dominate the shape of the recession curve for the stream.
Riggs (1964, p. 353-354) discussed the recession curves of streams where two aquifers were contributing to the streamflow. He showed how the combined runoff from two unlike aquifers can produce a recession curve with two slopes. Trainer and Watkins (1974) also compiled recession indexes for streams that had two slopes and labeled them as compound recession curves. In the instance of Soldier Creek, there are two aquifers with different recession indexes, and one of the aquifers has two recession indexes.

Recession indexes also were computed for Coal, Dugout, and Willow Creeks, all of which have geologic and physiographic settings as well as climatic patterns that are similar to those of Soldier Creek. The recession indexes compiled for sites on these streams ranged from 56 to 63 days per log cycle during 1980, compared to 67 for Soldier Creek (table 7). These results indicate the similarity of geohydrologic conditions in different basins in the Book Cliffs.

As noted above, the recession index of 67 days per log cycle for Soldier Creek represents only the recession characteristics of the Flagstaff Limestone. For all the creeks, the streamflow record during the fall was affected by periods of recharge (fig. 13) so that it was not possible to compute a recession index for the second recession, which is dominated by flow from the Blackhawk Formation, Castlegate Sandstone, and Price River and North Horn Formations.

The year-to-year consistency of the recession indexes was evaluated using the streamflow records for the 1971-80 water years for the gaging station at site S37.3 on Willow Creek (fig. 1). That record was used because all other stations in the Book Cliffs have only 1 or 2 years of record. Climatic conditions occurring in 8 of the 10 years were suitable for evaluating the recession characteristics. The indexes averaged 49 days per log cycle and the standard error of the distribution was 2.1 days. Thus, for a 90-percent probability, the recession index will be in the range from 45 to 53 days $(49 \pm 1.9 \times 2.1$ days $)$.

In the Wasatch Plateau, the recession characteristics of the streams were highly variable from year to year and it was difficult to determine straight-line segments of the streamflow hydrographs. The reason for this may be that the snow in the Wasatch Plateau may remain as much as 3 months before it fully melts, considerably longer than in the Book Cliffs.

\section{Chemical Quality}

The concentration of dissolved solids in ground water in the Wasatch Plateau and Book Cliffs is shown in plate 1 . The map was made by updating a similar map prepared by Waddell and others $(1981$, pl. 7) with additional data collected during 1979-80 at 51 springs, wells, 


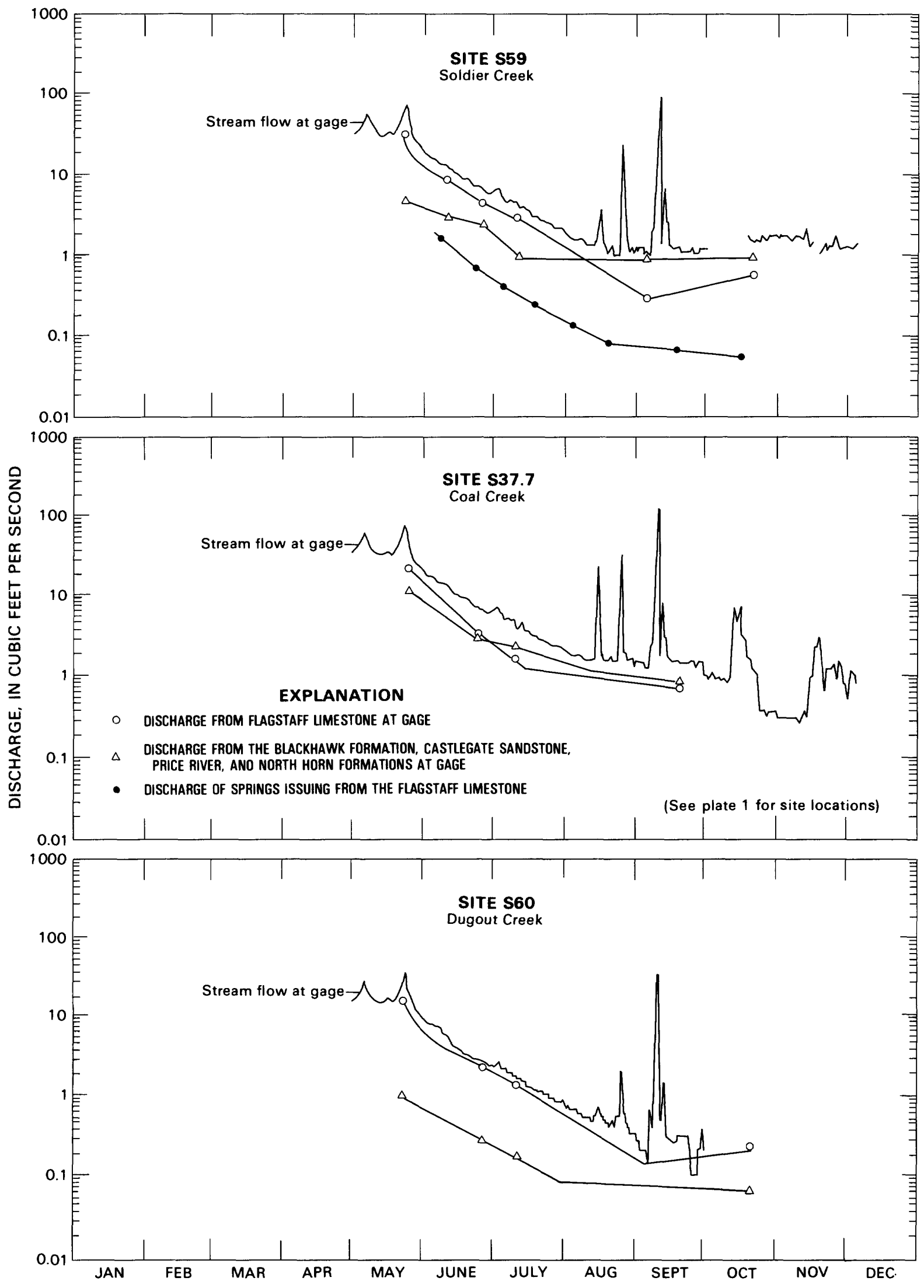

Figure 13. Hydrographs of streams in the Soldier Creek area and separation of base flow from the Flagstaff Limestone and the Blackhawk Formation, Castlegate Sandstone, and Price River and North Horn Formations, 1980. 
and mines. Because of the emphasis in this study on the coal-field areas, all samples were collected from formations younger than the Mancos Shale. Thus, the data in plate 1 provide a general areal description of the concentration of dissolved solids and the chemical composition of ground water only in the shallowest aquifers.

In most of the Wasatch Plateau, the concentration of dissolved solids was less than 500 milligrams per liter, and the principal chemical constituents were calcium and bicarbonate. At the highest altitudes along the northwest boundary of the study area, near where the Flagstaff Limestone crops out, the concentration of dissolved solids was less than 250 milligrams per liter. In the Mud Creek drainage and Beaver Creek area the concentrations of dissolved solids generally were less than 500 milligrams per liter, and some springs discharged water containing less than 100 milligrams per liter.

In the Book Cliffs, the concentration of dissolved solids ranged from 250 to more than 1,000 milligrams per liter. The concentration of dissolved solids, as well as the predominant chemical constituents, vary with the formation and areally within formations. The concentration of dissolved solids in water from the Flagstaff Limestone, which caps much of the Book Cliffs, ranged from 250 to 500 milligrams per liter, whereas the concentration of dissolved solids in the underlying formations, including the North Horn and Blackhawk Formations, ranged from 500 to more than 1,000 milligrams per liter. The principal chemical constituents in water from the Flagstaff are calcium and bicarbonate. Water from the Blackhawk is of variable chemical composition, generally of a mixed type with no single dominant cation or anion.

The concentration of dissolved solids of water in the Blackhawk Formation may be affected by the Mancos Shale, which yields water containing relatively large concentrations of sodium and sulfate (Mundorff, 1972, p. 14, and Waddell and others, 1981, p. 4). The specific conductance of water from springs G99 and G99.5 (fig. 2 and plate 1) which issue near the Blackhawk-Mancos contact in the Soldier Creek area, indicated that the concentration of dissolved solids was about 1,600 and 2,000 milligrams per liter, respectively, and the dominant ions were sodium and sulfate. In areas where the Mancos is affecting the quality of water in the Blackhawk, sodium and sulfate ions generally dominate the chemical composition. This is attributed to the interbedding of the Mancos and Blackhawk, which occurs in parts of the Book Cliffs where the Star Point Sandstone is not present. The chemical composition of water discharging from the Blackhawk Formation into Soldier, Coal, and Dugout Creeks is remarkably similar. Apparently the gaging stations on these creeks are far enough upstream from the contact between the Blackhawk and the Mancos Shale that the ground water entering the streams upstream
Table 7. Recession characteristics for selected streams in the Book Cliffs, 1980

Site No.: See figure 1 for location.

\begin{tabular}{llc}
\hline Site No. & \multicolumn{1}{c}{ Stream } & $\begin{array}{c}\text { Slope of recession (S1) } \\
\text { (days per log cycie) }\end{array}$ \\
\hline S37.3 & Willow Creek & 61 \\
S37.4 & do, & 63 \\
S37.7 & Coal Creek & 63 \\
S59 & Soldier Creek & 67 \\
S60 & Dugout Creek & 56 \\
& & Average \\
\hline
\end{tabular}

from the gages is not affected by solution of minerals in the Mancos (U.S. Geological Survey, 1980, p. 262-272).

The relationship of the concentration of the major dissolved inorganic constituents to discharge during the recession of streamflow at gaging station S59 on Soldier Creek is illustrated in figure 14. The effects of overland runoff from snowmelt and thunderstorms have been excluded from the relationship shown in figure 14 so that the chemical composition of the streamflow represents only the ground-water component of streamflow. The average chemical composition of water from seven springs issuing from the Flagstaff Limestone and from a spring issuing from a mine draining the Blackhawk Formation are compared in figure 14 with the chemical composition of the streamflow. When the discharge of the stream is small, the chemical composition trends toward that of water from the Blackhawk Formation; when the stream discharge is large, the composition trends toward that of water from the Flagstaff Limestone; at intermediate stream discharges, the composition is a mixture of the two sources of ground water.

\section{Geochemical Relationships}

The chemical equilibria of ground water in the study area are typical of sedimentary rocks. The principal chemical constituents are derived by solution of carbonate minerals in limestones and dolomites and possibly by solution of gypsum and anhydrite. Solubility indexes for calcite, dolomite, gypsum, and anhydrite are compiled in table 8 based on computations using the WateQ2 computerized model developed by Ball, Norstrom, and Jenne (1980). The solubility indexes do not indicate that the minerals actually occur in the aquifer that is the source of water, but they are indicative of the equilibrium state if, in fact, the minerals were present. The solubility indexes in table 8 are in logarithmic form. Thus, for solubility indexes less than 0 , the water would be considered to be undersaturated with respect to the specified mineral; for solubility indexes equal to 0 , the water would be considered saturated or at equilibrium 


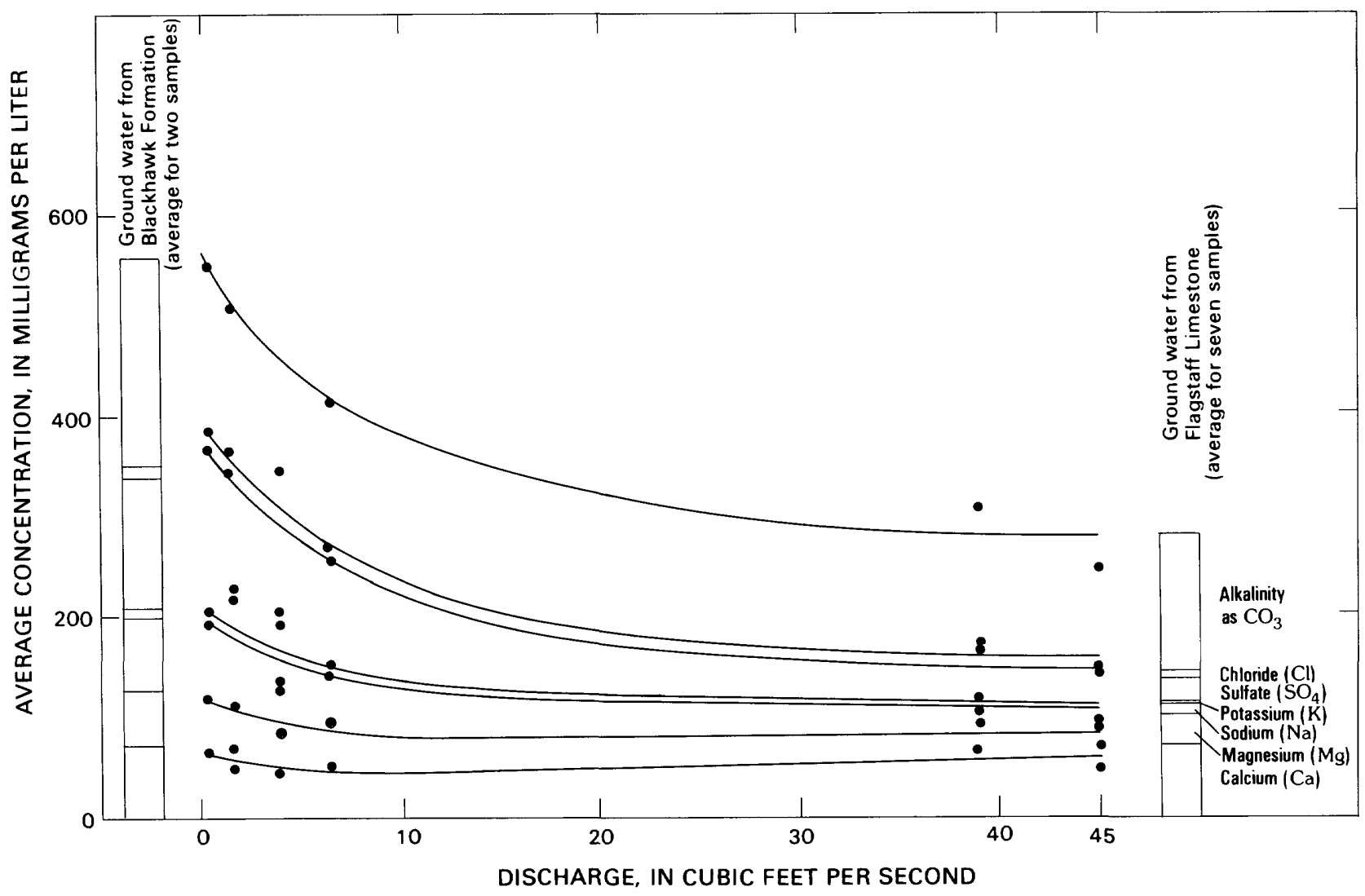

Figure 14. Relationship between the discharge of Soldier Creek and the concentration of dissolved chemical constituents in Soldier Creek and in ground water, 1979-80.

with respect to the specified mineral; and for solubility indexes greater than 0 , the water would be considered supersaturated with respect to a given mineral.

As the data in table 8 indicate, most water in the study area is near saturation with respect to calcite. Saturation occurs even in waters with considerable differences in chemical composition.

In the Wasatch Plateau, most springs discharge water of similar composition, regardless of source. The solubility indexes are similar with respect to most minerals, and the principal chemical constituents generally are calcium and bicarbonate. Magnesium and sulfate may occur in moderate concentrations, but they seldom are the dominant ions. In the Book Cliffs virtually all the water issuing from the Blackhawk Formation is saturated with respect to calcite and in some instances with respect to dolomite.

Three chemical analyses that are typical of ground water in the study area are compiled below:

\begin{tabular}{|c|c|c|c|c|c|c|c|c|c|c|}
\hline \multicolumn{10}{|c|}{ Concentration, in milligrams per liter } & \multirow{2}{*}{$\begin{array}{c}\text { Solubility } \\
\text { indexes } \\
\text { for calcite }\end{array}$} \\
\hline Site No. & $\begin{array}{c}\text { Calcium } \\
\text { (Ca) }\end{array}$ & $\begin{array}{c}\text { Magnesium } \\
(\mathrm{Mg}) \\
\end{array}$ & $\begin{array}{l}\text { Sodium } \\
(\mathrm{Na})\end{array}$ & $\begin{array}{c}\text { Potassium } \\
(\mathrm{K})\end{array}$ & $\begin{array}{c}\text { Sulfate } \\
\left(\mathrm{SO}_{4}\right)\end{array}$ & $\begin{array}{c}\text { Chloride } \\
(\mathrm{Cl}) \\
\end{array}$ & $\begin{array}{c}\text { Alkalinity } \\
\text { (as } \mathrm{CACO}_{3} \text { ) }\end{array}$ & $\begin{array}{l}\text { Dissolved solids, } \\
\text { sum of constituents }\end{array}$ & $\mathrm{pH}$ & \\
\hline G25 & 7.5 & 1.8 & 2.5 & 0.3 & 2.3 & 2.6 & 16 & 40 & 5.5 & -4.0 \\
\hline G89 & 30 & 28 & 180 & 4.2 & 39 & 49 & 480 & 629 & 7.5 & -0.24 \\
\hline G94 & 89 & 20 & 9.9 & 1.4 & 20 & 3.9 & 310 & 339 & 7.3 & .068 \\
\hline
\end{tabular}

Spring G25 discharges from a soil developed on the Blackhawk where the chemical equilibria are controlled primarily by the partial pressure of carbon dioxide in the atmosphere. The water has a dissolved-solids concentration of only 40 milligrams per liter, the $\mathrm{pH}$ is
5.5 , and the water is significantly undersaturated with respect to calcite. If this water eventually percolates back into the ground and enters a zone containing calcite or dolomite, those minerals will be dissolved. The degree of solution will depend largely on the availability of 
Table 8. Summary of solubility indexes for ground water

Site No.: See plate 1 for location.

Solubility indexes: Log (Activity product/solubility constant).

Geologic unit: ALVM, Alluvium: CLTN. Colton Formation: FLGF. Flagstaff Limestone: NRHR. North Horn Formation. PCRV, Price River Formation: CSLG. Castlegate Sandstone: BCKK. Blackhawk Formation: SRPN. Star Point Sandstone.

\begin{tabular}{|c|c|c|c|c|c|c|}
\hline \multirow[b]{2}{*}{$\begin{array}{l}\text { Site } \\
\text { No. }\end{array}$} & \multirow[b]{2}{*}{$\begin{array}{c}\text { Geologic } \\
\text { unit }\end{array}$} & \multirow[b]{2}{*}{$\mathrm{pH}$} & \multicolumn{4}{|c|}{ Solubility index } \\
\hline & & & Calcite & Dolomite & Gypsum & Anhydrite \\
\hline G12 & PCRV & _- & -0194 & -1090 & -2269 & -2667 \\
\hline $\mathrm{G} 13$ & CSLG & - & -141 & -886 & -2074 & -2472 \\
\hline G14 & PCRV & - & -274 & -1276 & -2116 & -2516 \\
\hline G15 & NRHR & 77 & 192 & -104 & -2316 & -2733 \\
\hline G17 & FLGF & - & -118 & -583 & -2339 & -2.746 \\
\hline G25 & (1) & 56 & -3997 & -8537 & -3011 & -3397 \\
\hline G27 & CSLG & - & -.133 & -1084 & -1.691 & -2103 \\
\hline G34 & $B C K K$ & 73 & 047 & -696 & -1515 & -1926 \\
\hline G35 & BCKK & 69 & -491 & -1672 & -1655 & -2038 \\
\hline G36 & BCKK & 65 & -1379 & $\begin{array}{l}-3564 \\
\end{array}$ & -2.180 & $\begin{array}{l}-2.566 \\
-56\end{array}$ \\
\hline $\mathrm{G} 37$ & ALVM & 71 & 013 & -256 & -1580 & -1900 \\
\hline G39 & BCKK & 69 & -444 & -1717 & -1899 & -2292 \\
\hline G44 & PCRV & 75 & 006 & -281 & -2097 & -2490 \\
\hline G45 & CSLG & 73 & -069 & -1092 & -1856 & -2272 \\
\hline G46 & PCRV & - & -276 & -1278 & -1644 & -2063 \\
\hline G48 & PCRV & - & -094 & -705 & -1977 & -2392 \\
\hline G62 & ALVM & 73 & -224 & -1283 & -1832 & -2219 \\
\hline G63 & ALVM & 71 & -160 & -1264 & -2139 & -2522 \\
\hline G64 & BCKK & 73 & -054 & -1024 & -2023 & -2411 \\
\hline G65 & BCKK & - & -309 & -1521 & -1907 & -2340 \\
\hline G66 & SRPN & 75 & 117 & -105 & -1525 & -1904 \\
\hline G69 5 & BCKK & 77 & .048 & -591 & -2597 & $\begin{array}{l}-1.026 \\
-3.026\end{array}$ \\
\hline$G 71$ & BCKK & 72 & -198 & -827 & -1334 & -1.737 \\
\hline G73 & CSLG & 69 & -627 & -1981 & -1352 & -1761 \\
\hline G76 & CSLG & - & -368 & $\begin{array}{r}-1672 \\
\end{array}$ & -1.580 & $\begin{array}{l}-1991 \\
\end{array}$ \\
\hline G89 & NRHR & 75 & -024 & -023 & -2134 & -2515 \\
\hline G90 & FLGF & 72 & -113 & -432 & $\begin{array}{r}-1947 \\
\end{array}$ & -2336 \\
\hline G91 & FLGF & 74 & 086 & $\begin{array}{r}-178 \\
-178\end{array}$ & $\begin{array}{r}1938 \\
-19\end{array}$ & -2323 \\
\hline G92 & FLGF & 74 & -011 & -406 & -1992 & -2382 \\
\hline G93 & FLGF & 83 & 848 & 1435 & -2040 & -2376 \\
\hline G94 & FLGF & 73 & 068 & -506 & -1913 & -2323 \\
\hline 695 & FLGF & 73 & -087 & -398 & -1942 & -2332 \\
\hline G96 & CLTN & 72 & -197 & -571 & -2123 & -2501 \\
\hline G97 & FLGF & 73 & -042 & -.440 & -1810 & -2214 \\
\hline G98 5 & BCKK & 75 & 317 & 685 & -1814 & -2.111 \\
\hline G100 & BCKK & 72 & .008 & -080 & -1006 & -1.390 \\
\hline G110 & BCKK & 74 & -048 & -115 & -1389 & -1756 \\
\hline G110 4 & BCKK & 75 & 011 & 198 & -1130 & -1467 \\
\hline G1106 & BCKK & 73 & -004 & 174 & -893 & -1230 \\
\hline G111 & BCKK & 72 & 053 & -142 & -1261 & -1650 \\
\hline G114 & BCKK & 76 & 287 & 789 & $\begin{array}{r}-1201 \\
-378\end{array}$ & $\begin{array}{r}-743 \\
-743\end{array}$ \\
\hline G115 & BCKK & 8.0 & 759 & +742 & -.276 & $\begin{array}{l}-633 \\
\end{array}$ \\
\hline
\end{tabular}

carbon dioxide in the aquifer. In an aquifer that is open to the atmosphere (unconfined conditions), solution of carbonate minerals will be greater than in a aquifer closed to the atmosphere (confined conditions) where carbon dioxide is not being replenished.

The chemical equilibria of the water from spring G94, which issues from the Flagstaff Limestone, are typical of water that has had considerable contact with calcite. The water has a dissolved-solids concentration of 339 milligrams per liter, the $\mathrm{pH}$ is 7.3 , and the water is saturated with respect to calcite. This indicates that the water in the Flagstaff at spring G94 is under unconfined conditions and carbon dioxide is being replenished in the water. In confined aquifers, water that has had considerable contact with calcite generally will have $\mathrm{pH}$ values greater than 8.0.

Spring G89, which issues from the North Horn Formation, discharges water that is almost saturated with respect to calcite as well as dolomite (saturation indexes of -.024 and -.023 , respectively). The predominant dissolved ions, however, are sodium and bicarbonate. Water saturated with respect to calcite, but with sodium and bicarbonate as the dominant ions, typically results from sulfate reduction or cation exchange.

Sulfate reduction commonly occurs in the presence of bacteria and organic matter. Carbon dioxide and hydrogen sulfide are generated as a product; and the carbon dioxide in water forms carbonic acid, which in turn causes calcite solution. Water of this type maintains large concentrations of bicarbonate and small concentrations of calcium and sulfate. For a given $\mathrm{pH}$, large concentrations of bicarbonate repress the concentration of calcium. Odors from hydrogen sulfide are prevalent in waters formed in this way.

Water from spring G89 had an odor of hydrogen sulfide as well as small concentrations of calcium. The only formation in the Book Cliffs that contains appreciable quantities of sulfate is the Blackhawk Formation. Thus, if the process of sulfate reduction is resulting in the sodium bicarbonate water, then the most likely source would be upward movement from the Blackhawk Formation.

Cation exchange can produce sodium bicarbonate waters in an aquifer that contain calcite and clay minerals with exchangeable sodium ions. In this process, calcite continues to be dissolved from the aquifer as along as exchangeable sodium ions are available in the clay matrix to exchange with the calcium ions. There are clay layers in the North Horn Formation which could provide the exchange matrix for water that might seep through the North Horn. However, because of the presence of hydrogen sulfide in water from spring G89, and consideration of water levels in a nearby well and seepage gains along Soldier Creek, the process of cation exchange is less likely than that of sulfate reduction in explaining the chemical equilibria of water discharging from spring G89. See discussion in section on "Discharge to streams" regarding upward movement of water from the Blackhawk Formation.

\section{Trace Metals}

Chemical analyses for trace metals in ground water in the study area included the following dissolved metals: boron, chromium, copper, iron, lead, mercury, zinc, strontium, lithium, and selenium (table 9). The concentrations of most metals were quite small throughout the study area, the most notable exceptions being iron and strontium. Water from spring G66, which issues from the Star Point Sandstone near the mouth of Eccles Canyon, and from mine G71, which discharges from the Blackhawk Formation, had concentrations of iron ranging from 720 to 880 micrograms per liter. Flowing well G73, which discharges from the Castlegate Sandstone, had an iron concentration of 1,600 micrograms per liter.

The concentration of strontium ranged from 30 to 3,600 micrograms per liter. The concentration of stron- 
Table 9. Chemical analyses for dissolved metals in water from selected springs, mines, and a well in the Price River basin Site No.: See plate 1 for location.

Geologic unit: ALVM, Alluvium: CLTN, Colton Formation; FLGF, Flagstaff Limestone; NRHR, North Horn Formation, PCRV, Price River Formation; CSLG, Castlegate Sandstone: BCKK, Blackhawk Formation; SRPN. Star Point Sandstone. pH: Values are field measurements.

\begin{tabular}{|c|c|c|c|c|c|c|c|c|c|c|c|c|c|c|c|c|c|c|}
\hline \multirow[b]{2}{*}{ Site No. } & \multirow[b]{2}{*}{$\begin{array}{l}\text { Geologic } \\
\text { unit }\end{array}$} & \multirow[b]{2}{*}{ Date } & \multirow[b]{2}{*}{ 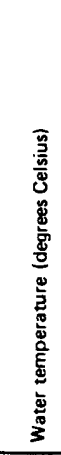 } & \multirow[b]{2}{*}{ 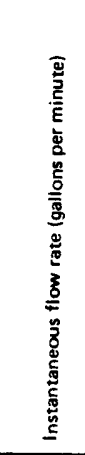 } & \multirow[b]{2}{*}{ 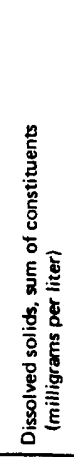 } & \multirow[b]{2}{*}{ 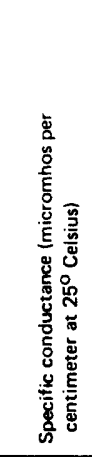 } & \multirow[b]{2}{*}{$\frac{I}{a}$} & \multicolumn{11}{|c|}{ Micrograms per liter } \\
\hline & & & & & & & & 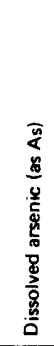 & 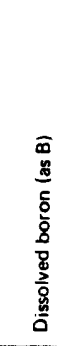 & 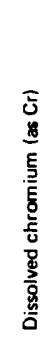 & 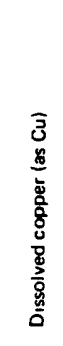 & 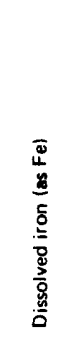 & 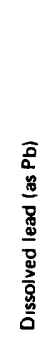 & 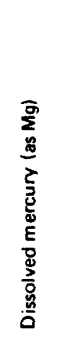 & 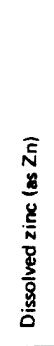 & 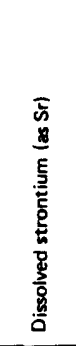 & 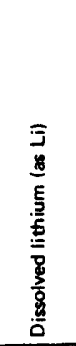 & 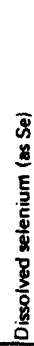 \\
\hline \multirow[t]{2}{*}{$\mathrm{G} 12$} & PCRV & $8 \cdot 10-79$ & 9.8 & 46 & 285 & 470 & - & $<1$ & 30 & 0 & - & $<10$ & - & - & 20 & 100 & 20 & 0 \\
\hline & & $7-23-80$ & 7.2 & 5.9 & 277 & 482 & 7.2 & $<1$ & 50 & 0 & $<2$ & $<10$ & $<1$ & 1.1 & 6 & 110 & 10 & 0 \\
\hline $\mathrm{G} 13$ & CSLG & $8-10-79$ & 8.3 & - & 295 & 473 & - & $<1$ & 20 & 20 & - & $<10$ & - & - & 6 & 110 & 20 & 0 \\
\hline & & 7.23 .80 & 7.2 & 13 & 302 & 506 & 7.2 & 1 & 10 & 7 & $<2$ & $<10$ & 2 & .9 & 6 & 110 & 10 & 0 \\
\hline G14 & PCRV & $7 \cdot 23.80$ & 6.9 & 14 & 231 & 407 & 7.3 & 1 & 100 & 0 & $<2$ & $<10$ & 2 & $<.1$ & 6 & 110 & 8 & 0 \\
\hline G15 & NRHR & $7-28-80$ & 5.6 & 50 & 246 & 490 & 7.7 & 1 & 100 & 1 & $<2$ & $<10$ & 2 & $<.1$ & 10 & 100 & 7 & 0 \\
\hline G17 & FLGF & 7.24 .80 & 6.4 & 14 & 289 & 505 & 7.3 & 1 & 30 & 0 & $<2$ & $<10$ & $<1$ & $<.1$ & 6 & 650 & 10 & 2 \\
\hline G24 & CSLG & 8. 1.80 & 4.9 & 49 & 815 & 1,190 & $<1$ & 1 & 190 & 0 & $<2$ & $<10$ & 2 & $<.1$ & 20 & 720 & 50 & 2 \\
\hline $\mathrm{G} 25$ & $(1)$ & 8. 2.79 & 8.3 & .60 & 54 & 51 & 5.6 & 1 & 20 & 10 & - & 230 & - & - & 40 & 30 & 10 & 0 \\
\hline & & $7 \cdot 28.80$ & 8.2 & .34 & 40 & 67 & 5.5 & 1 & 20 & 0 & 2 & 250 & 2 & 1.5 & 20 & 30 & 4 & 0 \\
\hline $\mathrm{G} 27$ & CSLG & $7.28-80$ & 6.0 & 22 & 278 & 473 & 7.3 & $<1$ & 60 & 0 & $<2$ & $<10$ & $<1$ & $<.1$ & 10 & 130 & 10 & 1 \\
\hline G28 & BCKK & 8. 9.79 & 7.1 & 15 & 374 & 589 & - & $<1$ & 20 & 10 & - & 30 & - & - & 20 & 160 & 30 & 1 \\
\hline G31 & PCRV & $8-10-79$ & 8.4 & .42 & 66 & 85 & - & 1 & 10 & 20 & - & $<10$ & - & - & 7 & 50 & 20 & 0 \\
\hline G32 & BCKK & 8. $9 \cdot 79$ & 7.5 & - & 233 & 385 & - & $\leq 1$ & 30 & 10 & - & $<10$ & - & - & 30 & 140 & 20 & 2 \\
\hline G34 & BCKK & $8-10.79$ & 6.1 & 2.1 & 374 & 654 & 7.3 & $<1$ & 10 & 20 & - & $<10$ & - & - & 9 & 160 & 30 & 2 \\
\hline & & 7.24 .80 & 6.8 & 42 & 375 & 635 & 7.2 & 1 & 60 & 0 & $<2$ & $<10$ & $<1$ & 1.8 & 4 & 170 & 20 & 2 \\
\hline G35 & BCKK & 8. 9.79 & 86 & - & 301 & 480 & 6.9 & $<1$ & 30 & 10 & - & $<10$ & - & - & 7 & 180 & 20 & 1 \\
\hline & & $7.24-80$ & 84 & 12 & 293 & 487 & 7.2 & 1 & 60 & 0 & $<2$ & $<10$ & $<1$ & $<.1$ & 20 & 170 & 10 & 1 \\
\hline G36 & BCKK & 8. $9-79$ & 8.3 & - & 167 & 293 & 6.5 & $<1$ & 20 & 10 & - & 20 & - & - & 40 & 110 & 20 & 1 \\
\hline G37 & ALVM & $8-15-79$ & 144 & 198 & 410 & 631 & 7.1 & $<1$ & 50 & 10 & - & 20 & - & - & 4 & 420 & 40 & 0 \\
\hline & & $7 \cdot 25-80$ & 141 & 235 & 348 & 654 & 7.0 & 2 & 140 & 1 & $<2$ & $<10$ & 2 & $<.1$ & 9 & 410 & 30 & 0 \\
\hline G39 & BCKK & $8-15-79$ & - & - & 297 & 523 & 6.9 & $<1$ & 20 & 20 & - & $<10$ & - & - & 10 & 160 & 30 & 1 \\
\hline G41 & ALVM & 7.24 .80 & 138 & 26 & 301 & 543 & 7.2 & $<1$ & 70 & 0 & $<2$ & $<10$ & $<1$ & .3 & $<3$ & 580 & 30 & 0 \\
\hline G44 & PCRV & $7 \cdot 29-80$ & 7.7 & 33 & 267 & 502 & 7.5 & $<1$ & 110 & 0 & $<2$ & $<10$ & 3 & $<.1$ & $<3$ & 220 & 10 & 1 \\
\hline G45 & CSLG & 7.29 .80 & 56 & 01 & 284 & 522 & 7.3 & 1 & 100 & 0 & $<2$ & $<10$ & 2 & $<.1$ & $<3$ & 120 & 9 & 0 \\
\hline G46 & PCRV & $7 \cdot 24-80$ & 5.3 & 15 & 263 & 425 & 7.3 & 1 & 30 & 0 & 3 & $<10$ & $<1$ & .7 & 5 & 140 & 10 & 1 \\
\hline G48 & PCRV & $7 \cdot 24-80$ & 5.7 & 111 & 293 & 500 & 7.3 & $<1$ & 40 & 0 & 2 & $<10$ & $<1$ & 1.1 & $<3$ & 190 & 10 & 0 \\
\hline G60 & BCKK & B. $1-B 0$ & 4.4 & 37 & 291 & 563 & - & $<1$ & 40 & 0 & $<2$ & $<10$ & 4 & $<.1$ & 6 & 210 & 20 & 0 \\
\hline G62 & ALVM & B.15.79 & 86 & - & 246 & 426 & 73 & $<1$ & 20 & 20 & - & $<10$ & - & - & 7 & 120 & 20 & 1 \\
\hline & & $7-24-80$ & 79 & 30 & 248 & 429 & 7.2 & 1 & 30 & 0 & $<2$ & $<10$ & $<1$ & $<1$ & 7 & 130 & 10 & 1 \\
\hline G63 & ALVM & $8 \cdot 15-79$ & - & 51 & 302 & 522 & 7.1 & $<1$ & 30 & 10 & - & 20 & - & - & 10 & 150 & 20 & 2 \\
\hline G64 & BCKK & $8-15-79$ & 81 & - & 279 & 450 & 7.3 & $<1$ & 20 & 10 & - & $<10$ & - & - & 30 & 130 & 20 & 0 \\
\hline & & $7.24-80$ & 7.4 & 17 & 272 & 469 & 7.3 & 1 & 50 & 0 & $<2$ & $<10$ & $<1$ & .3 & 10 & 130 & 10 & 0 \\
\hline G65 & $B C K K$ & $7-23-80$ & 4.1 & 42 & 271 & 464 & 7.1 & 1 & 50 & 1 & 2 & $<10$ & $<1$ & $<.1$ & 4 & 130 & 10 & 1 \\
\hline G66 & SRPN & 7.31 .79 & 8.9 & 46 & 333 & 524 & 7.5 & $<1$ & 20 & 10 & - & 840 & - & - & 50 & 160 & 20 & 0 \\
\hline & & $7 \cdot 24-80$ & 8.9 & 97 & 334 & 572 & 7.2 & 1 & 50 & 0 & $<2$ & 880 & 3 & $<.1$ & 4 & 170 & 10 & 0 \\
\hline G69 5 & BCKK & 8. $5 \cdot 80$ & 4.5 & - & 192 & 347 & 7.7 & 1 & 20 & 0 & $<2$ & $<10$ & $<1$ & $<.1$ & 6 & 60 & 6 & 0 \\
\hline G70 & SRPN & $7 \cdot 29-80$ & 5.8 & - & 295 & 523 & 7.2 & 1 & 60 & 0 & $<2$ & $<10$ & 2 & $<.1$ & 50 & 160 & 20 & 0 \\
\hline G71 & BCKK & $7 \cdot 25-80$ & 68 & 255 & 422 & 692 & 7.2 & 1 & 110 & 0 & $<2$ & 720 & 2 & $<.1$ & 10 & 190 & 10 & 0 \\
\hline G73 & CSLG & $7-24-80$ & 6.3 & 53 & 304 & 492 & 6.9 & 1 & 40 & 1 & $<2$ & 600 & $<1$ & .8 & $<3$ & 290 & 20 & 0 \\
\hline G76 & CSLG & $7.24-80$ & 6.1 & 2.3 & 282 & 479 & 7.1 & 1 & 40 & 0 & 2 & $<10$ & $<1$ & $<.1$ & $<3$ & 120 & 9 & 0 \\
\hline G89 & NRHR & $7.31-80$ & 8.7 & 4.3 & 629 & 1.110 & 7.5 & $<1$ & 170 & 0 & $<2$ & $<10$ & $<1$ & .9 & $<3$ & 960 & 20 & 0 \\
\hline G90 & FLGF & $7 \cdot 30.80$ & 8.1 & 9.2 & 356 & 669 & 7.2 & $<1$ & 70 & 0 & 3 & $<10$ & $<1$ & 1.0 & $<3$ & 360 & 10 & 1 \\
\hline G91 & FLGF & $730 \cdot 80$ & 8.5 & 10 & 324 & 572 & 7.4 & 1 & 50 & 0 & $<2$ & $<10$ & $<1$ & $<.1$ & $<3$ & 260 & 10 & 1 \\
\hline G92 & FLGF & $7 \cdot 30-80$ & 8.0 & 15 & 285 & 517 & 7.4 & 1 & 120 & 0 & $<2$ & $<10$ & 2 & $<.1$ & $<3$ & 250 & 7 & 1 \\
\hline G93 & FLGF & 7.31 .80 & 129 & 30 & 262 & 549 & B.3 & 1 & 60 & 0 & $<2$ & $<10$ & $<1$ & $<.1$ & $<3$ & 290 & 8 & 1 \\
\hline G94 & FLGF & 7.31 .80 & 6.3 & 39 & 339 & 603 & 7.3 & $<1$ & 50 & 0 & $<2$ & $<10$ & $<1$ & .6 & $<3$ & 260 & 6 & 0 \\
\hline G95 & FLGF & $7.30-80$ & 81 & 27 & 345 & 616 & 7.3 & $<1$ & 50 & 0 & $<2$ & $<10$ & $<1$ & $<.1$ & $<3$ & 350 & 9 & 1 \\
\hline G96 & CLTN & 7.30 .80 & 9.1 & 41 & 330 & 614 & 7.2 & 2 & 140 & 0 & $<2$ & 20 & 2 & $<.1$ & $<3$ & 360 & 10 & 0 \\
\hline 697 & FLGF & $730-80$ & 6.7 & 4.0 & 340 & 584 & 7.3 & $i$ & 70 & 0 & $<2$ & $<10$ & $<1$ & $<.1$ & $<3$ & 300 & 10 & 1 \\
\hline G98 5 & BCKK & 8.16 .80 & 16.5 & - & 589 & 1,260 & 7.5 & 1 & 460 & 0 & $<2$ & $<10$ & $<1$ & .2 & $<3$ & 1.100 & 140 & 0 \\
\hline $\mathrm{G} 100$ & BCKK & 7.28 .80 & 8.5 & 66 & 651 & 1,020 & 7.2 & 1 & 150 & 1 & 3 & 200 & 2 & 1.1 & 5 & 480 & 30 & 0 \\
\hline G110 & BCKK & 8. $5 \cdot 80$ & 100 & - & 462 & 770 & 7.4 & $<1$ & 60 & 0 & $<2$ & $<10$ & $<1$ & $<.1$ & $<3$ & 370 & 10 & 0 \\
\hline G1 104 & BCKK & 8. $5 \cdot 80$ & 128 & - & 752 & 1,170 & 7.5 & 1 & 150 & 0 & $<2$ & $<10$ & $<1$ & $<.1$ & $<3$ & 1.100 & 30 & 0 \\
\hline G1106 & BCKK & 8. $5 \cdot 80$ & 128 & - & 917 & 1,420 & 7.3 & 1 & 90 & 0 & $<2$ & $<10$ & $<1$ & $<.1$ & 7 & 790 & 20 & 0 \\
\hline G111 & BCKK & 8. $5-80$ & 80 & - & 485 & 832 & 7.2 & 1 & 30 & 0 & $<2$ & 280 & $<1$ & $<.1$ & $<3$ & 220 & 20 & 0 \\
\hline G114 & BCKK & 8. $5-80$ & 10.2 & - & 2,160 & 2,790 & 76 & $<1$ & 430 & 0 & $<2$ & 20 & $<1$ & $<.1$ & 10 & 3,600 & BO & 0 \\
\hline G115 & BCKK & 8. 5.80 & 109 & - & 3,300 & 4,290 & 8.0 & 1 & 1,200 & 0 & $<2$ & 20 & $<1$ & $<1$ & 10 & 2,000 & 140 & 0 \\
\hline
\end{tabular}

1 Spring issues trom soll developed on Blackhawk Formation 
tium generally parallels that of the concentration of dissolved solids, with the largest concentrations occurring in water discharging from the Blackhawk Formation in the Book Cliffs (plate 1).

\section{HYDROLOGY OF THE MUD CREEK DRAINAGE BASIN}

\section{Precipitation and Streamflow}

The normal annual precipitation in the Mud Creek drainage during 1931-60 varied from less than 25 to more than 30 inches (fig. 1) and averaged 28 inches. Precipitations was measured at sites CO.3 and CO.4 during the 1980 water year, and comparison of the measured values with the 1931-60 values indicated that precipitation during the 1980 water year was about 7 percent greater than normal at site $\mathrm{CO} .3$ and about 20 percent greater than normal at site CO.4.

Streamflow was gaged at the mouth of Eccles Canyon (site S29) during the 1980 water year and near the mouth of Mud Creek (site S36) during the 1978-80 water years. During the 1980 water year, the discharge from Eccles Canyon was 2,920 acre-feet and at the gage in Mud Creek it was 13,470 acre-feet (U.S. Geological Survey, 1980, p. 227 and 233). The discharge during the 1980 water year at a long-term station on Fish Creek (site S2) was about 80 percent greater than its long-term average (U.S. Geological Survey 1980, p. 226). Because the drainage of Mud Creek is adjacent to Fish Creek, the streamflow during the 1980 water year in Mud Creek also probably was about 80 percent greater than average.

\section{Ground Water}

Water Levels

Water levels were measured at only a few wells in the Mud Creek drainage. Although numerous test holes have been drilled, few were constructed so that differences in water level with depth could be determined. For example. Coastal States Energy Co. drilled nine holes in 1979 (Vaughn Hansen Associates, written commun., 1980). The depths of the holes ranged from about 150 to 1,710 feet, with most exceeding 1,000 feet. All the holes penetrated the Star Point Sandstone and the Blackhawk Formation and were open from surface to bottom. Thus, the static water levels in the holes represent a composite of the hydraulic heads in the two formations.

The most definitive water-level data were obtained from well G60.7 (fig. 15), which was drilled to a depth of 1,260 feet. The upper 310 feet was open to the Blackhawk Formation, and from depths of 310 to 1,260 feet the hole was open to the Star Point Sandstone. Water-level measurements were made during drilling when the hole was at various depths. The lower O'Connor A coal seam was penetrated at depths from 145 to 150 feet, and a water level of 82 feet below land surface was measured when the depth of the hole was 250 feet. Thus, the water level was about 63 feet above the O'Connor A coal seam.

As the well was deepened from 250 to 850 feet, the depth to water increased. For depths between 825 and 1,260 feet, the static water levels ranged from 220 to 243 feet below land surface. The decreasing hydraulic head with increasing depth indicates that water was moving downward from the Blackhawk Formation and recharging the underlying Star Point Sandstone.

The available data indicate that the coal-bearing zones in the Blackhawk Formation probably are saturated in most areas and will require dewatering during mining. Exceptions to this are along canyons where the coal-bearing zones may be drained.

During 1980, Coastal States Energy Co. drilled three test wells (G60.8, G60.9, G66.5, fig. 15), and Valley Camp Coal Co. drilled a production well (G66.7, fig. 15). Although these wells range in depth from 135 to 1,055 feet, they are open only to the Star Point Sandstone. Contours depicting the altitude of the potentiometric surface in the Star Point were drawn from water levels measured in the four wells and in well G60.7 (fig. 15). The contours indicate that the direction of ground-water movement in the Star Point approximately parallels the surface drainage. In Eccles Canyon, upstream from well G60.9, the gradient of the potentiometric surface is about 100 feet per mile; downstream from well G60.9, the gradient is about 300 feet per mile. The change in gradient may be due to the north-trending fault that crosses Eccles Canyon near well G60.9.

The water level in the Star Point Sandstone ranges from about 15 to 243 feet below the land surface between wells $G 60.7$ and $G 60.9$, but at wells $G 60.9$ and G66.5, the water level is near the streambed of Eccles Canyon. Seepage studies made from site G60.9 to the mouth of Eccles Canyon indicate that water is discharged from the Star Point to the stream.

\section{Discharge to Streams}

The discharge areas in the Mud Creek drainage basin were determined by measuring the base flow at sites along Mud Creek and Eccles Canyon during 1979-80 and by measuring the discharge of springs. During the 1980 water year, the estimated discharge from the major mines and springs issuing from the Blackhawk Formation and Star Point Sandstone was 1,340 acre-feet.

The streamflow at sites along Mud Creek and Eccles Canyon is shown in figures 16 and 17. The gains from point sources of inflow from mines, springs, and 


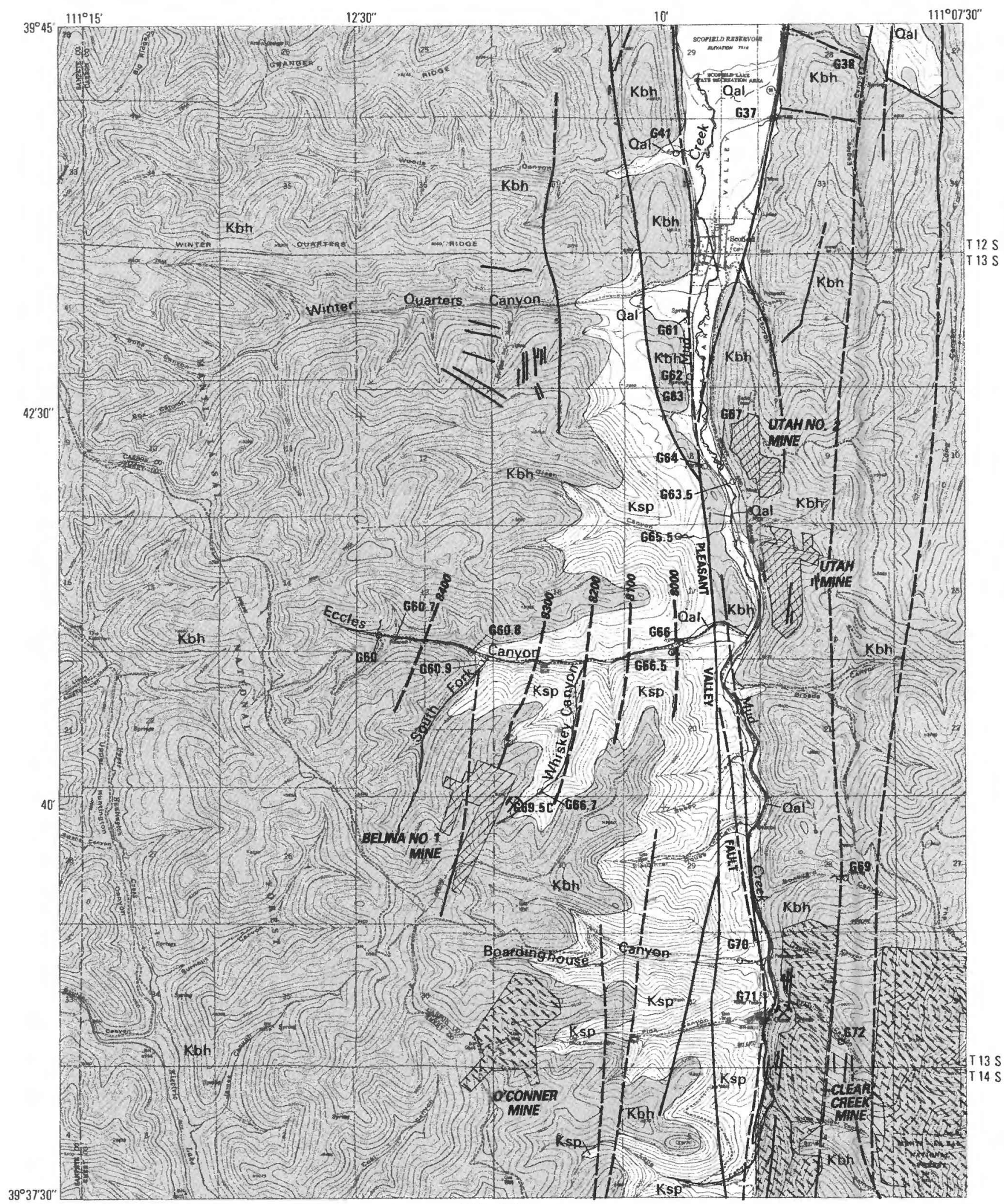

Base from U.S. Geological Survey Scofield, 1:24,000, 1979

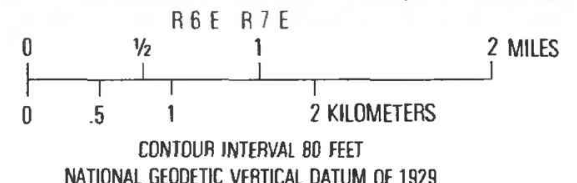

Geology from Spieker, 1931 (Plate 31) 


\section{EXPLANATION}

\section{Qal}

$\mathrm{Kbh}$

Ksp

STAR POINT SANDSTONE (CRETACEOUS)

CONTACT

FAULT-Dashed where approximately located

ACTIVE COAL MINE

INACTIVE COAL MINE

HYDROLOGICAL DATA SITE AND NUMBER

$\begin{array}{cl}0^{641} & \text { SPRING } \\ \delta^{666.7} & \text { WELL } \\ x^{\mathbf{6 6 9 . 5}} & \text { MINE PORTAL }\end{array}$

APPROXIMATE POTENTIOMETRIC CONTOUR-ShOWS approximate altitude at which water would have stood in tightly cased wells completed in the Star Point Sandstone. Contour interval 100 feet. National Geodetic Vertical Datum of 1929

Figure 15. (above and facing page) Geology, data-collection sites for ground water, and potentiometric surface for the Star Point Sandstone in the Mud Creek drainage basin, 1980.

tributaries are indicated by the abrupt rise in the graph at the point of inflow. Seepage gains or losses are indicated by the rise or fall of the graph between measuring sites. Streamflow at all sites in Eccles Canyon and on Mud Creek was greater during September 1980 than during October 1979, but downstream trends generally were similiar.

During periods of low flow, water in Mud Creek is derived principally from Boardinghouse. Eccles and Winter Quarters Canyons, from an abandoned mine, and from seepage from the Star Point Sandstone and Blackhawk Formation. The loss of streamflow between sites S5 and S8 is believed to be due to seepage into abandoned tunnels of the Clear Creek Mine (fig. 2), which underlies parts of Mud Creek between sites S5 and S8. Between sites S8 and S11, however, discharge from the mine entered the stream. Discharge from the mine was 130 gallons per minute on October 12, 1979, and 265 gallons per minute on September 5, 1980. This contrasts with stream discharges immediately upstream from the mine at site S5 and S8 of about 18 gallons per minute or 0.04 cubic feet per second and 175 gallons per minute or 0.39 cubic feet per second, respectively.

Directly downstream from site S11, inflow from Boardinghouse Canyon also causes an increase of streamflow. Most of the inflow from Boardinghouse Canyon is contributed from Boardinghouse Spring (site G70, fig. 15), which is a large seepage area issuing from the
Star Point Sandstone along the Pleasant Valley fault zone near the mouth of Boardinghouse Canyon. The discharge of the spring during October 1979 was 180 gallons per minute and during September 1980 it was 350 gallons per minute. Between sites S16 and S19, Mud Creek gained approximately 180 gallons per minute on October 13, 1979, and September 5, 1980. These gains represent discharge from the Star Point Sandstone along the Pleasant Valley fault.

Downstream from Eccles Canyon, measured gains and losses in streamflow were inconsistent in 1979 and 1980. The inconsistency may be due to measurement errors or to changes of storage in the alluvium. Although the thickness of the alluvial deposits is not known, the areal extent increases downstream from the mouth of Eccles Canyon (fig. 15). A 5- to 10-percent error is not uncommon for measurements made with pygmy current meters and for a discharge of 2,000 gallons per minute or 4.5 cubic feet per second, the error could be as much as 200 gallons per minute or 0.45 cubic feet per second.

The base flow of the stream in Eccles Canyon is derived principally from South Fork and seepage from the Star Point Sandstone. The largest and most consistent increase of flow in Eccles Canyon was in the reach between the inflow of South Fork and site S26.5, On October 12, 1979, the gain was 190 gallons per minute, and on September 5, 1980, it was 230 gallons per minute. The Star Point Sandstone is exposed in Eccles Canyon from near site S24 to almost the mouth of the canyon. The potentiometric surface in the Star Point Sandstone intercepts the floor of Eccles Canyon near the contact with the underlying Blackhawk Formation (fig. 17). A northtrending fault, which crosses Eccles Canyon at the junction with South Fork Canyon, may be the major source area for the gains between South Fork and site S26.5.

Whiskey Canyon, which conveys water discharged from the Belina No. 1 Mine, also contributes considerable quantities of inflow to Eccles Canyon; but the volume of mine discharge, as opposed to natural discharge, was not determined. On September 5, 1980, a gain of about 130 gallons per minute was measured between Whiskey Canyon and site S28.

Between sites S28 and S30, gains of about 200 gallons per minute were measured on September 5, 1980. Changes on October 12,1979, could not be determined accurately because of unsteady flow from Whiskey Canyon. The increase in flow on September 5, 1980, was caused by seepage from a large area along the Pleasant Valley fault zone (fig. 18). Within an area about 500 feet upstream from site S30, the water level in a well in the Star Point Sandstone is within 2 to 3 feet of the land surface. There is considerable diffuse seepage, and spring G66 (Iron Spring) discharged 45 to 84 gallons per minute on October 11. 1979, and September 5, 1980. 

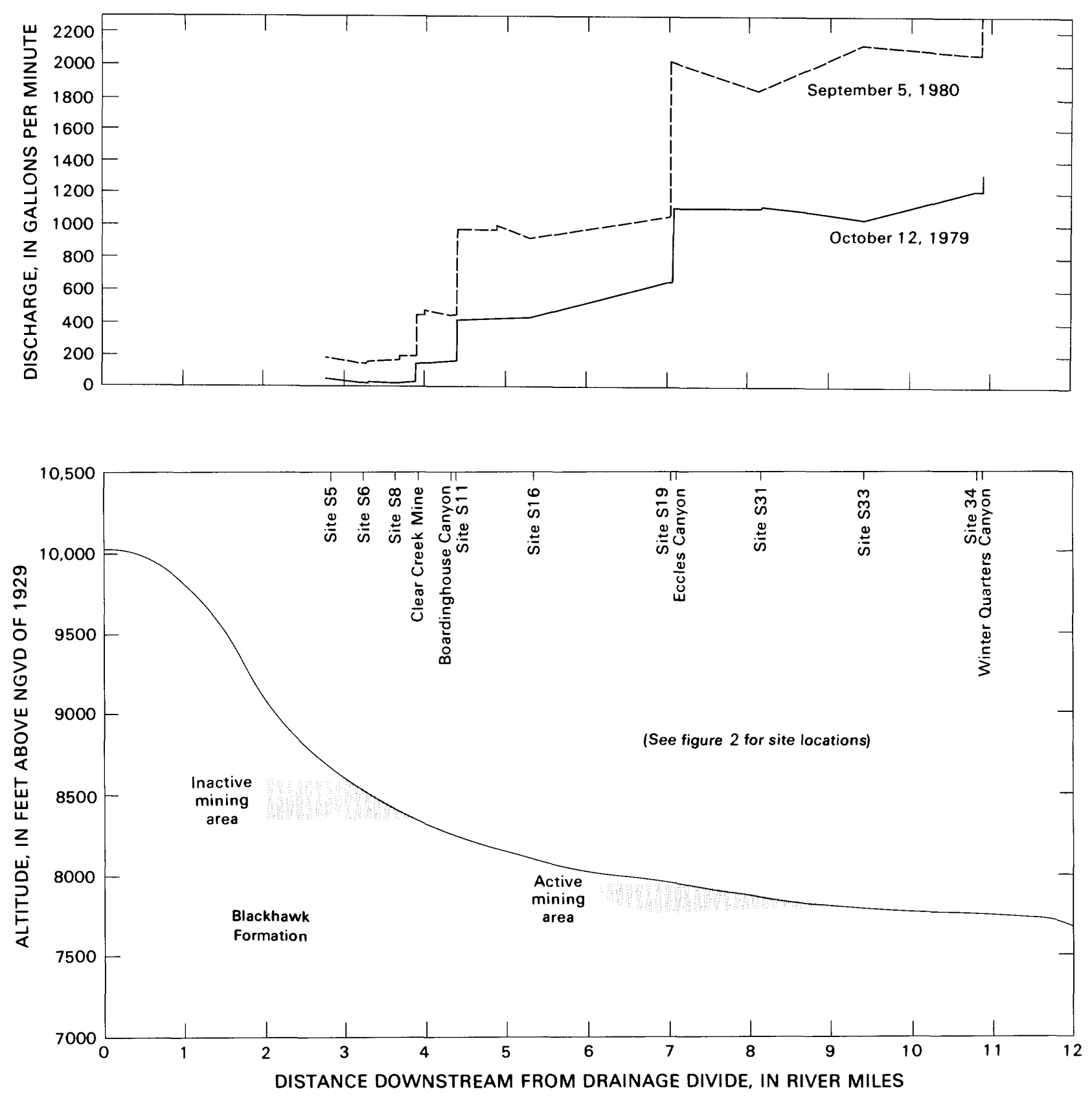

Figure 16. Profile of Mud Creek and streamflow hydrographs for October 12, 1979, and September 5, 1980

\section{HYDROLOGY OF THE SOLDIER CREEK AREA}

\section{Precipitation and Streamflow}

The normal annual precipitation in the Soldier Creek area during 1931-60 ranged from about 12 to 16 inches (fig. 1). During 1980, at a National Oceanic Atmospheric Administration measuring site at Sunnyside, precipitation was about 40 percent greater than average. Based on this percentage, precipitation in the Soldier Creek area probably ranged from 17 to 22 inches during 1980 .
Table 10. Estimated ground-water and surface runoff from Coal, Soldier, and Dugout Creeks during the 1980 water year. Site No.: See figure 1 for location. Runoff values are in acre-feet.

\begin{tabular}{|c|c|c|c|c|c|}
\hline \multirow[b]{2}{*}{ Site No. } & \multirow[b]{2}{*}{ Stream } & \multicolumn{2}{|c|}{ Ground-water runoff } & \multirow[b]{2}{*}{$\begin{array}{l}\text { Surface } \\
\text { runoff }\end{array}$} & \multirow[b]{2}{*}{$\begin{array}{l}\text { Total } \\
\text { runoff }\end{array}$} \\
\hline & & Flagstaff Limestone & $\begin{array}{l}\text { Blackhawk and } \\
\text { other formations }\end{array}$ & & \\
\hline$\$ 377$ & Coal Creek & 1,600 & 1,000 & 2,000 & 4,600 \\
\hline S59 & Soldier Creek & 1,800 & 1.000 & 1,400 & 4.200 \\
\hline \multirow[t]{2}{*}{$\$ 60$} & Dugout Creek & 1,000 & 200 & 700 & 1,900 \\
\hline & Total & 4,400 & 2,200 & 4,100 & 10,700 \\
\hline
\end{tabular}



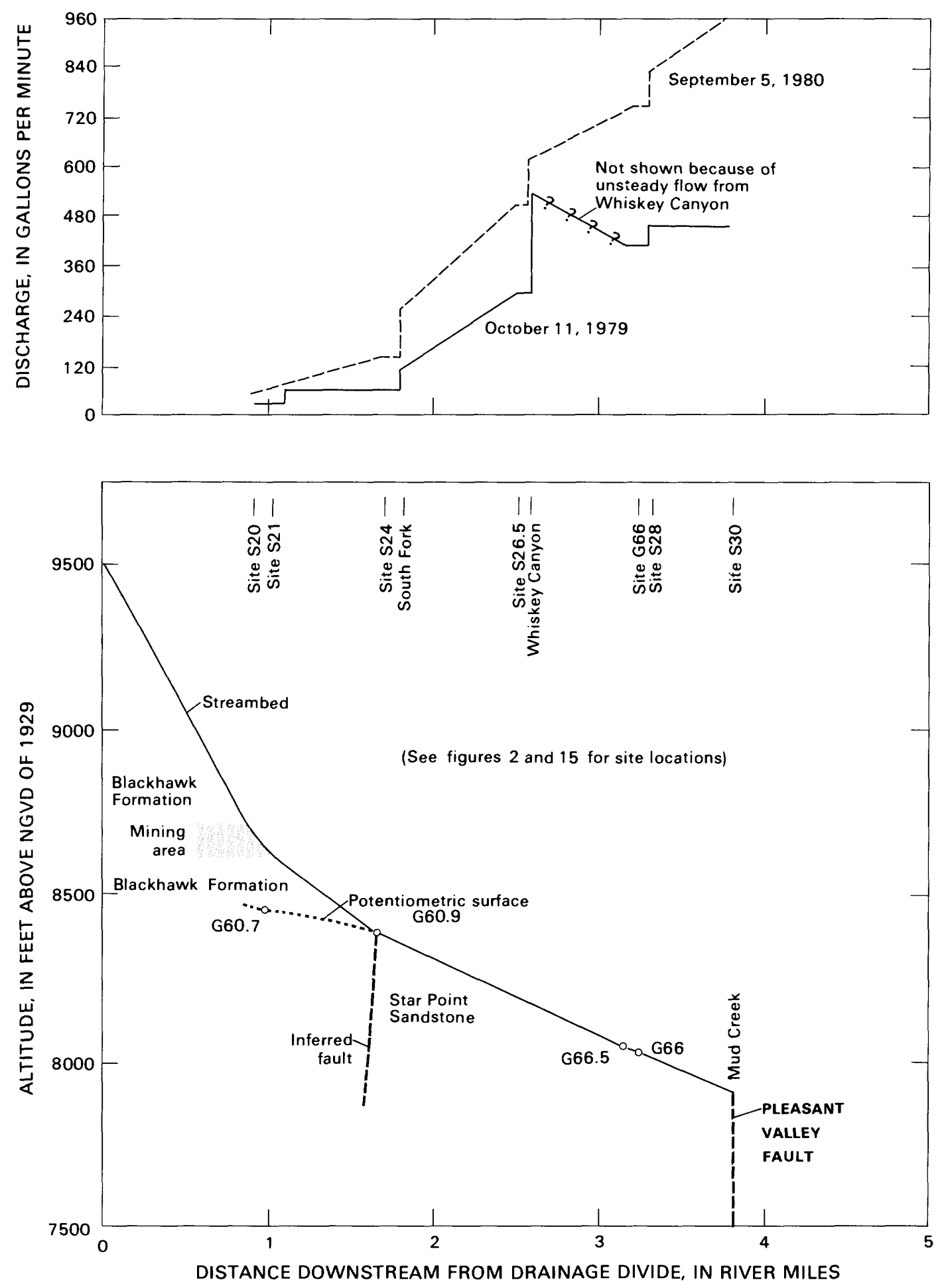

Figure 17. Profile of Eccles Canyon and hydrographs of streamflow on October 11, 1979, and September 5, 1980.

Streamflow in the Soldier Creek area was monitored seasonally by the U.S. Geological Survey at gaging stations on Coal, Soldier, and Dugout Creeks during the 1979-80 water years. The partial records of streamflow at these sites were used to estimate annual runoff from each stream during the 1980 water year (table 10). Streamflow during the 1980 water year probably was greater than average because of the greater than average 

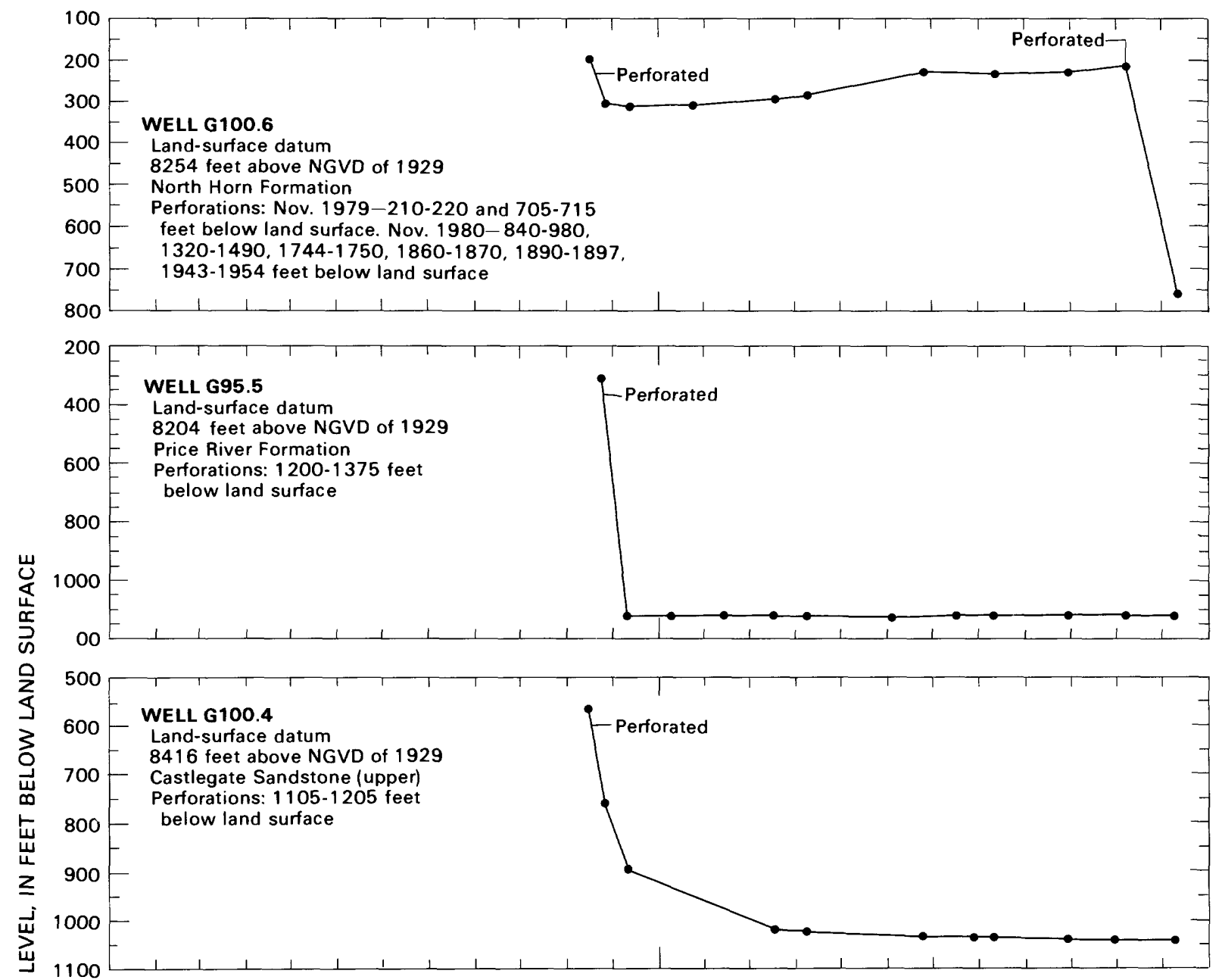

$\stackrel{\frac{a}{4}}{\frac{5}{5}}$
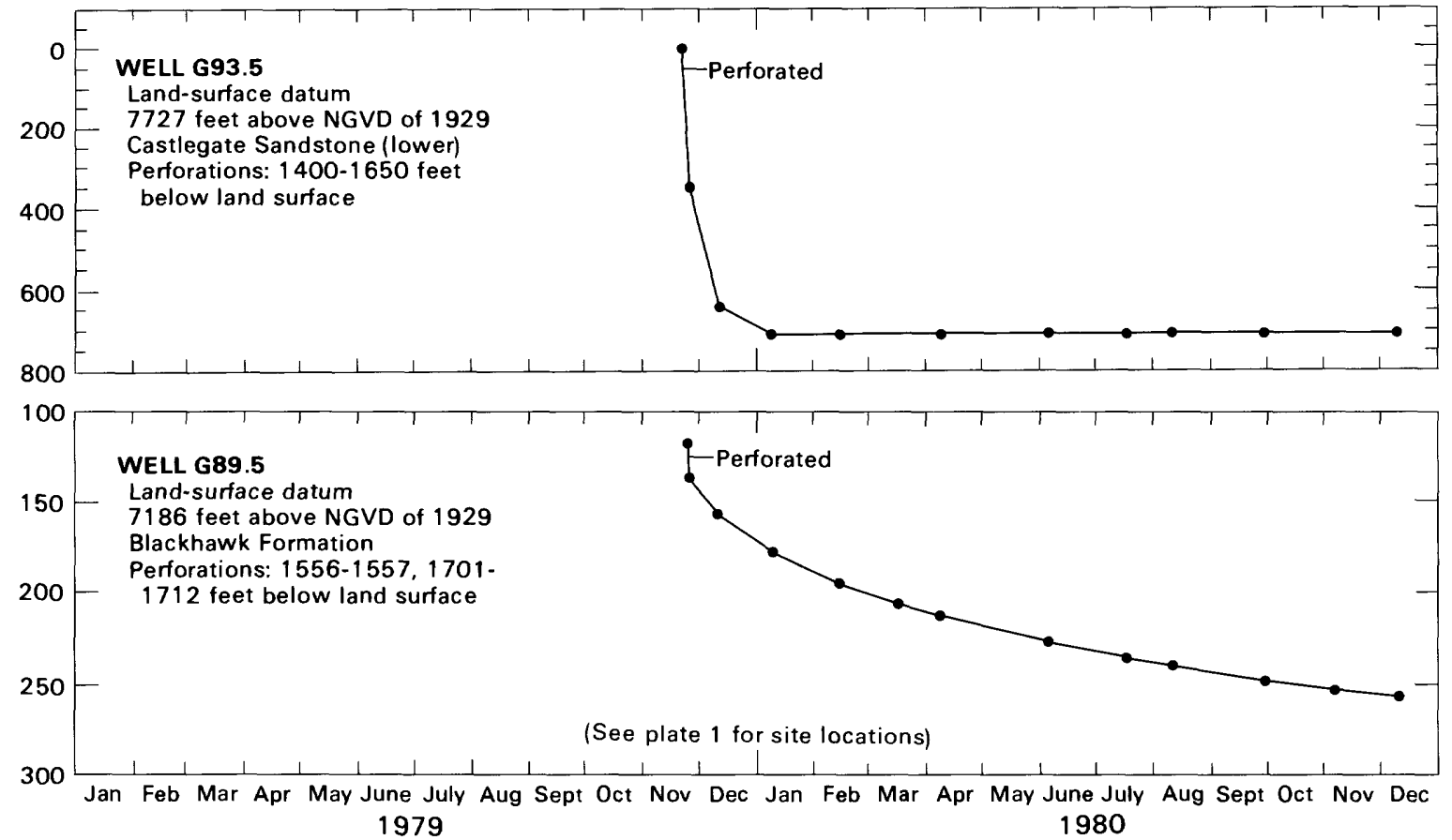

Figure 18. Decline of fluid level after perforating the casings of five wells in the Soldier Creek area. 
precipitation. For example, the discharge of Willow Creek during the 1980 water year at site S37.3 (fig. 1) was about 96 percent greater than the average discharge for the 1971-80 water years.

\section{Ground Water}

\section{Hydraulic Properties of the Ground-Water Reservoir}

During 1978-79, Eureka Energy Co. drilled five test wells in the Soldier Creek area (plate 1). Each test well penetrated the Gilson, Rock Canyon, and Sunnyside coal seams in the Blackhawk Formation. The test wells were cased and cemented to seal the annular space between the casing and the formation, and then the casing was perforated in selected zones of a single formation. Test well G100.6 was perforated in the North Horn Formation, G95.5 in the Price River Formation, G93.5 in the upper part of the Castlegate Sandstone, G100.4 in the lower part of the Castlegate Sandstone, and G89.5 in the three coal zones in the Blackhawk. Prior to perforating the well casings, each of the test wells was partly filled with residual drilling fluids, and the fluid level was several hundred feet above the static water level that eventually was determined for each zone.

In three of the test wells, transmissivity was estimated by measurements of water-level changes (fig. 18). The water-level data were analyzed in a manner similar to that for a "slug test" (Cooper and others, 1967), wherein a given volume of water is either added to or withdrawn from the well and the change in water level is measured within a specified time. In this instance, the water was in the test wells, but the time of perforating marked the beginning of the test. The computed transmissivities need to be used with considerable discretion because the perforated zones only partly penetrated the formations being tested, and the tests at some wells had durations of several months. Thus, there may have been vertical leakage into the formation overlying the one being tested. For the tests to be valid, it was assumed that the aquifer was reasonably homogeneous and isotropic in planes parallel to the beddings (Cooper and others, 1967, p. 269).

The transmissivity was computed by means of the type curves presented by Cooper and others (1967, fig. 3, p. 267). As the storage coefficient was unknown, the type curve that best fit the test data was used-the type curve with a storage coefficient of 0.00001 . Estimated transmissivities for the test wells were:

\begin{tabular}{llr}
\hline Test hole & \multicolumn{1}{c}{ Geologic unit } & $\begin{array}{c}\text { Transmissivity } \\
\text { (foot squared per day) }\end{array}$ \\
\hline G 95.5 & Price River Formation & 0.07 \\
G 93.5 & $\begin{array}{l}\text { Upper part of the Castlegate } \\
\text { S100.4 }\end{array}$ & .02 \\
Lowdstone & Lower part of the Castlegate \\
Sandstone & .003 \\
\hline
\end{tabular}

\section{Water Levels}

The altitudes of water levels in six wells and an abandoned mine portal are shown in figure 19. The distribution of hydraulic head with depth is not known at any of the wells. However, at well G100.6, which was initially perforated only in the North Horn Formation, additional perforations opened the well to the Price River Formation, the Castlegate Sandstone, and coalbearing zones in the Blackhawk Formation. After the second round of perforations, the water level declined about 540 feet. This indicated that the head in the North Horn was several hundred feet greater than the composite head of the underlying formations.

Water-level data for three sites in the Blackhawk Formation indicate that the potentiometric surface slopes northward away from the face of the Book Cliffs. The altitude of the potentiometric surface at site G99.7, a mine portal at the face of the cliffs, was 7,035 feet above sea level. At well G89.5, about 1.4 miles into the cliffs, the potentiometric surface was 6,938 feet above sea level; and at well G58.5, about 3.2 miles into the cliffs, it was 6,896 feet above sea level. This represents an average gradient of about 42 feet per mile.

The available data indicate that the coal-bearing zones in the Blackhawk Formation probably are saturated in most areas and will require dewatering during mining. Exceptions to this are along canyons where the coalbearing zones may be drained.

The Flagstaff Limestone contains a perched aquifer in the Soldier Creek area. This is indicated by the occurrence of a large number of springs that issue from the Flagstaff near the contact with the underlying North Horn Formation at altitudes several hundred feet above water levels in wells that are completed in underlying formations. An aquifer perched in the Flagstaff would be hydraulically separated from aquifers in the Balckhawk formation and thus would not be affected by dewatering of the coal-bearing zones. Subsidence, however, could 


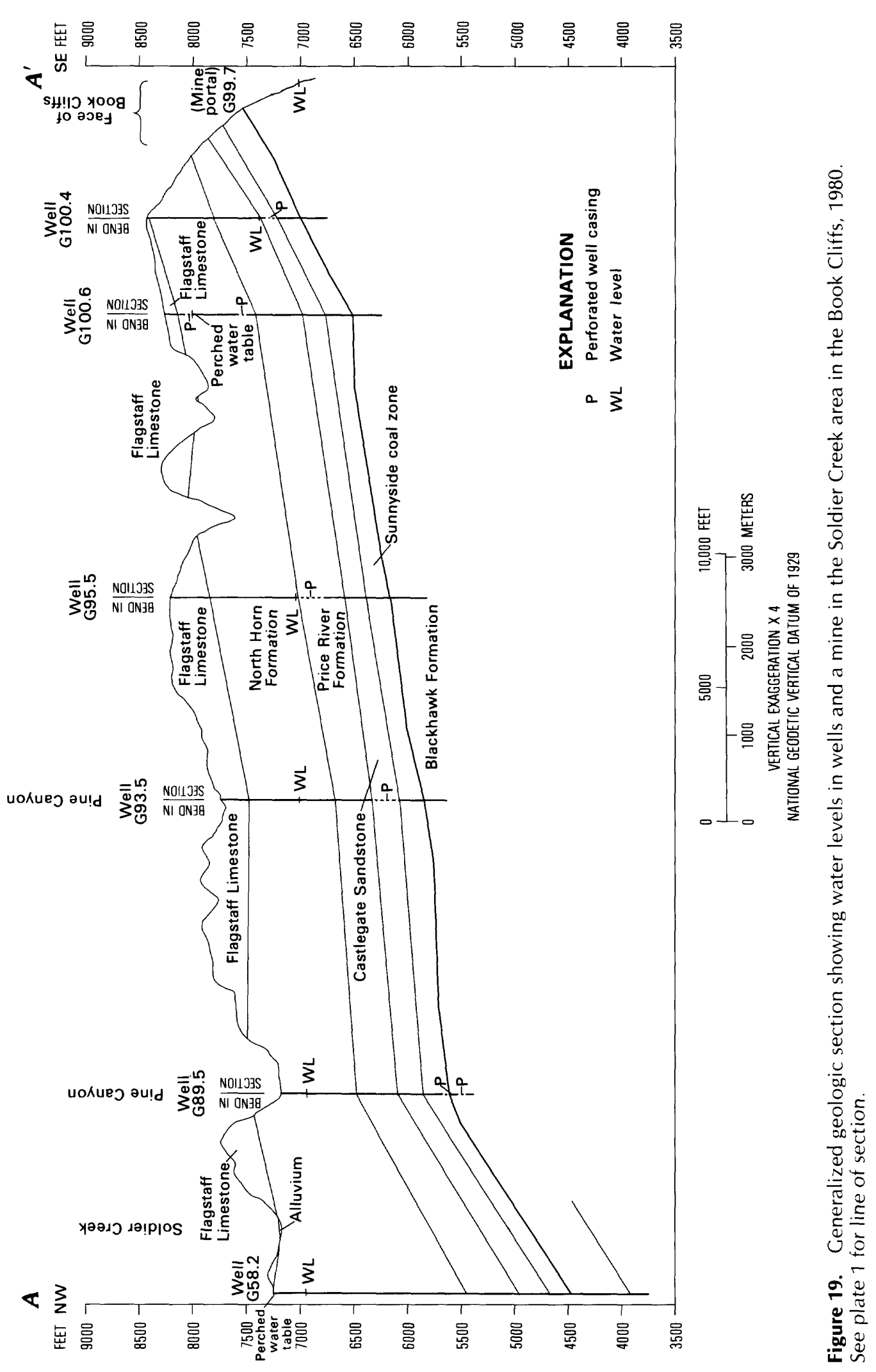


create extensive fractures that would allow water from the Flagstaff to move down to the Blackhawk.

\section{Recharge to the Flagstaff Limestone}

Recharge to the Flagstaff Limestone in the Soldier Creek area was computed by measuring the discharge of springs that drained a selected outcrop area (plate 1) and assuming that recharge equals discharge. The springs used for computation of discharge are listed in table 11 . All the springs are either above or within 100 feet of the base of the Flagstaff.

The flow of Soldier and Dugout Creeks began to respond to snowmelt during the latter part of April and peaked during May 1980. Thus, the recharge period probably began during the latter part of April. The flow of the springs was difficult to distinguish from overland flow during the snowmelt period. Thus, it was necessary to estimate the flow of the springs during the latter part of April and during May.

The flow of springs G92 and G94 was measured during the first week of April, prior to the beginning of snowmelt. The discharges were slightly less than measured during the prior fall, indicating that they had not been affected by recent recharge. The snowpack was almost melted near the end of May, and frequent monitoring of all the springs began during the first week of June and continued through September. The largest flows measured for all springs was at the time of the first measurement in June. Thus, the peak flows may have occurred prior to the first set of measurements.

The total discharge from the Flagstaff Limestone as measured at the eight springs plus seepage gain in Pine Canyon was 670 acre-feet. Distributed over the outcrop area of 4,020 acres, this is equivalent to a recharge of 2 inches per year.

The recharge of 2 inches per year can be expressed as a percentage of the April 1 snowpack. The water content of the snowpack on the recharge area was computed using data collected by Eureka Energy Co. during March and April 1980 at two snow courses in Pine Canyon. The average water content for March and April ranged from 15 inches at the snow course in lower Pine Canyon to 19 inches at the course in upper Pine Canyon. It was assumed then that the average water content over the recharge area was 17 inches. Thus, the recharge was about 12 percent of the April 1 snowpack.

The recharge of 2 inches per year also can be expressed as a percentage of the average annual precipitation. Normal annual precipitation during 1931-60 for the recharge area was estimated to be 16 inches (fig. 1). Through use of the precipitation data at Sunnyside, Utah, the adjusted precipitation for 1980 was estimated
Table 11. Discharge of water from springs and seepage gains in Pine Canyon used to estimate recharge to the Flagstaff Limestone, 1980 water year

Site No.: See plate 1 for location.

\begin{tabular}{|c|c|c|c|}
\hline Site No. & Period of measurement & Period of estimation & Discharge \\
\hline G88 & $520-80$ to $7-3180$ & $11-79$ to $5-80$ & 35 \\
\hline G90 & $10-11-79$ to $8-2080$ & $11-79$ to $5-80$ & 497 \\
\hline G91 & 1011.79 to $9-1980$ & 1179 to 5.80 & 421 \\
\hline G92 & $10-1179$ to $919-80$ & $11-79$ to 380 & 460 \\
\hline G93 & 6. $5-80$ to 91980 & $10-79$ to $5-80$ & 1031 \\
\hline G94 & $10-1079$ to $918-80$ & 1179 to $5-80$ & 954 \\
\hline G95 & $10-11.79$ to $9-1880$ & 1179 to $5-80$ & 118.0 \\
\hline G98 1 & 6. 80 to $9 \quad-80$ & 10.79 to $5-80$ & 593 \\
\hline \multirow[t]{2}{*}{ Pine Canyon ${ }^{1}$} & $10-1079, \quad 9 \quad 4.80$ & 11.79 to 880 & 1503 \\
\hline & & Total & 670 \\
\hline
\end{tabular}

${ }^{1}$ Represents seepage gains between sites S47 and S48

to be 22 inches. Thus, the recharge was about 9 percent of the annual precipitation.

The assumption that recharge equals discharge may not be fully valid because of the following factors: (1) Some water may have percolated into underlying aquifers; (2) some springs or seepage areas may not have been measured; (3) the gain of flow in Pine Creek (fig. 20 ) at the contact of the Flagstaff and North Horn was measured during the fall but not during the summer: (4) frequent monitoring of flows of springs did not commence until the first week of June, and the record for late April and May was estimated.

\section{Discharge to Streams}

The natural discharge areas in the Soldier Creek area were determined by measuring the base flow in Soldier and Pine Creeks during October 1979 and September 1980 (figs. 20 and 21). Although the quantities of flow were different during the two periods of measurement, most of the gaining and losing reaches were consistent.

Along Pine Creek, large gains of flow were consistently measured between sites S46 and S48 (fig. 20). In this reach, seepage into Pine Creek from the alluvium is evident near the contact of the North Horn Formation and Flagstaff Limestone. That contact also is marked by springs throughout the Soldier Creek area. Downward percolation from the Flagstaff, which has large hydraulic diffusivity, is impeded by the claystones or mudstones in the North Horn Formation, and the water then moves horizontally to emerge at the outcrop of the contact.

Most of the gains in Soldier Creek were measured where the stream crosses the North Horn Formation, upstream from site S54. A considerable part of the gain was from spring G89, which discharges just downstream 

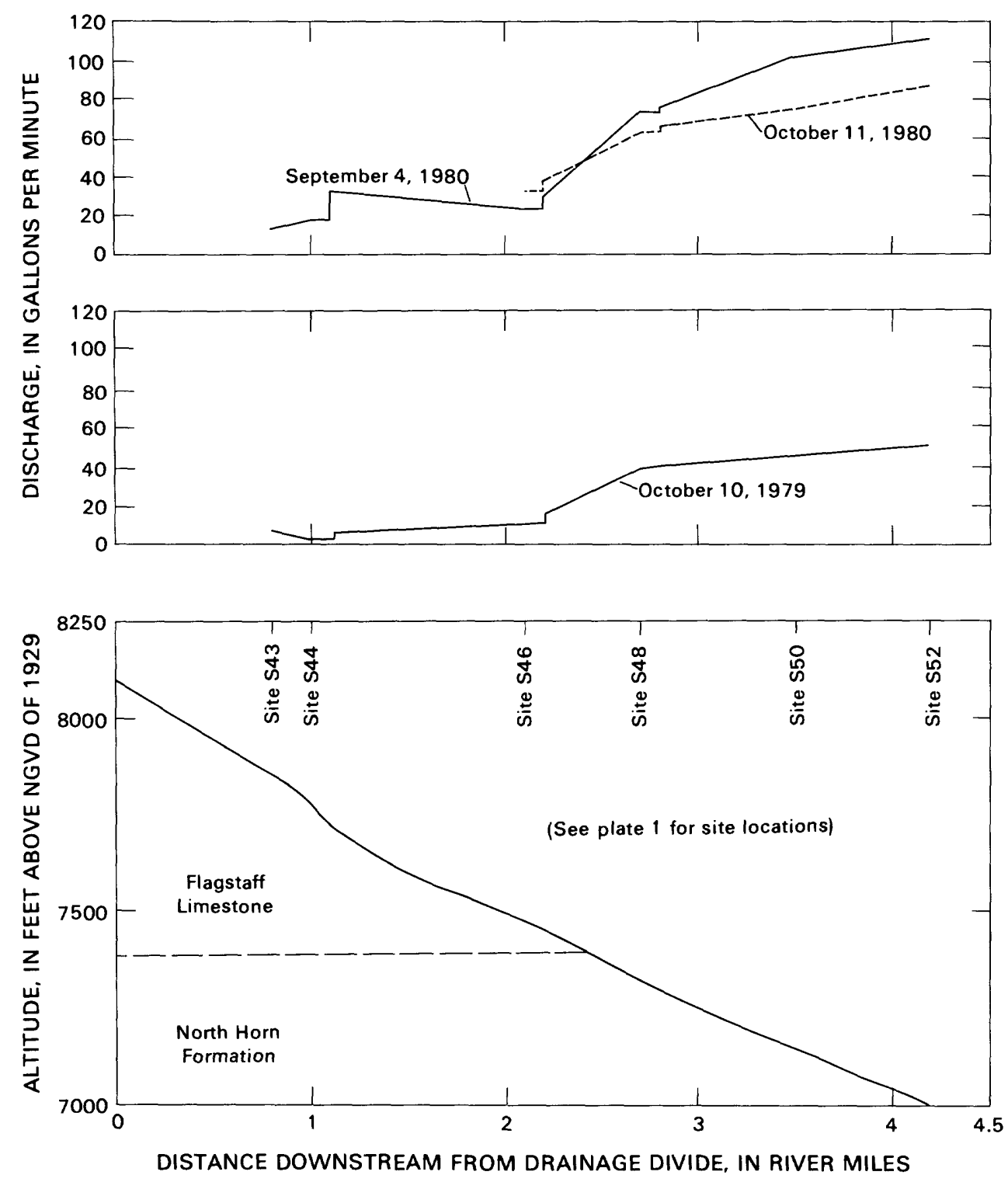

Figure 20. Profile of Pine Canyon and changes in streamflow on October 10, 1979, September 4, 1980, and October 11, 1980.

from site S42. The stream loses water where it crosses the outcrop of the Price River Formation and the Castlegate Sandstone between sites S54 and S56, but it gains where the stream crosses the outcrop of the Blackhawk Formation between sites S56 and S59.

The water that discharges from the North Horn Formation probably is moving upward from the underlying formations. Evidence for upward movement of water is: (1) The water level in well G89.5, which is perforated in the Blackhawk Formation, is at about 6,950 feet (fig. 19) above sea level and is within the range of altitudes of the gaining reach of Soldier Creek, which ranges from 6,900 to 7,000 feet above sea level; (2) the water from spring G89 has a small calcium concentration, is of the sodium bicarbonate type, and has a distinct odor of hydrogen sulfide. As discussed in the section on "Geochemical relationships," if water of this chemical character is resulting from sulfate reduction, then the most likely source would be upward movement from the Blackhawk Formation.

The sources of the ground-water component of the flow in Soldier Creek at gaging station S59 (fig. 1) were estimated from a mass balance of ions or constituents in water from several springs and creeks. The gaging station is downstream from an active coal mine near the base of the Blackhawk Formation at the mouth of Soldier Creek Canyon.

A mass balance of ions or constituents from the mixture of two waters of different chemical composition can provide satisfactory estimates of water discharge if 

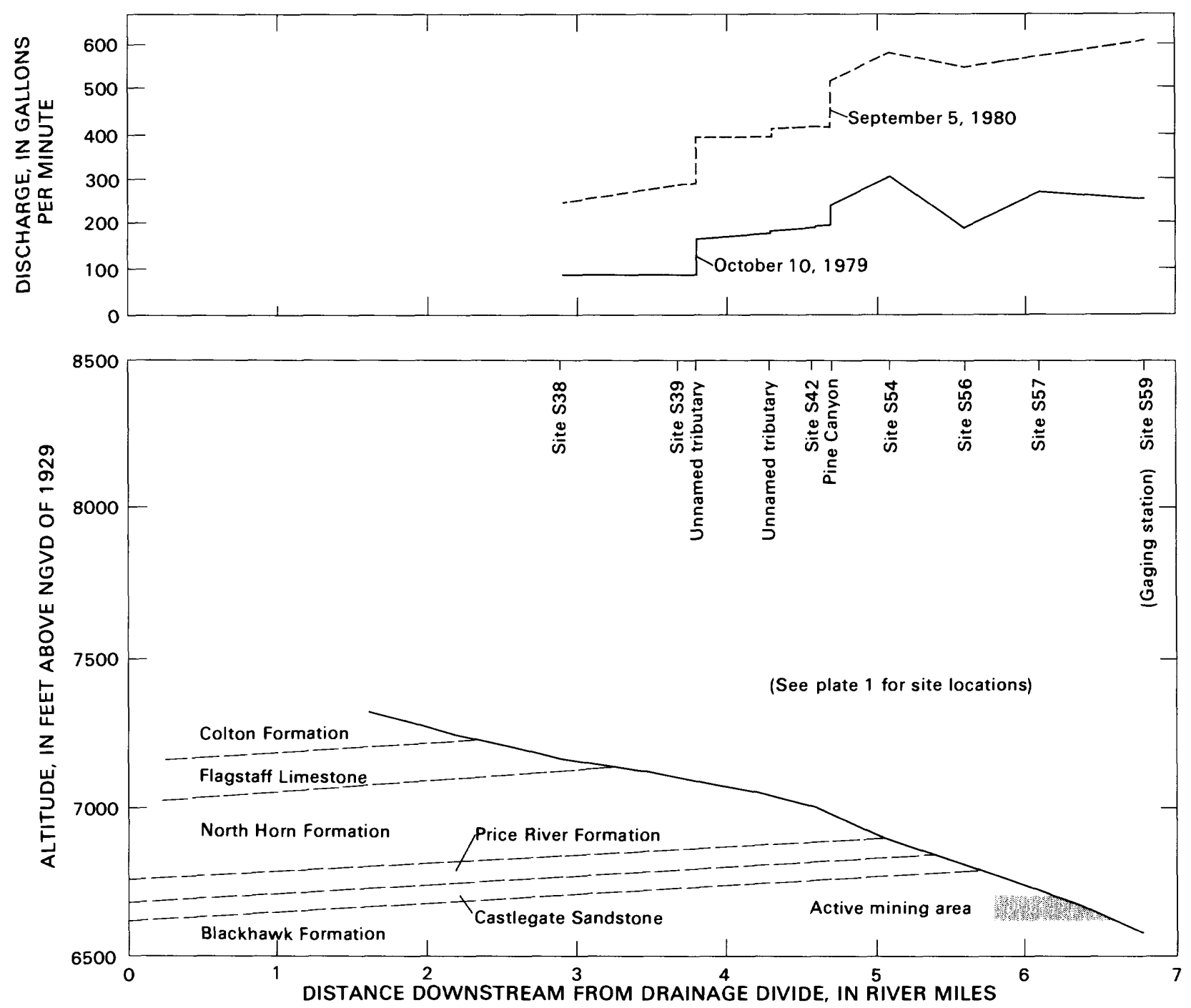

Figure 21. Profile of Soldier Creek and changes in streamflow on October 10, 1979, and September 5, 1980.

there is no chemical change in the mixed water and if the chemical composition of the two sources can be defined. The relationship between water from two sources and the resulting mixture is given by:

where

$$
C_{F} Q_{F}+C_{B} Q_{B}=C_{G} Q_{G}
$$

$C_{F}=$ concentration of ion or constituent in water from the Flagstaff Limestone;

$Q_{F}=$ discharge of water from the Flagstaff Limestone that reaches the gaging station;

$C_{B}=$ concentration of ion or constituent in the discharge of water from the Blackhawk Formation, Castlegate Sandstone, and Price River and North Horn Formations, excluding the Flagstaff Limestone;

$Q_{B}=$ discharge of water from the Blackhawk Formation, Castlegate Sandstone, and Price River and North Horn Formations, excluding the
Flagstaff Limestone, that reaches the gaging station:

$C_{G}=$ concentration of ion or constituent in water at the gaging station; and

$Q_{G}=$ discharge of water at the gaging station.

Because

$$
Q_{B}=Q_{G}-Q_{F}
$$

$Q_{B}$ can be eliminated from equation 2 and we have:

$$
Q_{F}=\frac{Q_{G}\left(C_{G}-C_{B}\right)}{\left(C_{F}-C_{B}\right)}
$$

Values of $C_{F}$ were determined from the average concentration of ions or constituents in water from springs sampled in the Soldier Creek area; whereas values of $C_{B}$ were determined from chemical analyses of samples collected during base flow at Coal, Soldier, and Dugout Creeks. 
The concentrations of sodium and sulfate ions were used in equation 4 to estimate $Q_{F}$. The sodium and sulfate ions are extremely soluble, and they are less likely to precipitate from solution in waters such as those occurring in the Soldier Creek area than are the calcium ions and carbonate. This is supported by evidence of deposition of calcium carbonate along Soldier Creek upstream from gaging station S59.

Average values for $Q_{F}$ and $Q_{B}$ were determined from two independent computations, using the concentrations of sodium and sulfate ions. As a check, the computations also were made using the concentration of dissolved solids, and the values were found to agree reasonably well with the values computed using sodium and sulfate.

For the computations of $Q_{F}$ and $Q_{B}$ to be valid, it is essential that no overland flow be included in the streamflow. The first computation was made using chemical-quality data from samples collected on May 22.1980 . At that time, the streamflow may have included a small component of overland flow. On June 5, 1980, there was no snowpack and overland flow was nil. Thus, computations of $Q_{B}$ and $Q_{F}$ probably are most valid beginning with the measurements made in June.

The computed values of $Q_{F}$ and $Q_{B}$ are shown in figure 13 for Coal, Soldier and Dugout Creeks. As the hydrographs indicate, the ground-water contribution is greatest during the early part of the recession period. The streamflow during the early part of the recession period consists mostly of $Q_{F}$; but by late summer or early fall, $Q_{F}$ has receded more than $Q_{B}$. At Soldier and Coal Creeks, $Q_{B}$ sustains the low flow through the fall. At Dugout Creek, $Q_{F}$ is slightly greater than $Q_{B}$ during the early fall and streamflow has almost ceased.

The estimated proportions of ground water and surface runoff from Coal, Soldier, and Dugout Creeks during the 1980 water year are shown in table 10 . Groundwater discharge from the Flagstaff Limestone contributed about 4,400 acre-feet, or 41 percent of the combined streamflow of Coal, Soldier, and Dugout Creeks; discharge from the Blackhawk and other formations contributed about 2,200 acre-feet, or 21 percent of the streamflow.

\section{DETECTING EFFECTS OF MINING ON THE HYDROLOGY}

Several methods were used in this study to provide an understanding of the relationship between ground and surface water. Combinations of some of these methods can be used to determine if hydrologic changes that occur during mining are caused by interbasin diversions or by redistribution of flow along streams within a basin.

The drainage basin of Mud Creek currently (1981) is the most active mining area in the Wasatch Plateau.
The possibility exists of diverting ground water from the Mud Creek basin into Huntington Creek by means of underground tunneling associated with mining activities.

\section{Interbasin Diversions}

If the low flow of a stream is affected by interbasin diversion of ground water, this can be determined by correlation with low flows of streams in adjacent basins where geology and climate are similar. Waddell and others (1981, fig. 10) correlated the low flows of several streams in the southern Wasatch Plateau. They found that with 5 years of continuous-discharge record, monthly flows during August, September, and October could be estimated with a standard error of 20 percent.

The length of the discharge records at Mud Creek and Eccles Canyon are too short to make correlations between monthly flows. The ratios of the monthly flows of Mud Creek (site S36) to Fish Creek (site S2) were computed to determine their agreement for 1979 and 1980. The ratios of monthly flows for October ranged from 0.39 to 0.45 , for August the ratios ranged from 0.19 to 0.34 , and for September they ranged from 0.22 to 0.38 . Precipitation and streamflow were much greater during 1980 than during 1979, so the ratios provide some indication of how good the correlation is for variable climatic conditions.

The volume of water that would have to be diverted from the Mud Creek basin before it could be detected can be approximated by assuming that the standard error of estimate is similar to that obtained by Waddell and others (1981, p. 13), and by using the average flow ratio of 0.42 between Mud and Fish Creeks for October. Using (1) a standard error of 20 percent, (2) an average flow at Fish Creek at site S2 during October of 330 acre-feet, and (3) the ratio of flow in Mud Creek to Fish Creek of 0.42 , then the standard error of estimate of the flow in October in Mud Creek would be $( \pm 0.20)$ (330) $(0.42)= \pm 28$ acre-feet (or an average flow of \pm 0.45 cubic foot per second). If the diverted volume were equal to 0.45 cubic foot per second, it would be detectable two-thirds of the time by using the correlation between the flows of Mud and Fish Creek.

In the Book Cliffs, it is not likely that water will be diverted out of the Price River basin, but diversions may occur within subbasins. The lengths of the discharge records at Coal, Soldier, Dugout, Grassy Trail, and Horse Canyon Creeks are too short to make correlations between monthly flows. The records at these stations were correlated with the long-term record at Willow Creek (site S37.3). The computed ratios indicate that correlation with Willow Creek may be poor, probably due to thunderstorms in late August and September, which are generally localized and of variable intensity. 


\section{Redistribution of Flow}

Mining activities may affect the distribution of flow along stream reaches by direct interception of water from a stream or by interception of ground water that is percolating to the stream. In several of the potential coal-development areas, including the Mud and Soldier Creek drainages, gaging stations are operated downstream from the existing or potential coal-mining areas. In addition, seepage-study sites extend from upstream of the coalmining areas to the gages. Correlation ratios for flows at seepage-study sites and at gaging stations may prove useful on some streams for detecting changes in the distribution of flow along stream reaches.

Ratios were computed between the gaged flow and the base flows at sites upstream and downstream from existing or potential coal-mining areas for the Mud and Soldier Creek drainages. The ratios. which were computed for seepage studies made in 1979 and 1980 . are shown in figures 22, 23, and 24 .

The ratios for flows along Mud Creek were fairly uniform in the upstream reaches but varied considerably in the downstream reaches (fig. 22). The maximum range in ratios at sites upstream from Boardinghouse Canyon was 16 percent for as many as four measurements made during August, September, and October in 1979 and 1980. Downstream from Boardinghouse Canyon, the range was 32 percent. By eliminating the August 1980 measurement, the maximum range in ratios for all sites on Mud Creek is decreased to about 20 percent. Considering that the distribution of flow along Mud Creek has been affected by past mining and that the base flows are comprised of inflow from both the Blackhawk Formation and the Star Point Sandstone, the ratios are within a small enough range to provide a means of detecting changes caused by future mining activities. Future monitoring probably needs to be confined to the base-flow period of September and October.

The ratios computed for Eccles Canyon were consistent during 1979 and 1980 (fig. 23) despite the large difference in the quantity of base flow during the 2 years (fig. 16). The maximum difference was about 12 percent of the gaged flow at site S29. This indicates that the distribution of flow along the stream is not affected by considerable differences in total ground-water discharge to the streams. This is probably because most of the base flow of Eccles Canyon during the fall is maintained by ground water from only one aquifer-the Star Point Sandstone. Changes in the ratios that might be caused by future mining activities would be due to changes in recharge or discharge to the Star Point Sandstone. Thus, if tunneling in the Blackhawk Formation in the upper part of Eccles Canyon intercepts recharge that would have percolated to the Star Point Sandstone, it probably would cause the ratio to increase in the upper part of Eccles Canyon and decrease in the lower part of the canyon.

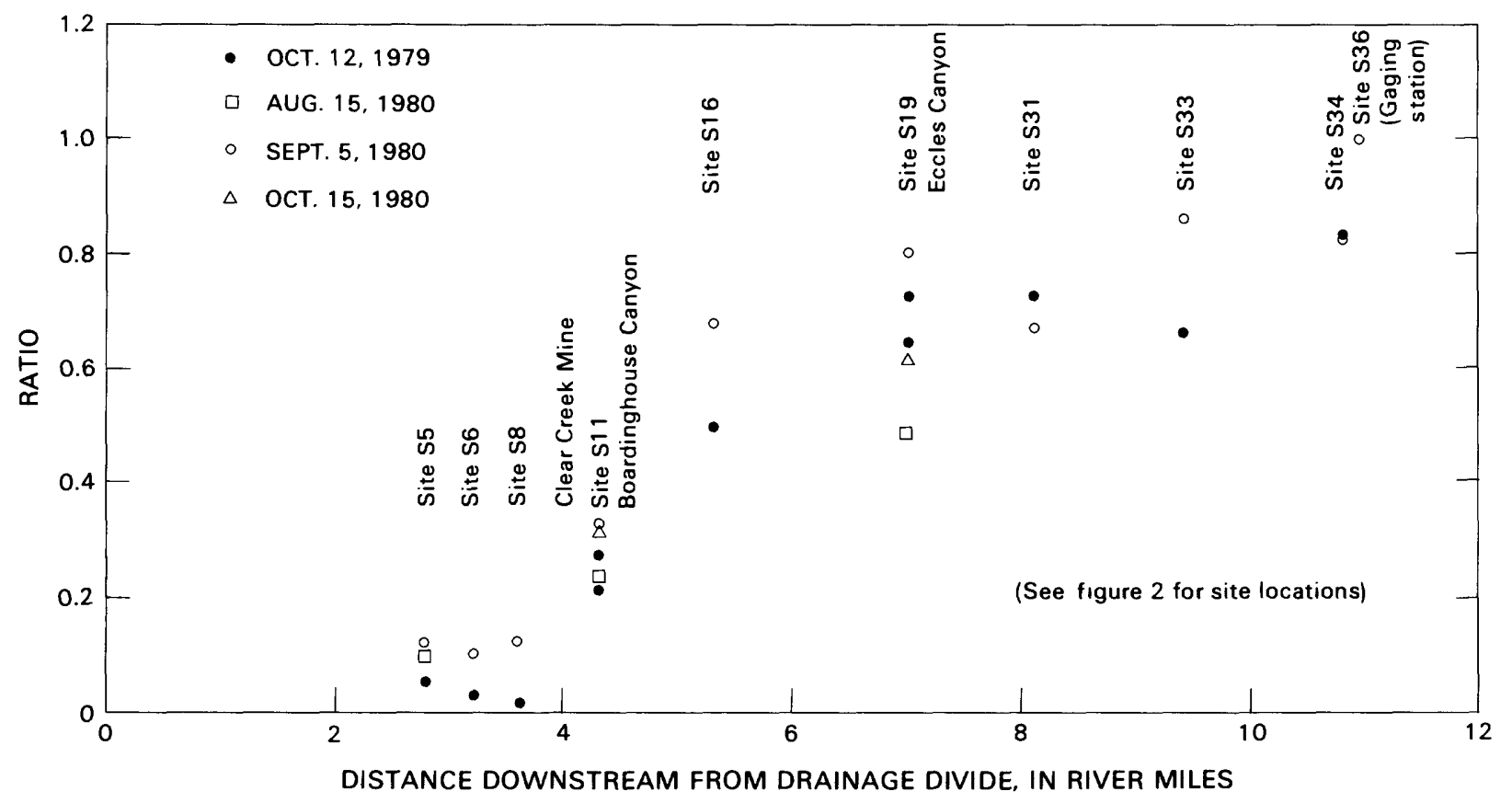

Figure 22. Ratio of discharge at selected sites to discharge at mouth of Mud Creek (site S36) on October 12, 1979, August 15, 1980, September 15, 1980, and October 15, 1980. 
The ratios computed for Soldier Creek (fig. 24) are affected by the volume of water being contributed by the Flagstaff Limestone relative to the contributions of underlying formations. Downstream from site S39, the ratios during August are smaller than the September ratios, and the ratios during September mostly are smaller than the ratios during October. Downstream from site S39. the base flow is a mixture of water from the Flagstaff and underlying formations. As discussed in the section on "Discharge to streams," the proportion of water contributed by the Flagstaff at the gaged site (S59) is much smaller during the fall than during the summer after snowmelt, whereas the seasonal change in the volume of ground water contributed by the Blackhawk and other formations is comparatively small. Thus, to decrease the variability of the ratios, measurements need to be made during late September or in October when the contribution from the Flagstaff Limestone is small. The use of ratios based on measurements made during September and October would not be effective in detecting changes in the contribution from the Flagstaff, however, because only a small volume of water is contributed by the Flagstaff during September and October.

\section{ADDITIONAL STUDIES}

1. In order to detect the effects of interbasin diversion of ground water and redistribution of streamflow, monitoring needs to include continuous gaging of stream-

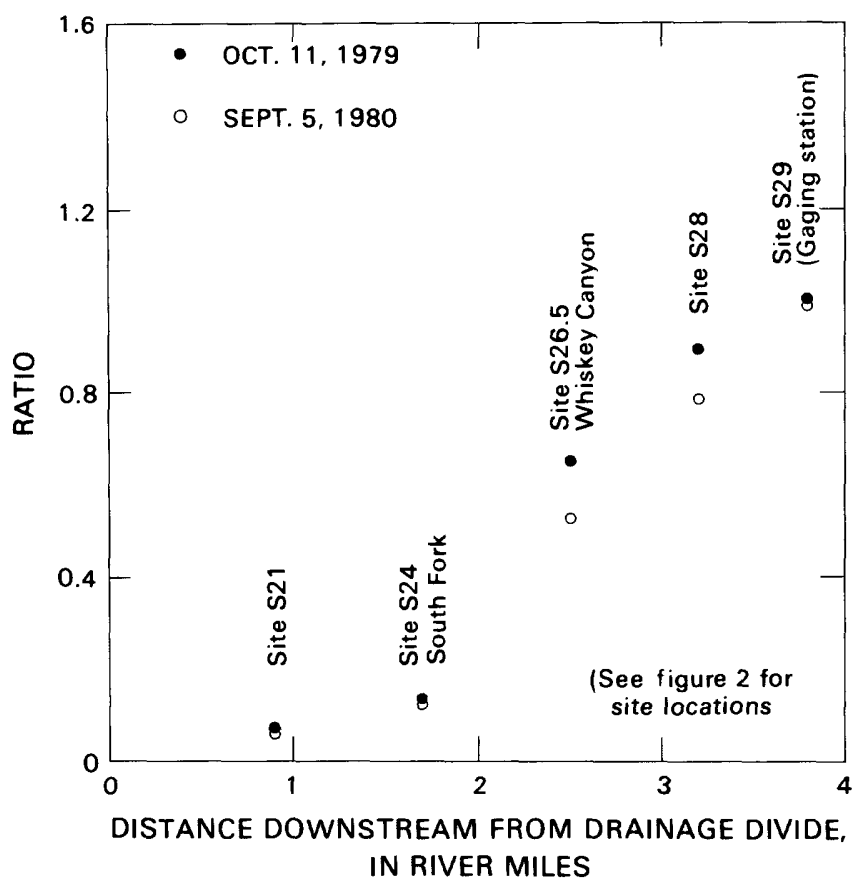

Figure 23. Ratio of discharge at selected sites to discharge at mouth of Eccles Canyon (site S29) on October 11, 1979, and September 5, 1980.

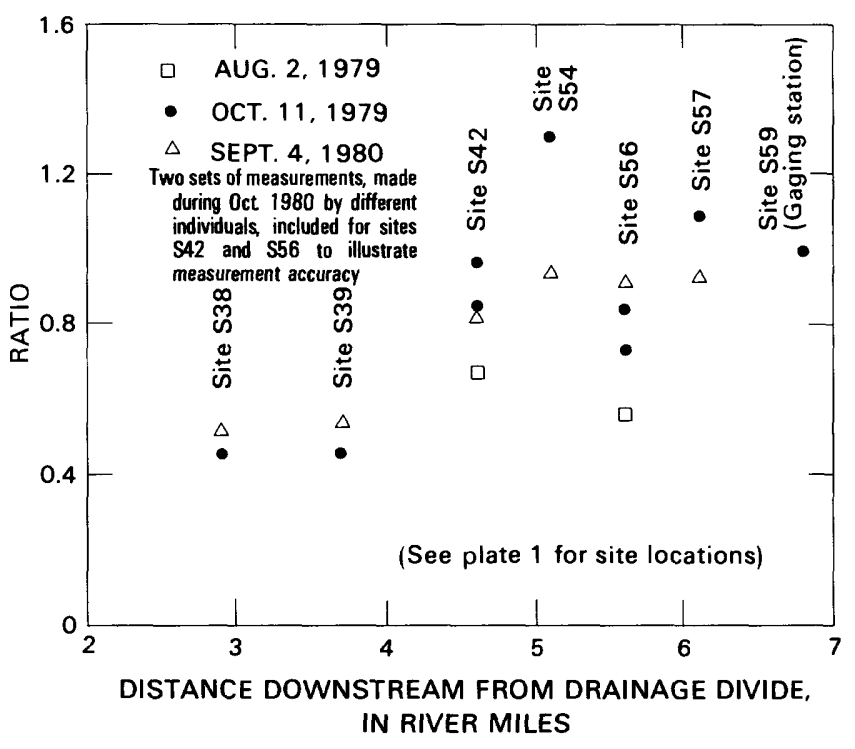

Figure 24. Ratio of discharge at selected sites to discharge at mouth of Soldier Creek (site S59) on August 2, 1979, October 11, 1979, and September 4, 1980.

flow at sites directly downstream from coal-mining areas in conjunction with seepage studies in the stream reaches upstream from the gaged sites. The seepage studies need to be made during September or October. Prior to making seepage studies, gageheight charts need to be examined to determine if streamflow conditions have been affected by recent precipitation. The monthly flow of Mud Creek needs to be correlated with that of Fish Creek in order to detect possible effects of interbasin diversions.

2. The major dissolved inorganic ions need to be monitored during the recession period following snowmelt at Coal, Soldier, and Dugout Creeks. Monthly sampling needs to begin after the snowpack is gone and continue until September or October. The data obtained need to be studied to determine if groundwater contributions from the Flagstaff Limestone and Blackhawk Formation have changed as a result of mining activities.

3. The natural discharge areas of aquifers upstream and downstream from mines need to be monitored by seepage studies in streams. In addition, the flow of major springs needs to be measured at least twice monthly beginning with the snowmelt period and continuing through October so that recession characteristics can be determined.

4. The hydraulic characteristics of the Star Point Sandstone and the Blackhawk Formation need to be defined in Eccles Canyon by means of aquifer tests at existing wells completed in the Star Point and new wells to be completed in the Blackhawk.

5. In order to define the direction of ground-water movement in the Wasatch Plateau, hydraulic-head 
differences with depth need to be determined in the recharge and discharge areas of Eccles Canyon as well as in all basins where there is or will be mining. In the Book Cliffs, hydraulic-head differences with depth need to be defined near the face of the cliffs and at sites some distance into the cliffs; zones in the Flagstaff Limestone, North Horn, and Price River Formations, Castlegate Sandstone, and Blackhawk Formation need to be included. Additional information about the direction of ground-water movement in the Book Cliffs could be obtained by determining the redox potential of water using selected phases of nitrogen, $\mathrm{pH}$, and trace metals, and the concentrations of sulfide and sulfate in water from spring G89, wells G84.5 and G58.5. and from mines at sites G98.5 and G99.7.

6. Sediment concentration needs to be monitored in Eccles Canyon. Data collection needs to include thunderstorm runoff as well as snowmelt runoff, and sufficient data need to be collected so that total sediment loads can be computed.

7. In order to detect the possibility of increasing productivity of algae and other plants in Scofield Reservoir, nutrients need to be monitored in Mud Creek and in the outflow from the reservoir.

\section{SUMMARY}

1. The flow of Fish Creek in the Wasatch Plateau was about 97 percent of the average for the 1971-80 water years during 1979 and about 170 percent of the average during 1980. Willow Creek in the Book Cliffs was about 250 percent of the average for the 1971-80 water years during 1979 and about 196 percent of the 1971-80 average during 1980.

2. Estimated annual evapotranspiration during the 1971-80 water years in four basins in the Wasatch Plateau and Book Cliffs ranged from 16 to 21 inches and averaged 19 inches.

3. During the 1980 water year, the concentration of dissolved solids at the gage on Mud Creek in the Wasatch Plateau ranged from 150 milligrams per liter during high flow to 390 milligrams per liter during low flow, and the discharge-weighted average was 216 milligrams per liter. The principal chemical constituents were calcium and bicarbonate during all flows. Eccles Canyon is a major contributor of nutrients to Mud Creek, and most of the nutrient load occurs in the form of suspended organics. During the snowmelt period, total nitrogen and phosphorus were as great as 21 and 4.3 milligrams per liter at the gaging station in Eccles Canyon.

4. During the 1980 water year, the concentration of dissolved solids in Soldier Creek at the gaging station in the Book Cliffs ranged from 277 milligrams per liter during high flow to 696 milligrams per liter during low flow. The principal chemical constituents in the high flows following snowmelt are calcium and bicarbonate, whereas in the low flows they are sodium, magnesium, sulfate, and bicarbonate. Streamflow after snowmelt consists principally of ground water from the Flagstaff Limestone, whereas during the late summer and fall the streamflow generally consists of relatively greater proportions of ground water from the Blackhawk and other formations. Coal and Dugout Creeks have waterquality characteristics similar to that of Soldier Creek.

5. During the early fall of 1979 Scofield Reservoir was almost completely mixed due to the autumn turnover. In August 1980, however, the reservoir was stratified and an anaerobic zone had developed in the deeper part of the reservoir.

6. Most of the deposition of coal in Scofield Reservoir occurred prior to about 1950 . The concentrations of trace metals such as iron, manganese, lead, and zinc are enriched near the surface of the bottom sediments, but the enrichment is not as pronounced for the other metals, including arsenic and mercury.

7. Deposition of sediment in Scofield Reservoir during 1943-79, as determined from bathymetric surveys, was computed to be 3,000 acre-feet. The average sediment yield of the associated drainage basin, as determined from bathymetric surveys and dating with radioisotopes, ranged from 0.2 to 0.5 acre-foot per square mile per year.

8. Much of the ground-water discharge from the Star Point Sandstone and the Mesaverde Group in the Wasatch Plateau occurs along faults. In the Book Cliffs, where faulting is less extensive, most of the ground-water discharge is from the Flagstaff Limestone. The Flagstaff has great diffusivity, has a small storage coefficient, and contains water which is perched.

9. Springs issuing from the Star Point Sandstone in the Mud Creek drainage basin typically had recession indexes greater than 365 days per log cycle. Springs issuing at the higher altitudes from the Colton Formation and the Flagstaff Limestone in the Soldier Creek area, have greater seasonal variability, with recession indexes ranging from 24 to 115 days per log cycle.

10. During 1980, the total reported and measured mine discharge in the study area was 2,800 acre-feet.

11. In the Book Cliffs, recession characteristics of streamflow may have some use in monitoring possible changes in recharge to and discharge from the Flagstaff Limestone. Subsidence could cause a change in the recharge-discharge relationships.

12. In most of the Wasatch Plateau, the concentration of dissolved solids in ground water was less than 
500 milligrams per liter, and the principal chemical constituents were calcium and bicarbonate. In the Book Cliffs, the concentration of dissolved solids in water in the Flagstaff Limestone ranged from 250 to 500 milligrams per liter, whereas in water from the Blackhawk and North Horn Formations, the concentration ranged from 500 to more than 1,000 milligrams per liter. The principal chemical constituents in water from the Flagstaff Limestone were calcium and bicarbonate, but water from the Blackhawk was of variable chemical composition, generally of a mixed type with no dominant cation or anion. In areas of the Book Cliffs where the Mancos Shale is affecting the quality of water in the Blackhawk Formation, sodium and sulfate ions generally dominate the chemical composition. Most ground water in the study area is almost saturated with respect to calcite.

13. The top of the saturated zone in the Blackhawk Formation in the upper part of Eccles Canyon generally is above the coal zones, and dewatering will be required in most places during mining.

14. In Eccles Canyon in the Wasatch Plateau seepage from the Star Point Sandstone is the major contributor to base flow. During the fall of 1980, gains of as much as 230 gallons per minute occurred near a fault zone which crosses Eccles Canyon at the junction with South Fork Canyon.

15. Prior mining has caused redistribution of flow in the upper Mud Creek drainage basin. Water from Mud Creek that is intercepted by the abandoned Clear Creek Mine is discharged back to Mud Creek downstream from the mine.

16. During the 1980 water year, the estimated annual discharge from the major springs and mines issuing from the Blackhawk Formation and Star Point Sandstone in the Mud Creek drainage basin was 1,340 acre-feet.

17. Estimated tranmissivities in the Soldier Creek area ranged from 0.07 foot squared per day in the Price River Formation to 0.003 foot squared per day in a lower zone of the Castlegate Sandstone.

18. In both the Mud Creek drainage basin and the Soldier Creek area, the coal-bearing zones of the Blackhawk Formation are saturated with water, and in most places dewatering will be required during mining.

\section{REFERENCES CITED}

Ayling, G.M., 1974. Uptake of cadmium, zinc, copper, lead, and chromium in the Pacific oyster, Crassostrea gigas, grown in the Tamar River, Tasmania: Water Research, v. 8 , p. $729-738$.
Ball, J.W., Norstrom, D.K., Jenne, E.A., 1980, Additional and revised thermochemical data and computer code for WateQ2-A computerized model for trace and major element speciation and mineral equilibria of natural waters: U.S. Geological Survey Water-Resources Investigations 78-116, $109 \mathrm{p}$.

Bryan, G.W., and Hummerstone, L.G., 1973, Adaptation of the polycheata Nereis diversicolor to manganese in estuarine sediment: Journal of the Marine Biological Association of the United Kingdom, v. 53, p. 859-872.

Cooper, H.H., Jr., Bredehoeft, J.D., and Papadopulos, I.S., 1967, Response of a finite-diameter well to an instantaneous discharge of water: Water Resources Research, v. 3, no. 1, p. 263-269.

Cordova, R.M., 1963, Hydrogeologic reconnaissance of part of the headwaters area of the Price River, Utah: Utah Geological and Mineralogical Survey Water-Resources Bulletin 4, $26 \mathrm{p}$.

Guy, H.P., 1969, Laboratory theory and methods for sediment analysis: U.S. Geological Survey, Tecniques of WaterResources Investigations, Book 5, Chapter C1, 58 p.

Hutchinson, G.E., 1957, Geography, physics, and chemistry, Volume 1-A treatise on limnology: New York, John Wiley, $1015 \mathrm{p}$.

Lines, G.C., and Plantz, G.G., 1981, Hydrologic monitoring in coal fields of central Utah, August 1978-September 1979: U.S. Geological Survey Water-Resources Investigations 81-138, 56 p.

Lium, B.W., 1974, Some aspects of aquatic insect populations of pools and riffles in gravel bed streams in western United States: U.S. Geological Survey Journal of Research, v. 2 , no. 3 , p. 382.

Miller, J.F., Frederick, R.H., and Tracey, R.J., 1973, Precipitation-frequency atlas of the western United States, Volume VI-Utah: National Oceanic and Atmospheric Administration NOAA Atlas 2,67 p.

Mundorff, J.C., 1972, Reconnaissance of chemical quality of surface water and fluvial sediment in the Price River basin, Utah: Utah Department of Natural Resources Technical Publication 39, 55 p.

Ponce, S.L., and Hawkins, R.H., 1978. Salt pickup by overland flow in the Price River basin, Utah: American Water Resources Association, Water Resources Bulletin, v. 14, no. 5. p. 1187-1200.

Riggs, H.C., 1964, The base-flow recession curve as an indicator of ground water: International Association of Scientific Hydrology Publication 63, p. 352-363.

Rorabaugh, M.I., 1960, Use of water levels in estimating aquifer constants in a finite aquifer: International Association of Science Hydrology Publication 52, p. 314-323.

1964 , Estimating changes in bank storage as groundwater contribution to streamflow: International Association of Science Hydrology Publication 63, p. 432-441.

Rorabaugh, M.I., and Simons, W.D., 1966, Exploration of methods of relating ground water to surface water. Columbia River basin-Second phase: U.S. Geological Survey Open-File Report, $62 \mathrm{p}$. 
Shultz, L.G., 1964, Quantitative interpretation of mineralogical composition from X-ray and chemical data from the Pierre Shale: U.S. Geological Survey Professional Paper 391-C. $31 \mathrm{p}$.

Skei, Jens, and Paus, P.E., 1978, Surface metal enrichment and partitioning of metals in a dated sediment core from a Norwegian fjord: Geochimica et Cosmochimica Acta v. 43, p. 239-246.

Spieker, E.M., 1931, The Wasatch Plateau coal field Utah: U.S. Geological Survey Bulletin 819, 210 p.

Stiff, H.A., Jr., 1951, The interpretation of chemical water analysis by means of patterns: Journal of Petroleum Techniques, Technical Note 84 , p. 15-17.

Stokes, W.L., ed., 1964, Geologic map of Utah: University of Utah, scale 1:250,000.

Thomas, B.E., and Lindskov, K.L.. 1983, Methods for estimating peak discharge and flood boundaries of streams in Utah: U.S. Geological Survey Water-Resources Investigations 83-4129, $77 \mathrm{p}$.

Trainer, F.W., and Watkins, F.A., Jr., 1974, Use of base-runoff recession curves to determine areal transmissivity in the upper Potomac River basin: U.S. Geological Survey Journal of Research, v. 2, no. 1, p. 125-131.

U.S. Department of Agriculture, 1973, Estimating sediment yield rates for the State of Utah: Western United States water-plan map, scale 1:500,000.
U.S. Environmental Protection Agency, Environmental Studies Board, 1976, National interim primary drinking water regulations: Washington, U.S. Government Printing Office, $159 \mathrm{p}$.

1978, Quality criteria for water: Washington, U.S. Government Printing Office, 256 p.

U.S. Geological Survey, 1979, Development of coal resources in central Utah: Final environmental statement, Regional analysis Part 1, page I-11.

1980, Water Resources Data for Utah, water year 1980: Water-Data Report UT 80-1, 684 p.

U.S. Weather Bureau, 1963, Normal annual and May-September precipitation (1931-60) for the State of Utah: Map of Utah, scale $1: 500,000$.

Waddell, K.M., Dodge, J.E., Darby, D.W., and Theobald, S.M., 1982, Selected hydrologic data 1978-80, Price River basin, Utah: U.S. Geological Survey Open-File Report 82-916 (also duplicated as Utah Hydrologic-Data Report 38), 72 p.

Waddell, K.M., Sumsion, C.T., Butler, J.R., and Contratto, P.K., 1981, Hydrologic reconnaissance of the Wasatch PlateauBook Cliffs coal-fields area: U.S. Geological Survey WaterSupply Paper 2068, 45 p.

Waddell, K.M., Vickers, H.L., Upton, R.T., and Contratto, P.K., 1978, Selected hydrologic data, Wasatch Plateau-Book Cliffs coal-fields area, Utah: U.S. Geological Survey OpenFile Report 78-121 (also duplicated as Utah Basic-Data Release 31), 33 p. 
DEPARTMENT OF THE NTERIOR
U.S. GEOLOOCICALL SURVEY

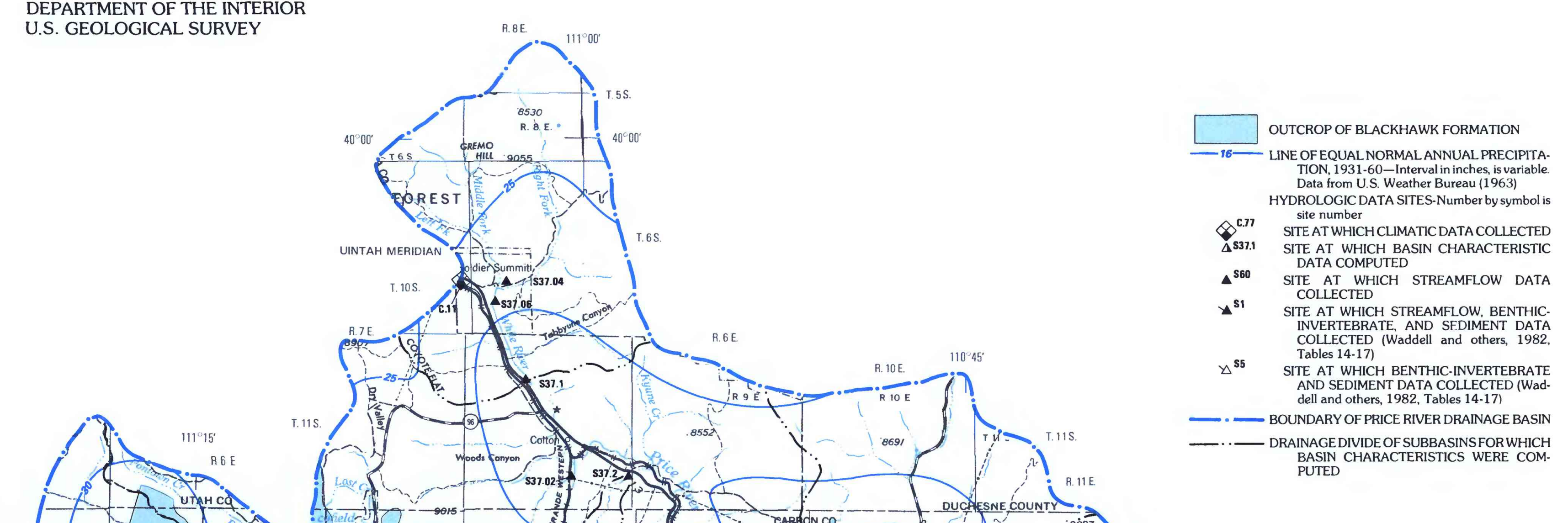

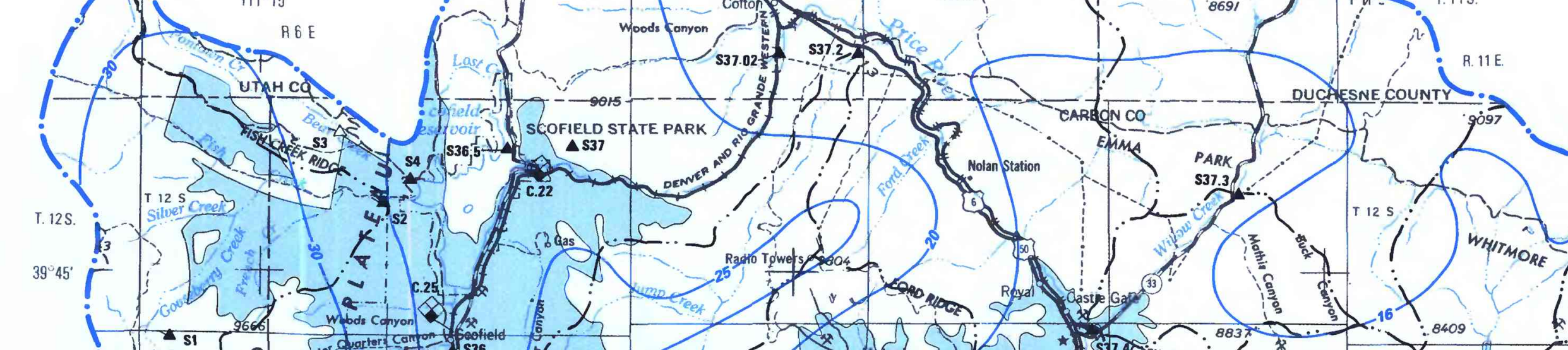

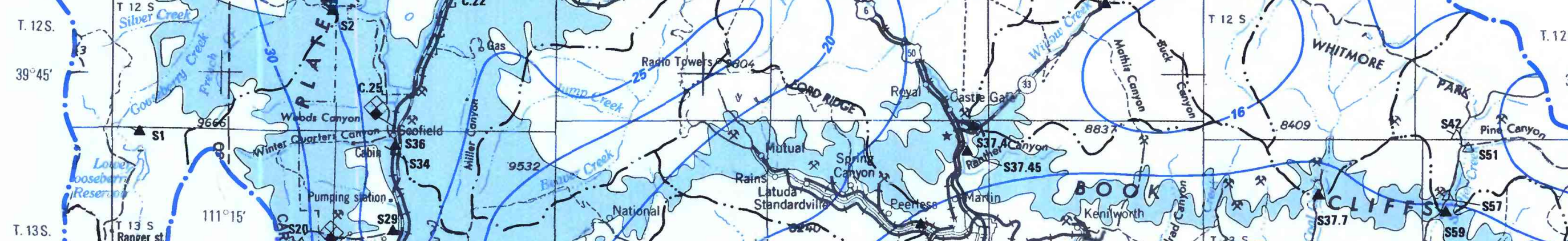

'wh $h=1+\cdots$

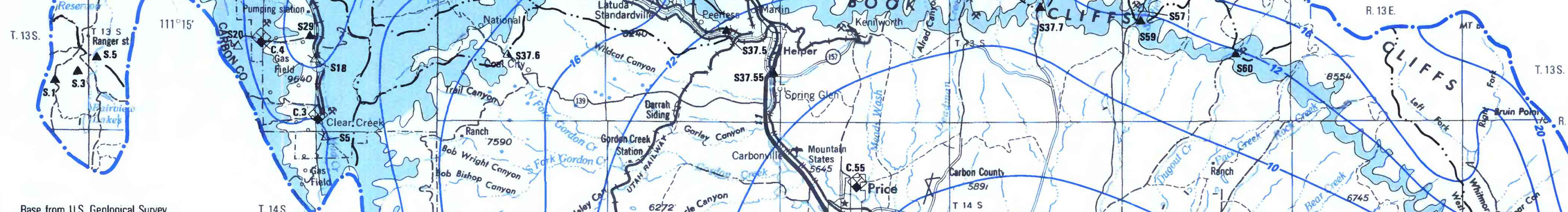

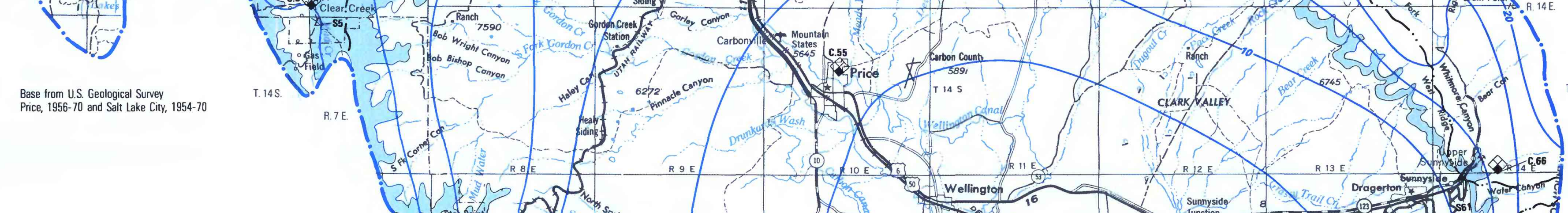

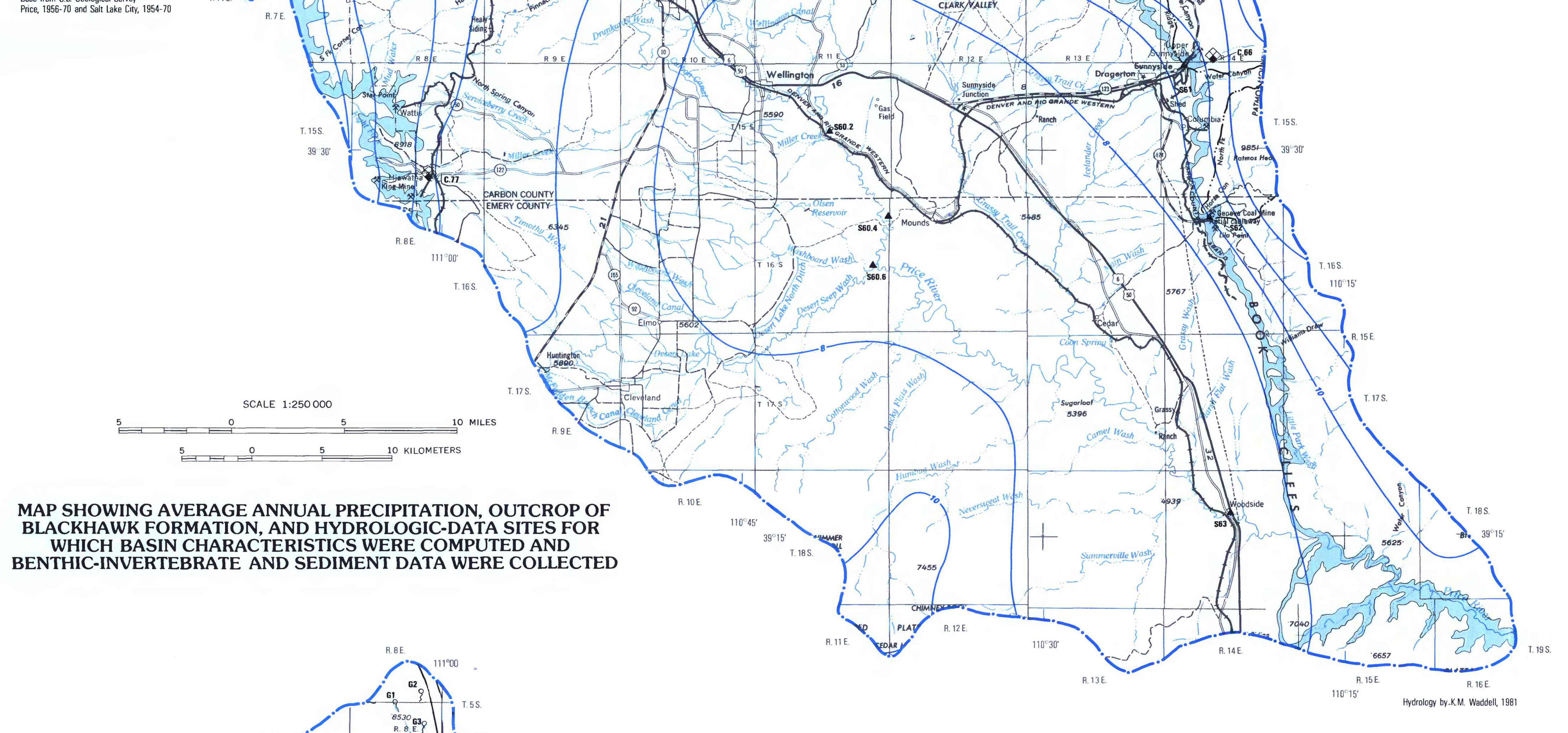

TENTRATION OF DISSOLVED SOLIS

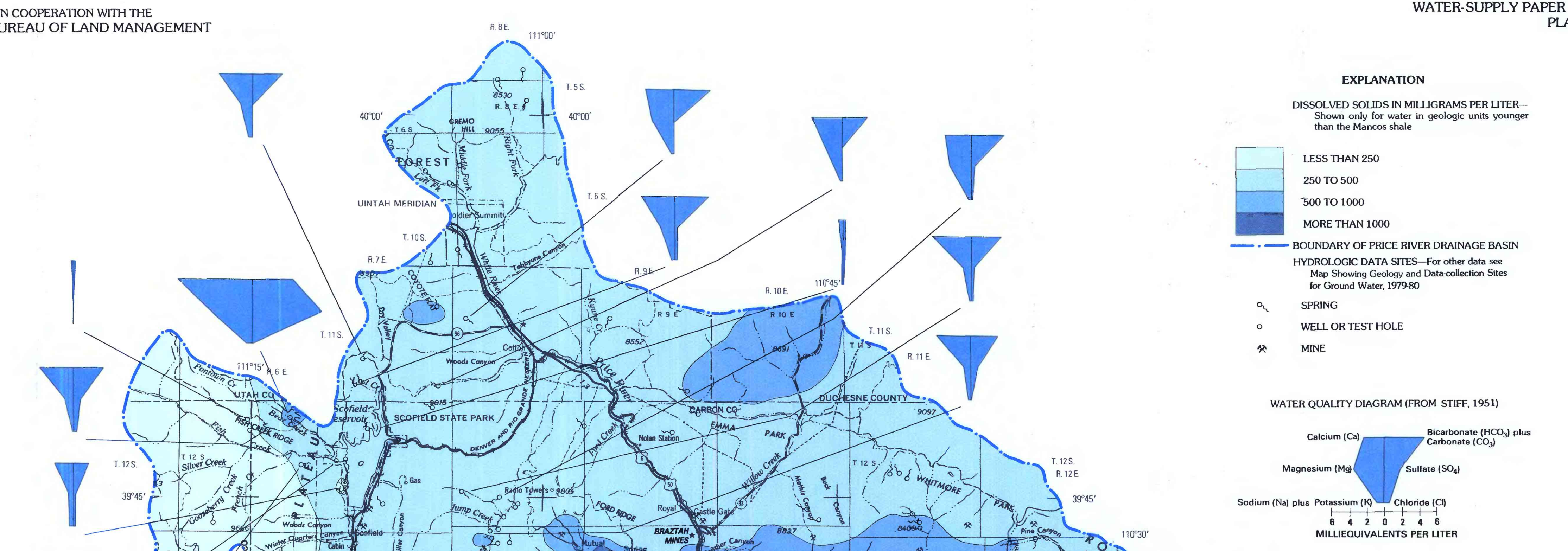

10 .

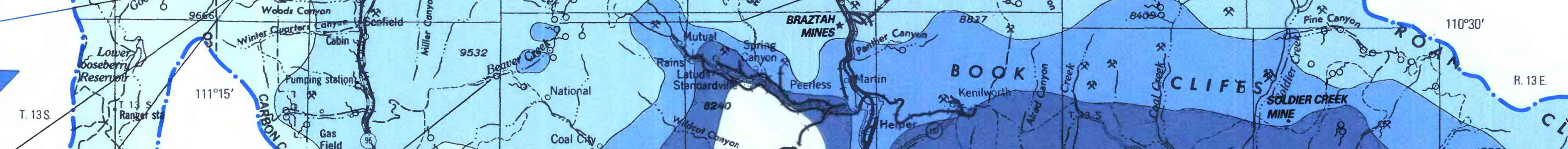

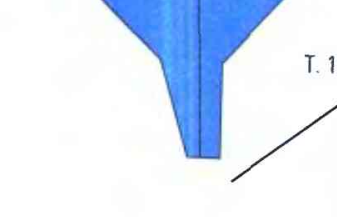
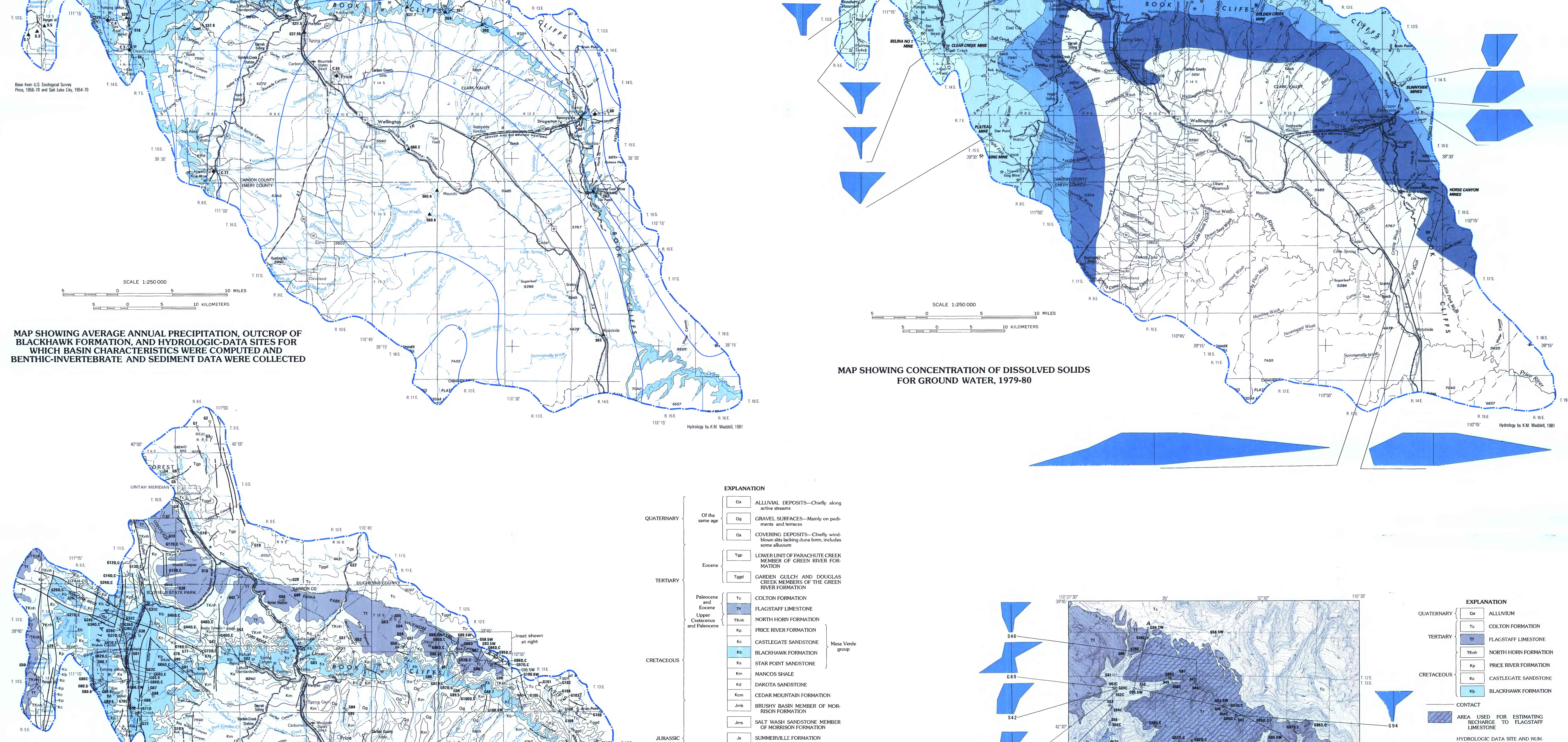

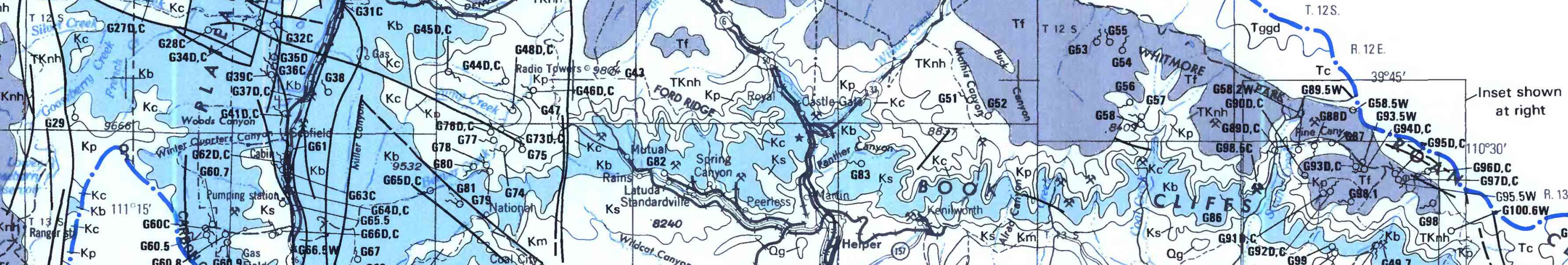

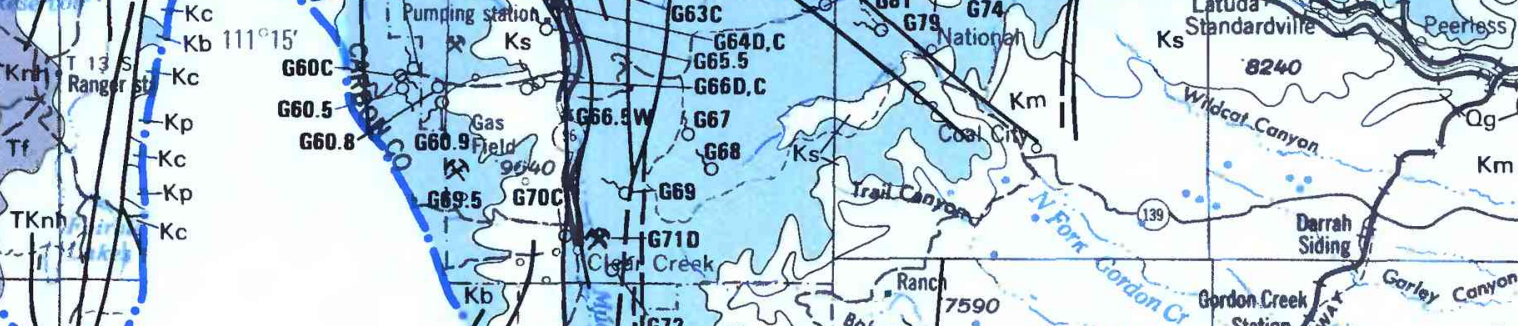

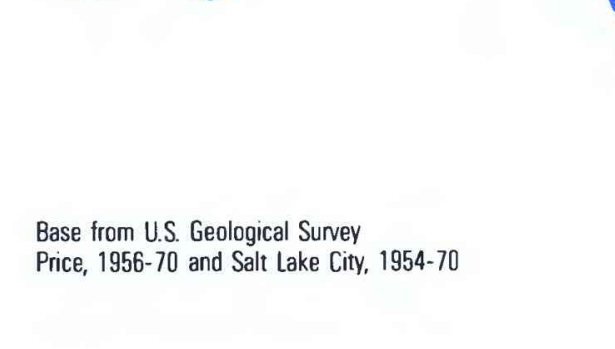

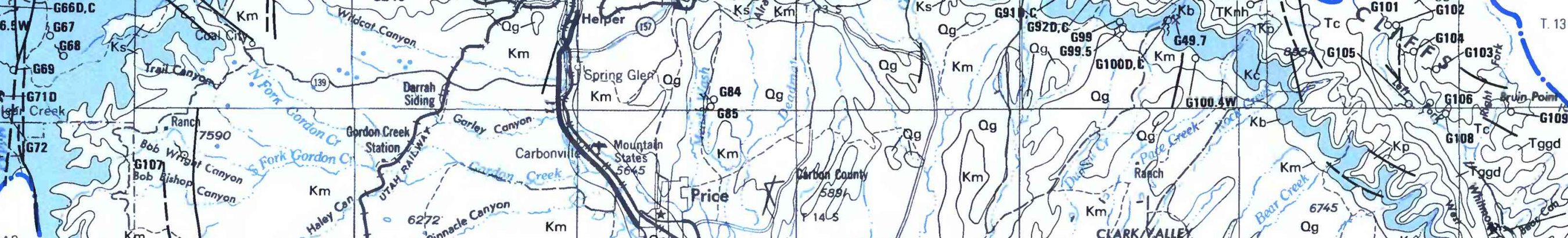

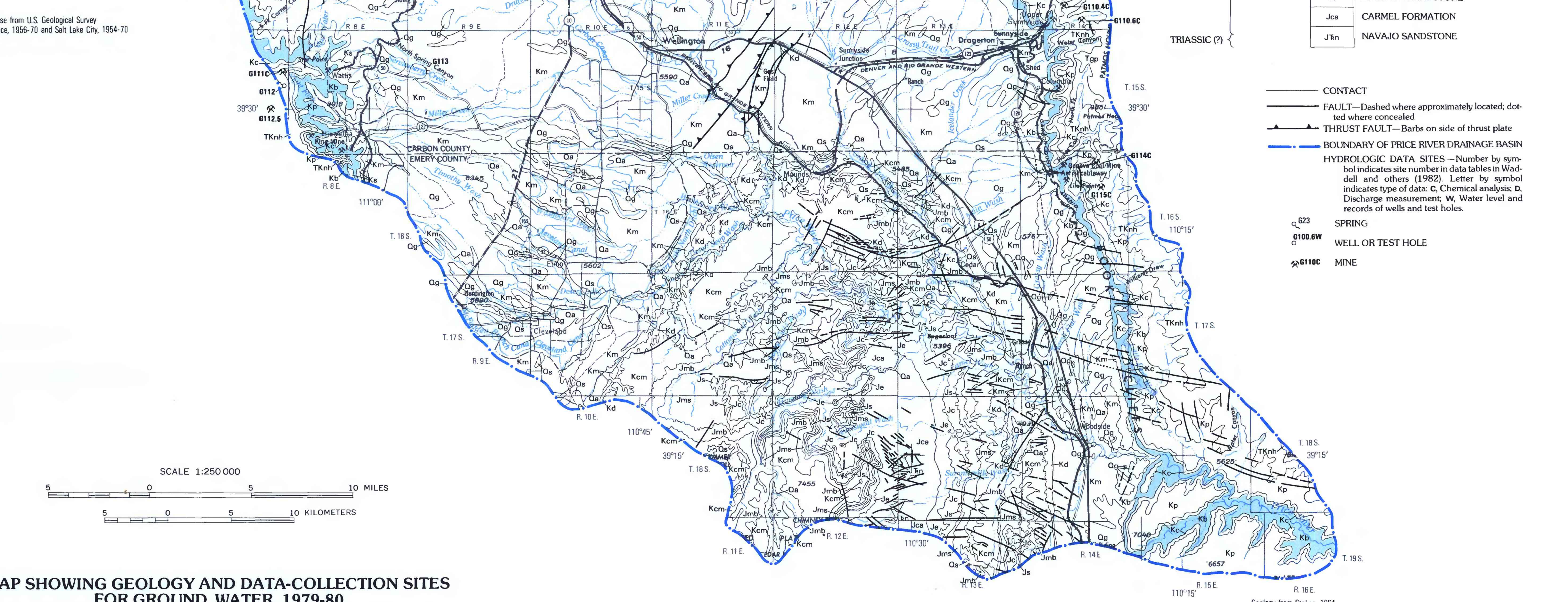

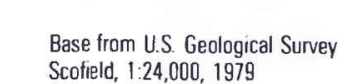

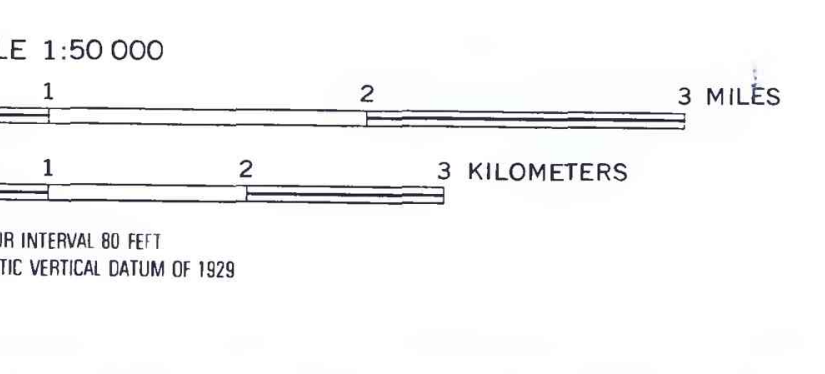

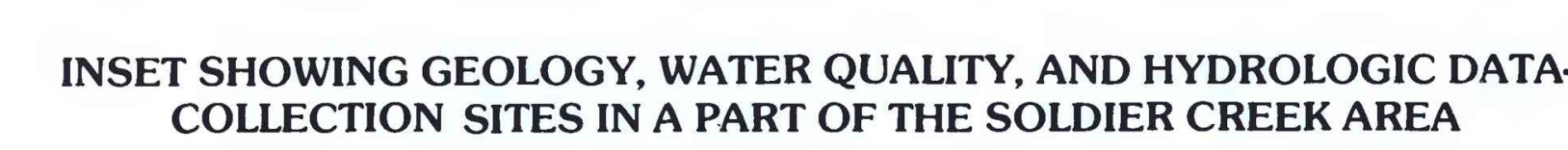

MAPS SHOWING GEOLOGY, AVERAGE ANNUAL PRECIPTATION, CONCENTRATION OF DISOLLED SOLDS IN GROUND WATER,

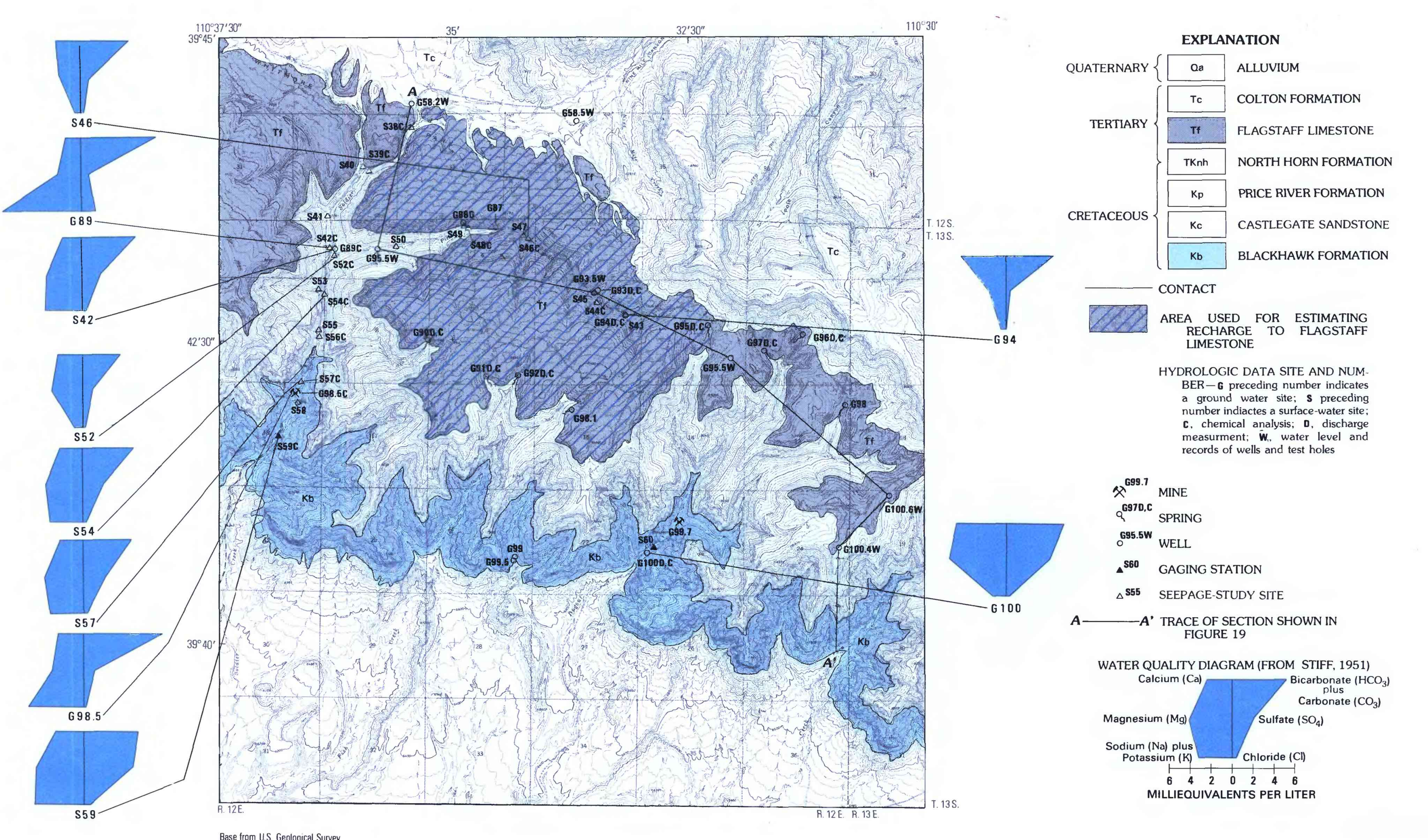

